CLAUDIA REGINA SERANTONI DA SILVA

\title{
FADIGA TÉRMICA DE FERROS FUNDIDOS BRANCOS
}

MULTICOMPONENTES

Dissertação apresentada à Escola

Politécnica da Universidade de São Paulo para obtenção do

Título de Mestre em Engenharia 


\section{CLAUDIA REGINA SERANTONI DA SILVA}

\section{FADIGA TÉRMICA DE FERROS FUNDIDOS BRANCOS}

\section{MULTICOMPONENTES}

Dissertação apresentada à Escola Politécnica da Universidade de São Paulo para obtenção do Título de Mestre em Engenharia

Área de Concentração. Engenharia Metalúrgica

Orientador: Prof. Dr. Mário Boccalini Jr. 
Ao meu marido Gustavo, pelo amor e companheirismo.

A minha mãe Dolores, pela confiança e apoio incondicionais. 


\section{AGRADECIMENTOS}

Ao meu orientador Prof. Dr. Mário Boccalini Jr., que há quatro anos vem contribuindo de forma inestimável ao meu desenvolvimento, por confiar em meu trabalho, pelo incentivo permanente e, acima de tudo, pela paciência na orientação.

A todos do Laboratório de Fenômenos da Superfície (LFS) do Departamento de Engenharia Mecânica, pelas discussões e por permitir o acesso ao uso de equipamentos e, em especial, aos colegas Eleir Bortoleto e Felipe Bernardes, pela valiosa contribuição à realização deste trabalho.

A todos os colegas da Divisão de Metalurgia do IPT, e especialmente aos amigos Leandro de Lacerda e Alzira V. O. Corrêa, pelo companheirismo e colaboração inestimável à execução deste trabalho.

Ao Prof. Dr. Hélio Goldenstein, por me orientar no início deste trabalho e pela disponibilidade em fornecer sugestões durante sua execução.

À Fundação de Amparo à Pesquisa do Estado de São Paulo - FAPESP, pelo suporte financeiro à realização deste trabalho (Auxílio à Pesquisa - processo 2001/05722-7 e Bolsa de mestrado - processo 01/00863-1).

À Villares/Sidenor - Unidade Cilindros, pelo suporte financeiro à realização deste trabalho ao final da bolsa FAPESP de mestrado. 
LISTA DE FIGURAS

\section{SUMÁRIO}

LISTA DE TABELAS

LISTA DE ABREVIATURAS E SIGLAS

LISTA DE SÍMBOLOS

RESUMO

ABSTRACT

1 INTRODUÇÃO 1

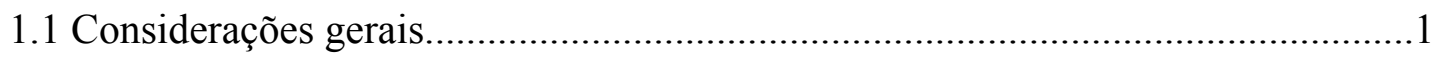

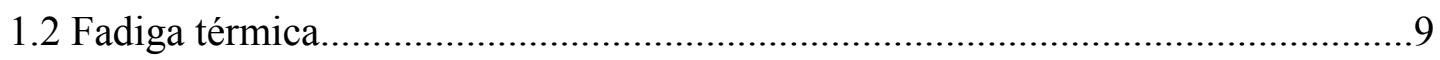

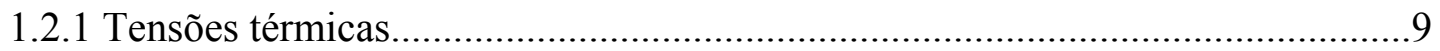

1.2.2 Trincas causadas por fadiga térmica - aspectos microscópicos.......................11

1.2.3 Fadiga térmica em materiais dúcteis.............................................................14

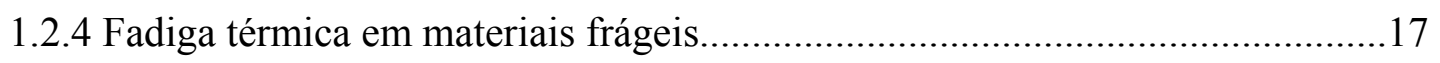

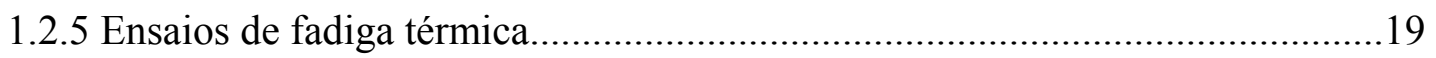

1.2.6 Correlação entre microestruturas brutas de fundição e desempenho em fadiga

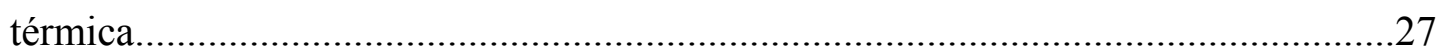

1.2.7 Fadiga térmica e microestrutura dos aços ferros fundidos brancos multicomponentes para cilindros de laminação

2 OBJETIVOS. .35

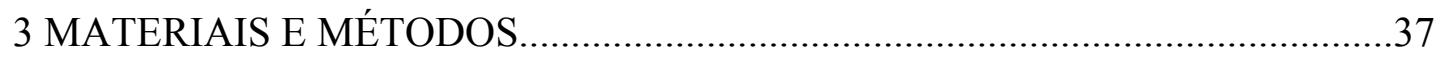

3.1 Obtenção dos corpos-de-prova para ensaio de fadiga térmica..............................37

3.2 Caracterização dos corpos-de-prova no estado inicial........................................46

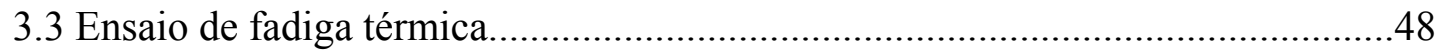

3.4 Caracterização dos corpos-de-prova no estado final..........................................50

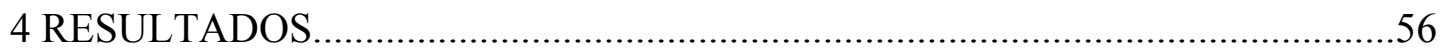

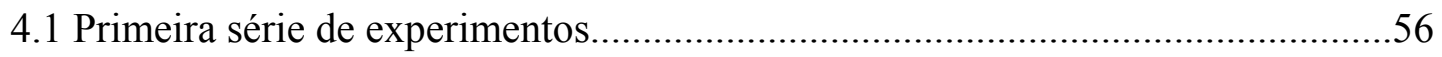

4.1.1 Caracterização dos corpos-de-prova no estado inicial......................................56

4.1.2 Caracterização dos corpos-de-prova no estado final.......................................67 
4.2 Segunda série de experimentos

4.2.1 Caracterização dos corpos-de-prova no estado inicial.....................................84

4.2.2 Caracterização dos corpos-de-prova no estado final......................................91

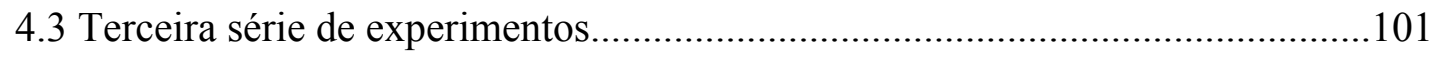

4.3.1 Caracterização dos corpos-de-prova no estado inicial....................................101

4.3.2 Caracterização dos corpos-de-prova no estado final.....................................101

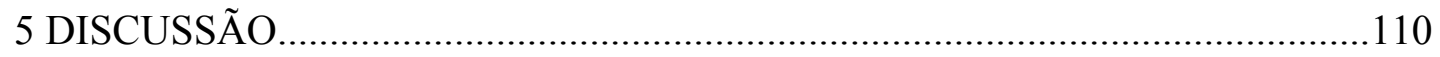

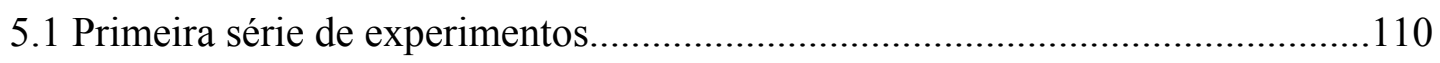

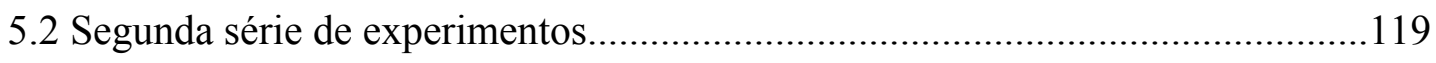

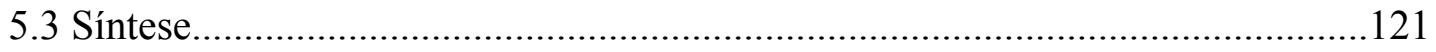

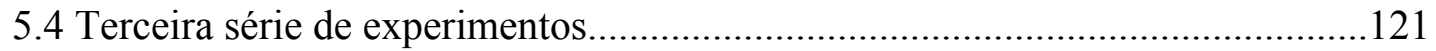

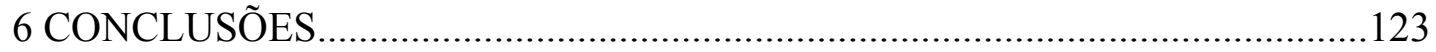

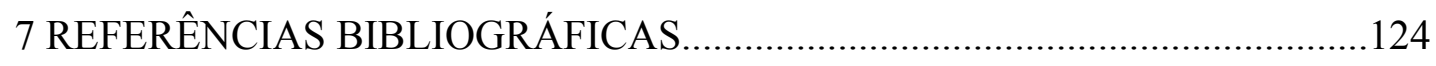




\section{LISTA DE FIGURAS}

Figura 1 - Esquema de uma linha de produção de tiras laminadas a quente. 2

Figura 2 - Variação da temperatura ao longo do raio do cilindro de trabalho na região do arco de contato durante laminação a quente $(\mathrm{Z}=$ fração do raio do cilindro;

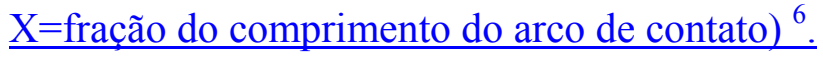
6

Figura 3- Malha de trincas térmica na superfície de cilindro de trabalho de ferro fundido branco multicomponente. Sem ataque. (100X). 7

Figura 4 - Cilindro de laminação a quente com ocorrência de "banding". 8

Figura 5- Representação esquemática do modelo de formação do "banding"

Figura 6 - Efeito do tamanho do carboneto e/ou poro sobre a vida à fadiga à temperatura ambiente da superliga MAR-M200 solidificada direcionalmente ${ }^{19}$..... 12

Figura 7 - Estágios de propagação de trinca de fadiga ${ }^{18}$. 13

Figura 8 - Diferença de temperatura mínima requerida para iniciar propagação instável de trinca em função do comprimento inicial da trinca e da densidade de trincas $^{31}$.

Figura 9 - Variação no número de ciclos para fratura de ligas a base de níquel em função da natureza do ciclo $^{34}$.

Figura 10 - Profundidade da maior trinca em função do número de ciclos para dois valores de temperatura $\mathrm{T}_{2}$ (os pontos cheios e vazios para cada temperatura representam uma repetição do ensaio) ${ }^{20}$. 
Figura 11 - Número de trincas formadas na superfície em função da variação de temperatura. (a) ferro fundido branco multicomponente, (b) ferro fundido branco alto cromo e (c) ferro fundido mesclado ${ }^{35}$.

Figura 12 - Número de ciclos para a fratura em função do tempo de permanência à temperatura máxima ${ }^{34}$ 26

Figura 13 - Influência da geometria sobre a profundidade da maior trinca em função do número de ciclos (os pontos cheios e vazios para cada temperatura representam uma repetição do ensaio). A e B - corpos-de-prova com mesmo tamanho e diferentes

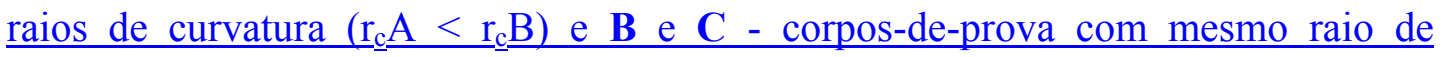
curvatura e tamanhos diferentes $(\mathrm{C}>\mathrm{B})^{20}$.

Figura 14 - Efeito do tamanho de grão sobre o número de ciclos para nuclear trinca na superliga IN-738. FG - grão fino e LG - grão grosseiro ${ }^{23} \ldots$ 29

Figura 15 - Efeito do tamanho de grão sobre a taxa de propagação de trinca da superliga IN-738. FG - grão fino e LG - grão grosseiro $^{23}$

Figura 16 - Efeito do espaçamento dendrítico no número de trincas para a fratura da liga MAR-M509 21. 30

Figura 17 - Efeito do espaçamento dendrítico na taxa inicial de propagação da trinca para a liga MAR-M509²1.

Figura 18- Microestrutura da liga Fe-7Cr-2Mo-2W-4V-1,6C. (400X). 32

Figura 19 - Relação entre o coeficiente de expansão térmica e o ponto de fusão de metais, carbonetos e boretos com estruturas compactas 9 .

Figura 20 - Geometria e dimensões finais dos corpos-de-prova para ensaio de fadiga térmica (medidas em $\mathrm{mm}$ ). 38 


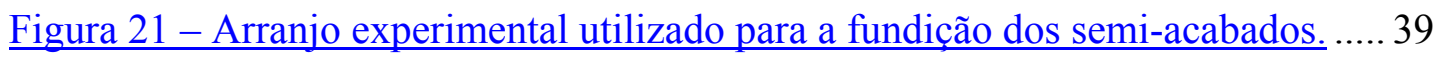

Figura 22 - Microestruturas da liga V8: (a) bruta de fundição e (b) recozida a $850^{\circ} \mathrm{C}$ por 5 horas.

Figura 23 - Esquema de corte dos semi-acabados fundidos 42

Figura 24 - Representação esquemática do ciclo de tratamento térmico a que foram submetidos os corpos-de-prova.

Figura 25 - Microestrutura da liga AM: (a) bruta de fundição e (b) pré-tratada a $1250^{\circ} \mathrm{C}-2 \mathrm{~h}$. Ataque: Villela. 43

Figura 26 - Microdureza da matriz em função da temperatura de revenimento da liga $\underline{\mathrm{V} 5}$

Figura 27 - Vista geral da máquina de fadiga térmica......

Figura 28 - Detalhe do corpo-de-prova no interior da bobina de indução (aquecimento).

Figura 29 - Representação esquemática do ciclo térmico aplicado ao corpo-de-prova durante o ensaio de fadiga térmica. 50

Figura 30 - Representação esquemática do plano de corte (a) e da seção transversal do corpo-de-prova visível após o corte (b). 51

Figura 31 - Seção transversal do corpo-de-prova após o ensaio, mostrando a divisão em quadrantes para contagem da quantidade de trincas e a "trinca passante"........... 52

Figura 32 - Representação esquemática do posicionamento do corpo-de-prova na bobina de aquecimento da máquina de fadiga térmica, mostrando (a) pista na região da mira do pirômetro óptico e (b) pista na região diametralmente oposta 
Figura 33 - Seção transversal do corpo-de-prova V5/450/100 com $30 \mathrm{~mm}$ de diâmetro, em que se observa a propagação de trinca associada a microrrechupe. MEV - elétrons secundários.

Figura 34 - Seção transversal do corpo-de-prova V6,5/450/500, em que se observa uma concentração de microrrechupes abaixo da sua superfície. MEV - elétrons secundários

Figura 35 - Detalhe da figura XX, mostrando a formação de trinca associada a microrrechupe. MEV - elétrons secundários. 55

Figura 36 - Microestrutura da liga AM, mostrando a matriz de martensita revenida e os carbonetos secundários. MEV - elétrons secundários. 56

Figura 37 - Microestrutura da liga AM. Detalhe da figura 36. MEV - elétrons secundários.

Figura 38 - Microestrutura da liga V5, mostrando a distribuição dos carbonetos $\underline{\text { eutéticos } \mathrm{MC} \text { e } \mathrm{M}_{2} \underline{\mathrm{C}} \text { : A- MC regular-complexo, B- } \mathrm{MC} \text { irregular e } \mathbf{C}-\mathrm{M}_{2}} \underline{\mathrm{C} \text { regular }}$

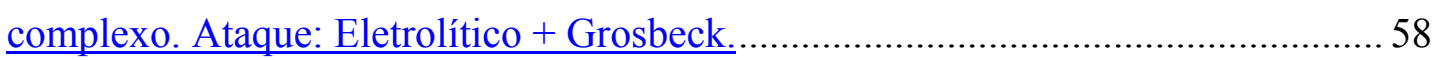

Figura 39 - Microestrutura da liga V5, mostrando detalhes dos carbonetos eutéticos $\underline{\mathrm{MC} \text { e } \mathrm{M}_{2}} \underline{\mathrm{C}}$ : A- MC regular-complexo, B- MC irregular e $\mathbf{C}-\mathrm{M}_{2} \underline{\mathrm{C}}$ regular complexo. MEV - elétrons secundários. 58

Figura 40 - Microestrutura da liga V6,5, mostrando a distribuição dos carbonetos $\underline{\text { eutéticos } \mathrm{MC} \text { e } \mathrm{M}_{2}} \underline{\mathrm{C}}$ : A- MC regular-complexo, B- MC irregular e $\mathbf{C}-\mathrm{M}_{2} \underline{\mathrm{C}}$ regular complexo. Ataque: Eletrolítico + Grosbeck. 
Figura 41 - Microestrutura da liga V6,5, mostrando detalhes dos carbonetos eutéticos $\underline{\mathrm{MC} \text { e } \mathrm{M}_{2}} \underline{\mathrm{C}}$ : A- MC regular-complexo, B- MC irregular e $\mathbf{C}-\mathrm{M}_{2} \underline{\mathrm{C} \text { regular complexo. }}$ MEV - elétrons secundários.

Figura 42 - Microestrutura da liga V8, mostrando a distribuição dos carbonetos

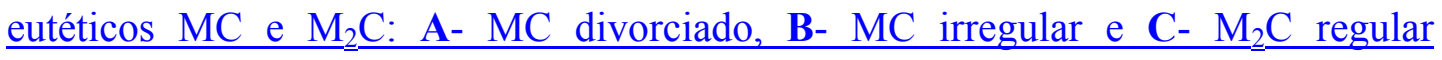
complexo. Ataque: Eletrolítico + Grosbeck.

Figura 43 - Microestrutura da liga V8, mostrando detalhes dos carbonetos eutéticos $\underline{\mathrm{MC} \text { e } \mathrm{M}_{2}} \underline{\mathrm{C}}$ : A- MC divorciado, B- MC irregular e $\mathbf{C}-\mathrm{M}_{2} \mathrm{C}$ regular complexo. MEV elétrons secundários.

Figura 44 - Matriz da liga V5, mostrando a martensita revenida e os carbonetos secundários. MEV - elétrons secundários. 62

Figura 45 - Detalhe da figura 44. MEV - elétrons secundários. 62

Figura 46 - Evolução da distribuição dos carbonetos eutéticos das ligas da primeira série de experimentos. 63

Figura 47 - Diâmetro equivalente e fator de forma do carboneto eutético MC em função da sua fração volumétrica. 65

Figura 48 - Distância livre média e continuidade entre carbonetos eutéticos em função da fração volumétrica de carboneto MC. 66

Figura 49 - Corpo-de-prova V5/650/500. A - Trinca radial e B - Trinca circunferencial. 68

Figura 50 - Caracterização macroscópica das trincas dos corpos-de-prova da primeira série de experimentos. 69 
Figura 51 - Seção transversal do corpo-de-prova V8/450 ensaiado a (a) 100 ciclos e (b) 500 ciclos, mostrando a diferença na espessura da camada de oxidação formada durante o ensaio de fadiga térmica. 70

Figura 52 - Densidade de trincas em função da fração volumétrica de carboneto eutético MC para o ensaio de 100 ciclos. .72

Figura 53 - Seção transversal do corpo-de-prova AM/450/100, mostrando trincas nucleadas na matriz. MEV - elétrons secundários. 73

Figura 54 - Seção transversal do corpo-de-prova AM/650/100, mostrando o detalhe de uma trinca de fadiga térmica nucleada na matriz e com as superfícies totalmente oxidadas. MEV - elétrons retro-espalhados. 73

Figura 55 - Seção transversal do corpo-de-prova V5/450/100, mostrando a nucleação da trinca de fadiga térmica em: A - Carboneto eutético, B - Interface carboneto/matriz e $\mathbf{C}$ - Matriz. Sem ataque. 74

Figura 56 - Seção transversal do corpo-de-prova V5/450/100, mostrando um carboneto eutético MC com trincas ramificadas localizado na superfície do corpo-deprova. MEV - elétrons retro-espalhados.

Figura 57 - Seção transversal do corpo-de-prova V8/450/100, mostrando trincas em carbonetos eutéticos MC localizados na superfície (seta A) e em carbonetos eutéticos $\underline{\mathrm{MC} \text { subsuperficiais (seta B). MEV - elétrons retro-espalhados. }}$ 75

Figura 58 - Seção transversal do corpo-de-prova V5/450/100, mostrando uma trinca

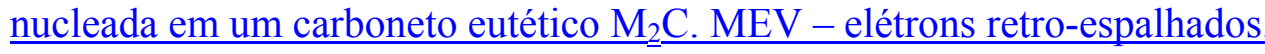
75

Figura 59 - Profundidade máxima de trinca em função da fração volumétrica de carboneto eutético MC: (a) 100 ciclos e (b) 500 ciclos. 77 
Figura 60 - Seção transversal do corpo-de-prova V6,5/450/500, mostrando o caminha de propagação de trinca: A - pela interface carboneto $\mathrm{M} 2 \mathrm{C} /$ matriz e $\mathbf{B}$ pela interface carboneto MC/matriz. Ataque: Eletrolítico + Grosbeck. 78

Figura 61 - Seção transversal do corpo-de-prova V8/550/500, mostrando o caminho de propagação de trinca: $\mathbf{A}$ - pela interface carboneto/matriz e $\mathbf{B}$ - através do próprio carboneto. Ataque: Eletrolítico + Grosbeck. 79

Figura 62 - Taxa de propagação da maior trinca em função da fração volumétrica de carboneto eutético MC: (a) 100 ciclos e (b) 500 ciclos. 81

Figura 63 - Microestrutura da liga M3,5, mostrando a distribuição dos carbonetos $\underline{\text { eutéticos } \mathrm{MC} \text { e } \mathrm{M}_{2}} \underline{\mathrm{C}}$. A- $\mathrm{MC}$ divorciado, B- $\mathrm{MC}$ irregular e C- $\mathrm{M}_{2} \underline{\mathrm{C}}$ regular complexo. Ataque: Eletrolítico +Grosbeck. 84

Figura 64 - Microestrutura da liga M3,5, mostrando detalhes dos carbonetos $\underline{\text { eutéticos } \mathrm{MC} \text { e } \mathrm{M}_{2}} \underline{\mathrm{C}}$. A- MC divorciado, B- MC irregular e C- $\mathrm{M}_{2} \underline{\mathrm{C}}$ regular complexo. MEV - elétrons secundários. 85

Figura 65 - Microestrutura da liga M5, mostrando a distribuição dos carbonetos eutéticos $\mathrm{MC}$ e $\mathrm{M} 2 \mathrm{C}$ e do carboneto $\mathrm{MC}$ primário. A- $\mathrm{MC}$ divorciado, B- $\mathrm{MC}$ irregular, C- $\mathrm{M}_{2} \mathrm{C}$ irregular e D- carboneto $\mathrm{MC}$ primário. Ataque: Eletrolítico+Grosbeck. .86

Figura 66 - Microestrutura da liga M5, mostrando detalhes dos carbonetos eutéticos

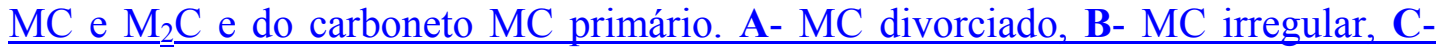

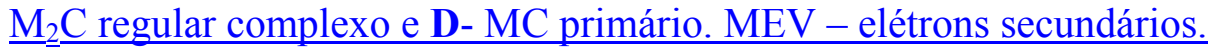
86

Figura 67 - Evolução da microestrutura das ligas da segunda série de experimentos.

Figura 68 - Diâmetro equivalente e fator de forma do carboneto eutético $\mathrm{MC}$ em função da sua fração volumétrica. 
Figura 69 - Distância livre média e continuidade do carboneto eutético em função de fração volumétrica de carboneto eutético MC. 90

Figura 70 - Caracterização macroscópica das trincas dos corpos-de-prova da segunda série de experimentos. 92

Figura 71 - Densidade de trincas em função da fração volumétrica de carboneto eutético M2C para o ensaio de 100 ciclos.

Figura 72 - Seção transversal do corpo-de-prova M5/450/500, mostrando os sítios de nucleação de trinca de fadiga térmica. A - Carboneto eutético, B - Interface carboneto/matriz e $\mathbf{C}$ - Matriz. Sem ataque. 95

Figura 73 - Seção transversal do corpo-de-prova M3,5/450/100, mostrando trincas em carboneto eutético MC localizado na superfície (A), trinca em carboneto eutético

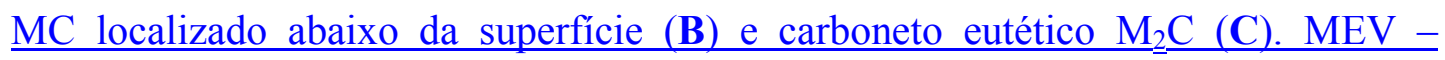
elétrons retro-espalhados. 95

Figura 74 - Seção transversal do corpo-de-prova M5/450/100, mostrando trincas em carboneto eutético MC localizado na superfície (A) e trinca em carboneto eutético MC localizado abaixo da superfície (B). MEV - elétrons retro-espalhados...... .96

Figura 75 - Seção transversal do corpo-de-prova M3,5/450/100, mostrando uma trinca nucleada na matriz e sua propagação até o carboneto eutético MC. MEV elétrons retro-espalhados. 96

Figura 76 - Profundidade máxima de trinca em função da fração volumétrica de carboneto eutético $\mathrm{M}_{2} \underline{C}$. .98

Figura 77 - Seção transversal do corpo-de-prova M5/450/500, mostrando a propagação da trinca: A - pela interface carboneto/matriz e B - pelo próprio carboneto. Sem ataque. 
Figura 78 - Taxa de propagação da maior trinca em função da fração volumétrica de carboneto eutético $\mathrm{M}_{2} \underline{\text { C. }}$.

Figura 79 - Caracterização macroscópica das trincas dos corpos-de-prova da terceira série de experimentos. 102

Figura 80 - Densidade de trincas para as ligas V5 e V8 e para os dois tamanhos de corpo-de-prova no ensaio de 100 ciclos. 104

Figura 81 - Profundidade máxima de trinca para as ligas V5 e V8 e para os dois tamanhos de corpo-de-prova nos ensaios de 100 e 500 ciclos. 105

Figura 82 - Seção transversal do corpo-de-prova V5/450/500, mostrando a propagação da trinca pela região interdendrítica. Ataque: Eletrolítico+Grosbeck. . 106

Figura 83 - Seção transversal do corpo-de-prova V5/450/100, mostrando a propagação da trinca pela interface: $\mathbf{A}$ - carboneto $\mathrm{MC} /$ matriz e $\mathbf{B}$ - carboneto M2C/matriz. Ataque: Eletrolítico+Grosbeck. 106

Figura 84 - Seção transversal do corpo-de-prova da liga V8/550/500, mostrando a propagação da trinca pelos carbonetos. Ataque: Eletrolítico+Grosbeck. 107

Figura 85 - Seção transversal do corpo-de-prova da liga V8/550/500, mostrando a propagação da trinca: $\mathbf{A}$ - pela interface carboneto $\mathrm{MC} /$ matriz, $\mathbf{B}$ - pelo carboneto MC. Ataque: Eletrolítico. 107

Figura 86 - Taxa de propagação da maior trinca para as ligas V5 e V8 e para os dois tamanhos de corpo-de-prova nos ensaios de 100 e 500 ciclos. 108

Figura 87 - Seção transversal do corpo-de-prova V5/450/100, mostrando uma trinca nucleada na matriz. MEV - elétrons secundários. 111 
Figura 88 - Distribuição de tensões na microestrutura da liga V6,5 pelo critério Von Mises. A superfície do corpo-de-prova é representada pela lateral direita da figura e a espessura apresentada é de $160 \mu \mathrm{m}$.(a) distribuição de tensões geral; (b) distribuição de tensões na matriz e (c) distribuição de tensões nos carbonetos. 112

Figura 89 - Microestrutura da liga V5, mostrando a continuidade de carbonetos MC na região interdendrítica. MEV - elétrons secundários.

Figura 90 - Representação esquemática da distribuição de carbonetos e da zona plástica na ponta da trinca (adaptada da referência 67).

Figura 91 - Representação esquemática do modo de propagação de trinca.. 116

Figura 92 - Seção transversal do corpo-de-prova M5/450/100, mostrando um carboneto trincado ao lado de uma trinca principal. MEV - elétrons retro-espalhados. 116

Figura 93 - Representação esquemática do tamanho da zona plástica na ponta da trinca. (a) região próxima à superfície do corpo-de-prova (ensaio de 100 ciclos); b) região distante da superfície do corpo-de-prova (ensaio de 500 ciclos). 117

Figura 94 - Correlação entre profundidade máxima de trinca e densidade de trincas para os corpos-de-prova ensaiados a 100 ciclos. 118

Figura 95 - Densidade de trincas em função da fração volumétrica de carboneto eutético MC para o ensaio de 100 ciclos. 119

Figura 96 - Taxa de propagação da maior trinca em função da fração volumétrica de carboneto eutético MC. 120

Figura 97 - Correlação entre densidade e profundidade de trinca para as ligas da primeira e segunda série com dureza da matriz de $450 \mathrm{HV}$ ensaiadas a 100 ciclos. 121 


\section{LISTA DE TABELAS}

Tabela 1- Evolução dos materiais da "casca" de cilindros de trabalho para as primeiras cadeiras do trem de laminação a quente de tiras 4

Tabela 2 - Carbonetos eutéticos típicos presentes na microestrutura dos ferros fundidos brancos multicomponentes para cilindros de laminação a quente e seus respectivos valores de dureza.

Tabela 3-Composição química das ligas da $1^{\mathrm{a}}$ série de experiências 40

Tabela 4 - Composição química das ligas da $2^{\mathrm{a}}$ série de experiências 40

Tabela 5 - Ciclos de revenimento aplicados e respectivos valores de dureza objetivados para cada liga.

Tabela 6 - Reagentes e técnicas de ataque para observação e medição de fração volumétrica de carbonetos eutéticos em microscópio óptico.

Tabela 7 - Fração volumétrica de carbonetos eutéticos das ligas da primeira série de experiências.

Tabela 8 - Fator de forma, diâmetro equivalente e distância livre média do carboneto eutético MC das ligas da primeira série de experimentos. 65

Tabela 9-Valores médios de microdureza da matriz dos corpos-de-prova da primeira série de experiências 67

Tabela 10 - Densidade de trincas dos corpos-de-prova da primeira série de experimentos ensaiados a 100 ciclos 71 
Tabela 11 - Profundidade máxima de trinca dos corpos-de-prova da primeira série de experimentos

Tabela 12 - Taxa de propagação da maior trinca dos corpos-de-prova da primeira $\underline{\text { série de experimentos }}$

Tabela 13 - Valores médios de microdureza da matriz das ligas da primeira série de experimentos após os ensaios de 100 e 500 ciclos.

Tabela 14 - Valores médios de fração volumétrica de carbonetos eutéticos das ligas da segunda série de experiências 88

Tabela 15 - Fator de forma, diâmetro equivalente e distância livre média do $\underline{\text { carboneto eutético MC das ligas da segunda série de experimentos }}$ 89

Tabela 16 - Valores médios de microdureza da matriz dos corpos-de-prova da segunda série de experimentos. 90

Tabela 17 - Densidade de trincas dos corpos-de-prova da segunda série de experimentos ensaiados a 100 ciclos 93

Tabela 18 - Profundidade máxima de trinca dos corpos-de-prova da segunda série de experimentos

Tabela 19 - Taxa de propagação da maior trinca dos corpos-de-prova da segunda $\underline{\text { série de experimentos }}$

Tabela 20 - Densidade de trincas dos corpos-de-prova da terceira série de experimentos ensaiados a 100 ciclos 103

Tabela 21 - Profundidade máxima de trinca dos corpos-de-prova da terceira série de experimentos 105 
Tabela 22 - Taxa de propagação da maior trinca dos corpos-de-prova da terceira

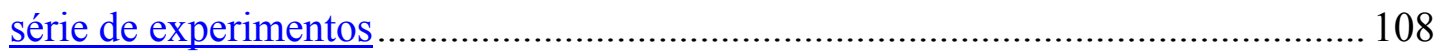

Tabela 23 - Parâmetro C/Dm do carboneto eutético para as ligas da primeira série de

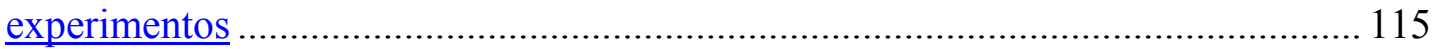

Tabela 24 - Parâmetro C/Dm do carboneto eutético para as ligas da segunda série de

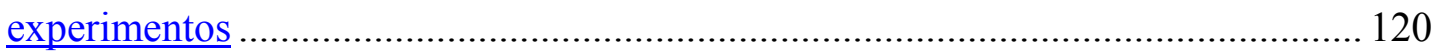




\section{LISTA DE ABREVIATURAS E SIGLAS}

IPT - Instituto de Pesquisas Tecnológicas do Estado de São Paulo

USP - Universidade de São Paulo

P\&D - Pesquisa e Desenvolvimento

PADCT - Programa de Apoio ao Desenvolvimento Científico e Tecnológico

FAPESP - Fundação de Amparo à Pesquisa do Estado de São Paulo

EPUSP - Escola Politécnica da USP

ASTM - American Standard for Testing Materials 


\title{
LISTA DE SÍMBOLOS
}

\author{
$\alpha \quad$ coeficiente de expansão térmica \\ $\sigma \quad$ tensão trativa \\ E módulo de elasticidade \\ $v \quad$ coeficiente de Poisson \\ $h \quad$ coeficiente de transferência de calor \\ $k \quad$ condutividade térmica \\ $\varepsilon_{\mathrm{p}} \quad$ deformação plástica \\ $\varepsilon_{\mathrm{f}} \quad$ coeficiente de dutilidade em fadiga \\ $\varepsilon_{\mathrm{t}}$ deformação térmica \\ $\varepsilon_{\mathrm{e}} \quad$ deformação elástica \\ of limite de ruptura \\ $\gamma \quad$ energia de superfície de fratura
}




\section{RESUMO}

Estudaram-se os efeitos da fração volumétrica de carboneto eutético e da dureza da matriz sobre a resistência à fadiga térmica de ferros fundidos brancos multicomponentes. Utilizaram-se ligas do sistema Fe-4Cr-V-2Mo-2W-2C, V variando entre 5 e $8 \%$ e Fe-4Cr-8V-Mo-2W-2C, Mo variando entre 2 e 5\%. Corposde-prova com a geometria de discos com seção variável foram temperados e revenidos para obtenção de dois valores de microdureza da matriz: $450 \mathrm{HV}$ e 650 $\mathrm{HV}$. Conduziram-se ensaios de fadiga térmica por 100 e 500 ciclos. Cada ciclo envolveu aquecimento por indução da superfície até a temperatura de $600^{\circ} \mathrm{C} \mathrm{em} 10$ segundos e subseqüente resfriamento em água por 45 segundos (equalização das temperaturas do núcleo e da superfície).

Os corpos-de-prova foram caracterizados antes e após os ensaios de fadiga térmica. Antes dos ensaios, caracterizaram-se os carbonetos eutéticos (tipos, morfologia, fração volumétrica, tamanho, forma e distribuição dos carbonetos) e a microdureza da matriz. Após os ensaios, caracterizaram-se as trincas de fadiga térmica macroscópicas e microscópicas (número e profundidade) e a microdureza da matriz.

A nucleação de trincas de fadiga térmica ocorre predominantemente na superfície do corpo-de-prova, induzidas por concentradores de tensão mecânicos e metalúrgicos. As trincas nucleiam na matriz (a rugosidade age como concentrador de tensão mecânico) e em carbonetos (interface carboneto/matriz ou no próprio carboneto). A taxa de nucleação sofre influência da fração volumétrica de carboneto eutético (seu aumento promove aumento da taxa de nucleação) e da dureza da matriz (seu aumento promove diminuição da taxa de nucleação).

A propagação de trincas ocorre predominantemente pela interface carboneto/matriz ou através do carboneto. A taxa de propagação sofre influência da distribuição de carboneto eutético. Quanto maior a relação "continuidade de carbonetos/distância livre média entre carbonetos", maior a taxa de propagação de trincas.

A taxa de propagação de trinca diminui com o aumento do tempo de ensaio, independentemente da fração volumétrica de carboneto eutético e da dureza da matriz. O regime de propagação durante os primeiros 100 ciclos é caracterizado pela propagação instável da trinca controlada pela tenacidade à fratura do material; de 100 a 500 ciclos, a propagação é controlada pela magnitude da tensão.

O tamanho do corpo-de-prova também influenciou os resultados dos ensaios: o aumento do tamanho promove aumento das taxas de nucleação e propagação. Este resultado é atribuído ao aumento do gradiente térmico ao longo do corpo-de-prova com o aumento do seu diâmetro. 


\begin{abstract}
The effects of the volume fraction of eutectic carbides and of the matrix hardness on the thermal fatigue resistance of multicomponent white cast iron were investigated. Alloys Fe-4Cr-V-2Mo-2W-2C, V ranging from 5 to $8 \mathrm{wt} \%$ and Fe-4Cr-8V-Mo-2W$2 \mathrm{C}$, Mo ranging from 2 to $5 \mathrm{wt} \%$ were used. Disc shaped samples were quench and tempered for obtaining two matrix microhardness levels: $450 \mathrm{HV}$ and $650 \mathrm{HV}$.

Thermal fatigue tests were carried out for 100 and 500 cycles. Each cycle involved high frequency induction heating of the surface to $600^{\circ} \mathrm{C}$ and subsequent cooling in water during 45 seconds (equalization of the bulk and surface temperature).

The test specimens were characterized before and after the thermal fatigue tests. Before the tests, eutectic carbide (type, morphology, volume fraction, syze, shape and distribution of carbides) and matrix microhardness were characterized. After the tests, the macroscopic and microscopic thermal fatigue cracks (number and depth) and matrix microhardness were characterized.

The nucleation of the thermal fatigue cracks takes place mostly at the specimen surface, induced by mechanical and metallurgical stress risers. The crack nucleates at the matrix (roughness as mechanical stress risers as well as at carbides (at the carbide/matrix interface or at the carbide itself). The nucleation rate is influenced by the volume fraction of eutectic carbide (the higher the volume fraction, the higher the nucleation rate) and by the matrix microhardness (the higher the microhardness, the lower the nucleation rate).

The crack propagation mostly takes place at the carbide/matrix interface or through the carbide. The propagation rate is affected by the carbide distribution. The higher the "carbide continuity/carbide free path" ratio, the higher the propagation rate.

The propagation rate decreases with increasing test time, regardless the eutectic carbide volume fraction and the matrix microhardness. The propagation behaviour during the first 100 cycles is characterized by instable crack propagation controlled by the fracture toughness of the material; from 100 to 500 cycles, the propagation is controlled by the stress magnitude.

The syze of the test specimen also influenced the tests results: the larger the specimen syze, the higher the nucleation and propagation rates. This is attributed to the effect of increasing thermal gradient across the specimen with increasing specimen diameter.
\end{abstract}




\section{INTRODUÇÃO}

\subsection{Considerações gerais}

\subsubsection{Histórico}

Ao longo dos últimos 15 anos, atividades sistemáticas na área de Materiais Metálicos Fundidos Resistentes a Desgaste têm sido desenvolvidas pelo Laboratório de Fundição da Divisão de Metalurgia do IPT, invariavelmente em conjunto com a Escola Politécnica da USP (Departamento de Engenharia Mecânica e Departamento de Engenharia Metalúrgica e de Materiais) e o meio industrial. Relacionam-se, no âmbito destas atividades, projetos de pesquisa e desenvolvimento, teses e dissertações, publicação de artigos, seminários nacionais e cursos de pós-graduação.

Até meados da década de 1990, as atenções concentraram-se sobre as famílias dos ferros fundidos brancos de alto cromo aplicada à fundição de corpos moedores; a produção técnica deste período materializou-se em dois projetos de $\mathrm{P} \& \mathrm{D}$ financiados pelo programa PADCT, uma tese de doutoramento e um projeto de transferência de tecnologia para uma empresa de fundição.

A partir de então, o foco das atividades deslocou-se para a família dos ferros fundidos brancos multicomponentes, com ênfase na solidificação e formação da microestrutura bruta de fundição, daí decorrendo a realização de uma tese de doutoramento e dois projetos de P\&D financiados pela Fapesp.

Mais recentemente, estabeleceu-se uma estreita cooperação com o Laboratório de Fenômenos de Superfície da EPUSP e a Unidade de Cilindros da Aços Villares/Sidenor voltada ao desenvolvimento de produtos e processos ligados a cilindros de laminação, envolvendo, dentre outros, a aplicação de uma vertente dos ferros fundidos brancos multicomponentes.

O presente trabalho faz parte desta cooperação e aborda o comportamento destes ferros fundidos brancos multicomponentes sob fadiga térmica, que está entre as principais causas de degradação de cilindros de laminação a quente. 


\subsubsection{Cilindros de laminação a quente - materiais e degradação}

A tecnologia da laminação a quente de tiras de aço tem avançado no sentido de melhorar a qualidade do produto laminado e aumentar a produtividade do trem de laminação, uma vez que: i) a tendência dos maiores consumidores de produtos siderúrgicos planos- indústrias automobilística e de eletrodomésticos- é a de exigir níveis crescentes de qualidade dimensional e superficial das tiras de aço laminadas a quente; ii) neste setor, o mercado é caracterizado por acirrada competição, grandes volumes e margens de lucro reduzidas, tornando vitais aspectos relativos à produtividade da indústria siderúrgica.

Na produção de tiras a quente, qualidade e produtividade estão intimamente ligadas ao desempenho em serviço dos cilindros de laminação. A qualidade do produto laminado é determinada principalmente por sua forma, rugosidade e variação dimensional, que estão diretamente associadas à forma e à rugosidade dos cilindros de trabalho do trem acabador (este, via de regra, é constituído de seis ou sete cadeiras de laminadores quádruos). A produtividade do trem acabador, por sua vez, é parcialmente determinada pelo tempo de serviço ininterrupto que o cilindro de trabalho pode suportar, mantendo a qualidade do produto laminado acima do nível mínimo estabelecido (os cilindros de trabalho são periodicamente retirados de serviço para recuperação da sua superfície, que nada mais é do que a remoção, por usinagem, da camada superficial deteriorada pelo próprio uso) ${ }^{1}$. A figura 1 mostra, esquematicamente, uma linha de produção de tiras laminadas a quente.

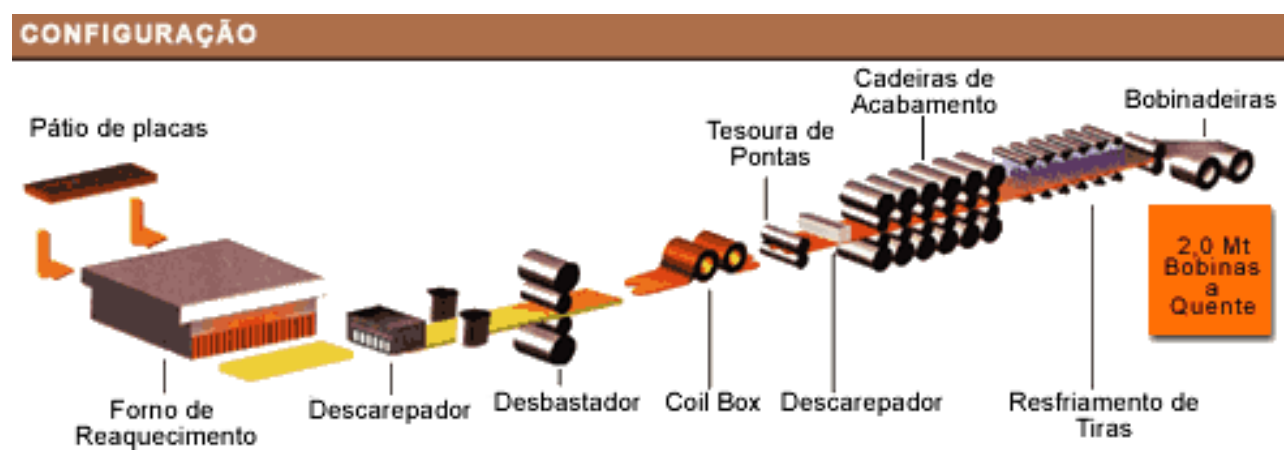

Figura 1 - Esquema de uma linha de produção de tiras laminadas a quente.

Os cilindros de trabalho destinados a trens de laminação de tiras a quente são, na maioria dos casos, componentes bimetálicos constituídos de uma "casca” externa 
de liga resistente a desgaste fundida por centrifugação (com espessura da ordem de $60 \mathrm{~mm}$ ) e um "núcleo" de ferro fundido nodular ou de aço (fundido ou forjado) ${ }^{1}$.

Nas últimas cadeiras empregam-se cilindros com "casca" de ferro fundido mesclado com grafita sob a forma de veios curtos ou nódulos, similares aos ferros fundidos do tipo "Ni-Hard" (ASTM A-532). É interessante notar que este material vem sendo utilizado há mais de 40 anos, provavelmente devido às suas boas características de resistência ao colamento da chapa contra o cilindro. Nas três primeiras cadeiras, ao contrário, o desenvolvimento de ligas para a "casca" dos cilindros tem sido intenso nos últimos 20 anos, culminando com a aplicação de ligas do sistema Fe-C-Cr-W-Mo-V, denominadas ferros fundidos brancos multicomponentes ${ }^{1}$. A tabela 1 mostra as faixas de composição química típicas destas ligas e das suas antecessoras, bem como uma descrição sumária das suas microestruturas e o período durante o qual cada uma delas figurou (ou figura) como "produto preferencial” nas indústrias siderúrgicas. 
Tabela 1- Evolução dos materiais da "casca" de cilindros de trabalho para as primeiras cadeiras do trem de laminação a quente de tiras

\begin{tabular}{|c|c|c|c|}
\hline Material & $\begin{array}{c}\text { Composição } \\
(\% \text { em } \\
\text { peso })\end{array}$ & Microestrutura & Período \\
\hline Ferro fundido mesclado & $\begin{array}{c}\mathrm{C}: 3,0-3,4 \\
\mathrm{Ni}: 4-5 \\
\mathrm{Cr}<2 \\
\mathrm{Mo}<1\end{array}$ & $\begin{array}{c}\text { Matriz com martensita e } \\
\text { austenita retida } \\
\text { Carboneto eutético } \mathrm{M}_{3} \mathrm{C} \\
\text { Grafita em grumo }\end{array}$ & $\begin{array}{l}1950- \\
1980\end{array}$ \\
\hline Adamite & $\begin{array}{c}\mathrm{C}: 0,7- \\
\mathrm{AM} \\
\mathrm{Ni}: 1,2-1,5 \\
\mathrm{Cr}<2 \\
\mathrm{Mo}<1\end{array}$ & Martensita revenida & $\begin{array}{l}1950- \\
1980\end{array}$ \\
\hline $\begin{array}{l}\text { Ferro branco } \\
\text { de alto cromo }\end{array}$ & $\begin{array}{c}\text { C: } 2 \text { - } 3 \\
\text { Ni: } 1 \text { - } 2 \\
\text { Cr: } 10-18 \\
\text { Mo: } 1 \text { - } 3\end{array}$ & $\begin{array}{c}\text { Matriz de martensita } \\
\text { revenida } \\
\text { Carboneto eutético } \mathrm{M}_{7} \mathrm{C}_{3}\end{array}$ & $1980-$ \\
\hline $\begin{array}{l}\text { Ferro fundido branco } \\
\text { multicomponente }\end{array}$ & $\begin{array}{c}\text { C: } 1,5-2,5 \\
\text { Cr: } 4-7 \\
\text { Mo: }<5 \\
\text { V: } 4-8 \\
\text { W: }<5\end{array}$ & $\begin{array}{c}\text { Matriz de martensita } \\
\text { revenida } \\
\text { Carbonetos eutéticos } \mathrm{MC} \text {, } \\
\mathrm{M}_{2} \mathrm{C} \text { e } \mathrm{M}_{7} \mathrm{C}_{3}\end{array}$ & 1990- \\
\hline
\end{tabular}

A deterioração dos cilindros de trabalho de trens de laminação de tiras a quente é um processo complexo caracterizado pela ação simultânea de vários modos de desgaste, tais como abrasão, oxidação, adesão e fadiga térmica ${ }^{2,3}$. Estão envolvidas interações microscópicas e dinâmicas na interface entre o cilindro e o material laminado, sendo praticamente impossível observá-las diretamente. Sabe-se, porém, que há certa prevalência de um ou dois daqueles modos de desgaste em cada cadeira ou conjunto de cadeiras do trem de laminação, dependendo principalmente 
da temperatura de laminação. Desta forma, nas três primeiras cadeiras (temperatura mais elevada) os fenômenos de fadiga térmica e oxidação apresentam-se de forma mais intensa, enquanto nas duas últimas, abrasão e adesão são os fenômenos predominantes. Nas cadeiras intermediárias, por conseguinte, observa-se a ação de todos eles de maneira aproximadamente eqüitativa.

Durante a laminação a quente de tiras, o aquecimento dos cilindros de trabalho, que é decorrente do contato com a tira laminada, da deformação plástica aplicada à tira e do atrito entre o cilindro e a tira, produz três fatores importantes: dilatação dos cilindros, alterando a forma do seu perfil e, conseqüentemente, a dinâmica do processo de laminação; gradiente térmico acentuado ao longo do raio dos cilindros; deterioração das características mecânicas do material da "casca" dos cilindros, tornando possível a adesão da tira a eles. Para reduzir estes efeitos, os cilindros de trabalho são refrigerados por meio de jatos d'água durante o período em que suas superfícies estão fora do arco de contato com a tira laminada ${ }^{4}$.

Desta forma, a superfície dos cilindros de trabalho é submetida a ciclos térmicos que se repetem a cada rotação do cilindro, enquanto a região interna dos cilindros permanece a uma temperatura constante. A literatura mostra que, nas primeiras cadeiras de trens de laminação a quente de tiras de aço, a superfície dos cilindros de trabalho pode atingir temperaturas entre $600^{\circ} \mathrm{C}$ e $650^{\circ} \mathrm{C}$, enquanto o núcleo, em condições de regime permanente, mantém-se a temperaturas da ordem de $80^{\circ} \mathrm{C}^{4,5}$. Adicionalmente, verificou-se, por modelagem matemática, que a região superficial submetida a ciclos térmicos possui espessura de, no máximo, 1\% do raio do cilindro, conforme mostra a figura $2^{6}$. Na figura, o autor do trabalho utilizou uma temperatura normalizada, mas ele não especifica qual o parâmetro utilizado para essa normalização. 


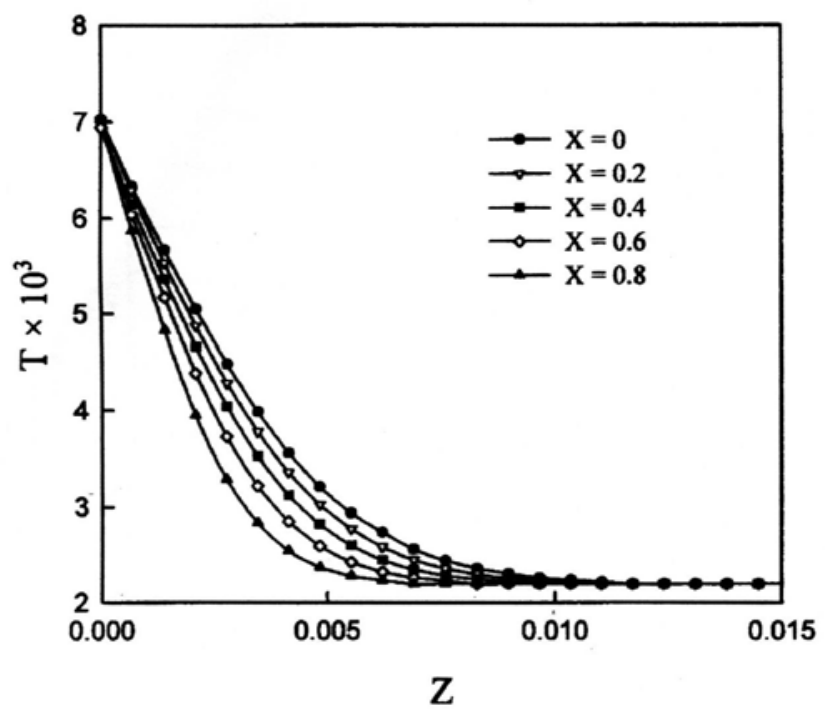

Figura 2 - Variação da temperatura ao longo do raio do cilindro de trabalho na região do arco de contato durante laminação a quente $(Z=$ fração do raio do cilindro; $\mathrm{X}=$ fração do comprimento do arco de contato) ${ }^{6}$.

As alterações de temperatura a que fica submetida a superfície dos cilindros de trabalho durante cada ciclo de rotação produzem solicitação cíclica sobre ela, de acordo com o modelo sumariamente descrito a seguir ${ }^{4}$. No aquecimento, a superfície é rapidamente aquecida e tende a dilatar, o que não ocorre com todo o restante do cilindro; assim, aquela dilatação fica restringida e, conseqüentemente, a superfície fica submetida à tensão de compressão, que pode ser superior ao limite de escoamento do material do cilindro de trabalho e causar deformação plástica microscópica na região da superfície. No resfriamento, após sair do arco de contato, a superfície tende a contrair (recuperando deformação elástica que não é suprimida pela deformação plástica anterior), mas novamente é restringida pelo restante do cilindro (cujas dimensões, sob regime permanente, não se alteram em momento algum) e fica submetida a tensão de tração. O ciclo compressão-tração descrito conduz à nucleação de trincas na superfície dos cilindros de trabalho, denominadas trincas térmicas, cujo crescimento subseqüente, facilitado pela ação dos próprios esforços de laminação, dá origem ao arranjo mostrado na figura 3, denominado malha de trincas térmicas. 


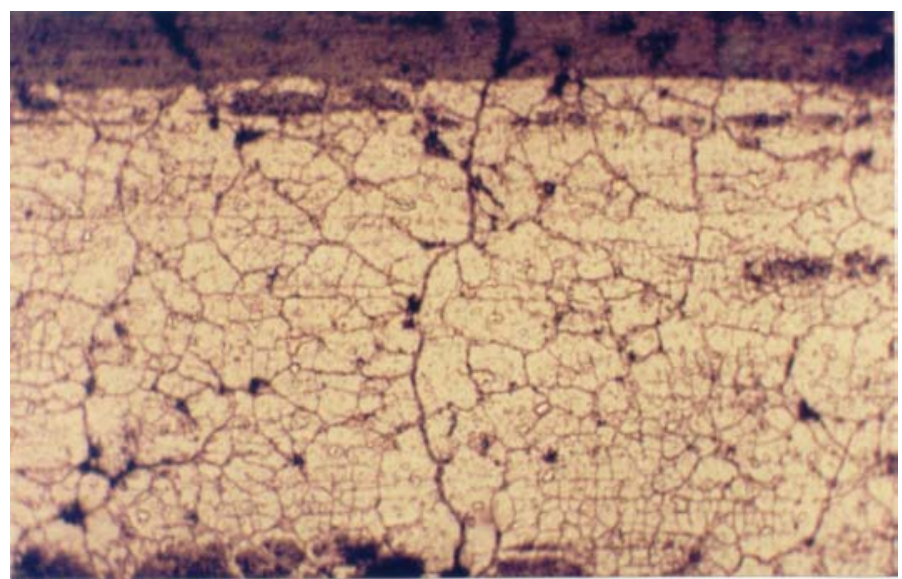

Figura 3- Malha de trincas térmica na superfície de cilindro de trabalho de ferro fundido branco multicomponente. Sem ataque. (100X).

O fenômeno de fadiga térmica não é observado isoladamente nos cilindros de trabalho, estando invariavelmente combinado a outros tipos de solicitação sobre a superfície dos mesmos, principalmente à oxidação causada pela associação das condições de altas temperaturas e meio agressivo que prevalecem na laminação a quente. Essa oxidação forma uma camada contínua na superfície do cilindro, agindo como um lubrificante sólido e protegendo a superfície do desgaste abrasivo ${ }^{7}$. Entretanto, a camada de óxido não protege a superfície da ação da fadiga térmica e esta combinação dá origem ao principal modo de degradação progressiva dos cilindros de trabalho das três primeiras cadeiras de trens de laminação de tiras a quente, denominado "banding”. Em resumo, trata-se do destacamento localizado do óxido formado na superfície do cilindro juntamente com fragmentos metálicos da região subsuperficial, dando origem a irregularidades macroscópicas na superfície que são reproduzidas nas tiras laminadas e que provocam sucateamento destas.

A figura 4 mostra um cilindro com ocorrência de "banding", nas regiões marcadas pela letra $\mathrm{B}$ (as regiões marcadas pela letra $\mathrm{N}$ apresentavam condições normais). 


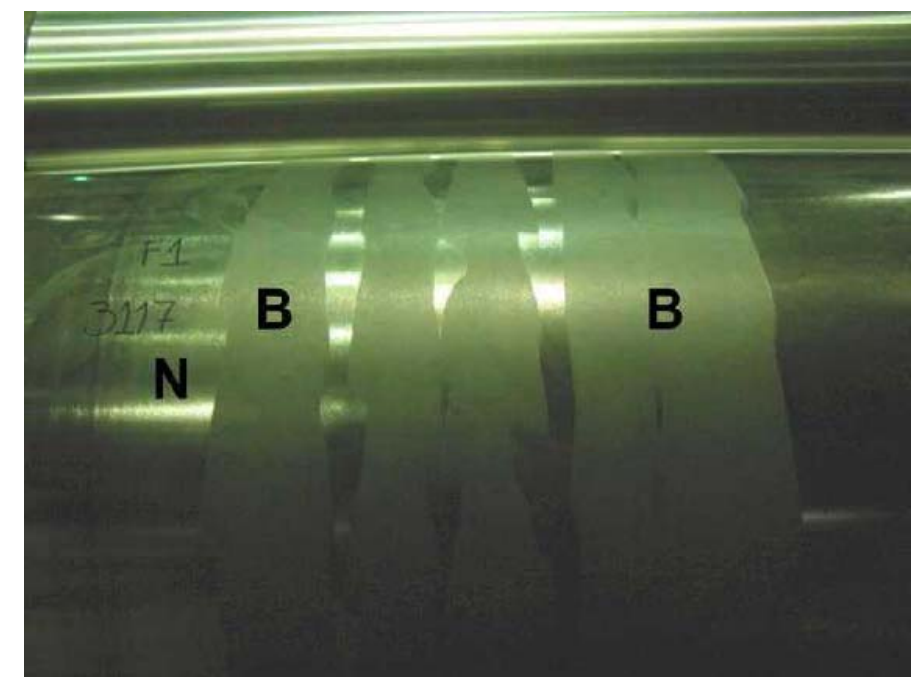

Figura 4 - Cilindro de laminação a quente com ocorrência de "banding".

A figura 5 mostra um desenho esquemático do modelo proposto por deBarbadillo ${ }^{8}$ para a formação do "banding", sendo possível associar as respectivas regiões $\mathrm{B}$ e $\mathrm{N}$ com as apresentadas na figura anterior.
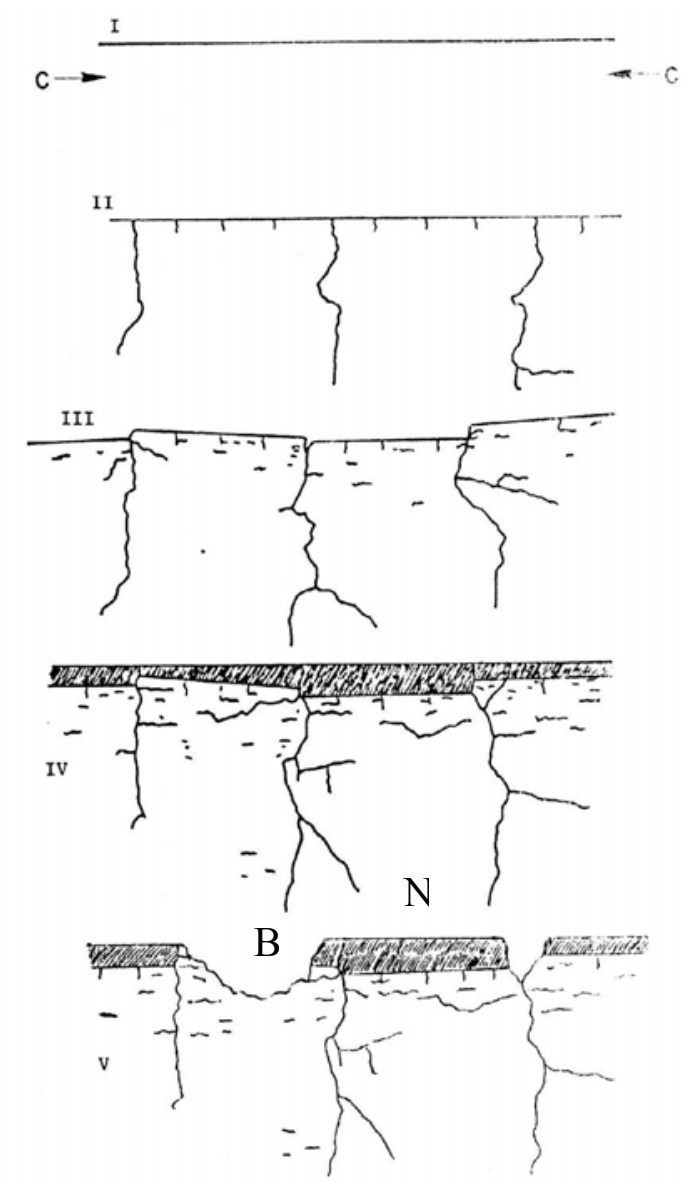

Figura 5- Representação esquemática do modelo de formação do "banding"8. 


\subsection{Fadiga térmica}

\subsubsection{Tensões térmicas}

Em geral, as tensões térmicas são abordadas pela literatura partindo da deformação de um componente gerada pelo seu resfriamento ou aquecimento (contração ou dilatação do componente) para, a partir daí, apresentar as equações que regem as tensões desenvolvidas sob solicitações uniaxial e biaxial ${ }^{9,10,11,12}$. A mesma abordagem será utilizada nessa revisão.

Se uma barra de comprimento L é resfriada de uma temperatura (T2) para outra (T1), ela irá contrair segundo a equação

$$
\Delta L=\alpha(T 2-T 1) L
$$

onde $\alpha$ é o coeficiente de expansão térmica do material da barra. Entretanto, se as extremidades dessa barra estiverem fixas, de tal forma a restringir a contração, ela ficará submetida a uma tensão de tração dada por (Lei de Hooke)

$$
\sigma=E \alpha(T 2-T 1)
$$

onde E é o módulo de elasticidade do material da barra.

No caso de uma chapa com largura e comprimento similares e muito maiores do que a espessura, em que a restrição à contração é aplicada no próprio plano da chapa, desenvolve-se um estado plano de tensões com

$$
\sigma=\frac{E \alpha \Delta T}{1-v}
$$

onde $v$ é o coeficiente de Poisson.

É importante ressaltar que essas equações foram baseadas na hipótese de que todo o componente passa de uma temperatura para outra instantaneamente, ou seja, não há gradiente térmico ao longo do corpo nas temperaturas consideradas. Podemos considerar, portanto, que esta situação é similar à de um corpo em que uma fina camada superficial é submetida a variações cíclicas de temperatura entre T1 e T2, em que a limitação à deformação (contração e dilatação) é imposta pelo interior do próprio componente que se mantém a uma temperatura constante.

No caso mais geral, em que a cinética de transporte de calor no próprio corpo e entre o corpo e o meio em que ele está imerso não é infinita, a magnitude das tensões térmicas passa a depender também do coeficiente de transferência de calor 
(h) entre o corpo e o meio em que está imerso, do coeficiente de condutividade térmica do material do corpo $(k)$ e da geometria do corpo, parâmetros que podem ser incorporados num parâmetro adimensional, o número de Biot $(B i)$

$$
B i=\frac{x h}{k}
$$

em que $x$ é a relação entre volume e superfície de resfriamento do corpo.

Quando as dimensões do componente são grandes, o coeficiente de transferência de calor é elevado e a condutividade térmica é baixa, os valores de $B i$ são altos e as tensões térmicas atingem as dadas pelas equações (2) e (3), que se referem a este caso particular e extremo ${ }^{9,13}$.

Para um caso mais específico, como um material compósito, as tensões variam diretamente com as diferenças entre os coeficientes de expansão térmica das suas fases ou constituintes. Considerando um material com deposição de uma fina camada em sua superfície, a equação 3 pode ser escrita da seguinte forma ${ }^{14}$

$$
\sigma=\frac{E \Delta \alpha \Delta T}{1-v}
$$

sendo $\Delta \alpha$ a diferença entre os coeficientes de expansão térmica do substrato e da camada. A fase ou constituinte que possuir o maior valor do coeficiente de expansão térmica será a fase que estará sob tração no resfriamento ${ }^{9}$. Por exemplo, em materiais que possuem aplicação de uma camada cerâmica para atuar como barreira térmica, como é o caso de palhetas de turbina a gás, a falha em serviço ocorre por meio de decoesão seguida de descolamento da camada cerâmica. Isso ocorre em função da diferença entre os coeficientes de expansão térmica da camada (menor $\alpha$ ) e do substrato (maior $\alpha$ ), que promove a tensão de tração no substrato, nucleando trincas na interface substrato/matriz ${ }^{9}$. Para outras estruturas de compósitos, as tensões geradas pela diferença de expansão térmica são mais complexas e envolvem as propriedades elásticas de cada fase presente ${ }^{14}$. A influência dessa diferença de coeficientes de expansão se torna ainda mais significativa. 
1.2.2. Trincas causadas por fadiga térmica - aspectos microscópicos

A literatura não aborda a nucleação e a propagação de trincas decorrente especificamente de solicitações cíclicas induzidas por alterações térmicas. O tema é tratado dentro do contexto geral do processo de fadiga. Este procedimento será adotado neste trabalho.

\subsubsection{Nucleação}

A nucleação de trincas, assim como todo o processo de fadiga, é controlada pela deformação plástica cíclica microscópica e localizada (em materiais que apresentam deformação plástica $)^{10,15,16,17}$. As trincas de fadiga nucleiam, portanto, em posições onde a deformação plástica cíclica é maior do que a média.

Na maioria dos casos, essas trincas nucleiam nas superfícies livres de metais expostos ao carregamento cíclico, seja por meio de tensão externa aplicada ou tensão gerada por mudanças periódicas de temperatura. Isso ocorre porque a deformação plástica cíclica é maior nas superfícies livres, devido às maiores tensões desenvolvidas e ao menor grau de restrição à deformação dessas regiões (os grãos da superfície possuem menos grãos vizinhos para limitar a deformação plástica $)^{9,18,19}$.

Entretanto, as trincas também podem ser nucleadas em defeitos internos ou segundas fases da microestrutura, dependendo da concentração de tensão que esses elementos causam ${ }^{9,19}$.

Há basicamente três tipos de sítios para a nucleação de trincas de fadiga ${ }^{15}$ :

- Bandas persistentes de deformação (geradas durante o processo de carregamento cíclico)

- Contornos de grão

- Partículas de segunda fase

Nos materiais que possuem em sua microestrutura partículas de segunda fase, essas são sítios preferenciais de nucleação de trincas.

\section{$\underline{\text { Partículas de segunda fase }}$}

A nucleação de trincas em partículas de segunda fase pode ser entendida como deformação cíclica localizada devido ao efeito de concentração de tensão das partículas de segunda fase ${ }^{15}$. A interação entre as bandas de deformação e as 
partículas de segunda fase leva a concentração de tensão localizada na interface partícula/matriz, promovendo a formação da trinca por meio da decoesão nessa interface.

A figura $6^{19}$ mostra a influência do tamanho do carboneto e/ou poro na vida útil da superliga MAR-M200, solidificada direcionalmente quando submetida a fadiga mecânica à temperatura ambiente. A vida à fadiga da superliga diminui com o aumento do tamanho dos poros e/ou dos carbonetos.

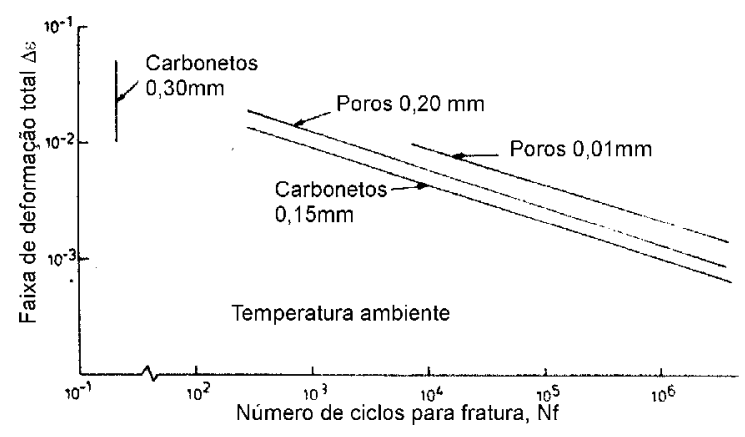

Figura 6 - Efeito do tamanho do carboneto e/ou poro sobre a vida à fadiga à temperatura ambiente da superliga MAR-M200 solidificada direcionalmente ${ }^{19}$.

Embora seja uma condição de fadiga mecânica, é possível aplicá-la para o caso de fadiga térmica, visto que é bastante provável que a concentração de tensão em segundas fases ocorra da mesma forma para os dois casos.

Para o caso de fadiga térmica, há ainda um outro fator que promove a nucleação de trincas em interfaces partículas/matriz. A diferença entre os coeficientes de expansão térmica da partícula e da matriz favorece a nucleação de trincas nas partículas e/ou na interface partícula/matriz, segundo a equação (5) e o raciocínio apresentados no item 1.2.1.

Resultados da literatura mostram a nucleação de trincas em carbonetos primários e/ou eutéticos ou na interface entre o carboneto e a matriz em superligas $^{20,21}$.

\section{Contornos de grão}

Há três mecanismos propostos para explicar nucleação de trincas de fadiga em contornos de grão ${ }^{15,19}$. 
No primeiro mecanismo os contornos de grão são responsáveis por deformação plástica microscópica heterogênea, levando à formação de vinco que evolui para microtrinca ${ }^{15}$.

No segundo mecanismo, a interação entre as bandas persistentes de escorregamento, PSBs, e os contornos de grão levam a uma concentração de tensão que pode causar uma decoesão ao longo do contorno de grão ${ }^{15}$.

O terceiro mecanismo é mais efetivo em solicitações de fluência, mas segundo Weronski ${ }^{11}$, também é importante para o caso de fadiga térmica. É o caso de nucleação em pontos triplos devido ao escorregamento dos grãos. Essas trincas nucleiam, em geral, para pequenas deformações. Sob tensão de tração, há escorregamento dos contornos de grão, aumentando as tensões nos pontos triplos e gerando a formação de uma "dobra" intergranular ou a nucleação de uma trinca. Qualquer crescimento dessa trinca também é governado pelo processo de escorregamento dos contornos de grão ${ }^{19}$.

Há resultados da literatura que mostram eventos de nucleação de trincas tanto de fadiga térmica quanto fadiga mecânica em contornos de grão ${ }^{22,23,24}$.

\subsubsection{Propagação}

O mecanismo de propagação de trincas de fadiga pode ser dividido em três estágios, como mostra a figura $7^{18}$.

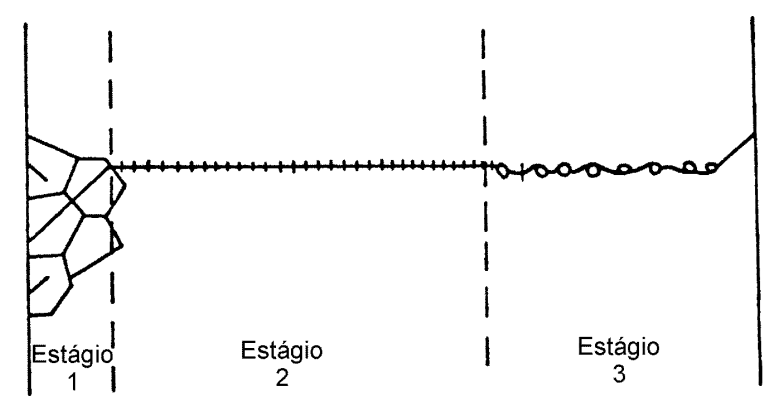

Figura 7 - Estágios de propagação de trinca de fadiga ${ }^{18}$.

As principais características do início da propagação (estágio I) são a presença de deformação plástica (este estágio é muitas vezes considerado apenas 
uma extensão da etapa de nucleação), a reduzida dimensão (da ordem de alguns grãos do material) e a direção de propagação $\left(45^{\circ}\right.$ em relação à tensão de tração principal, isto é, a direção de máxima tensão de cisalhamento) ${ }^{18}$. A superfície de fratura associada ao estágio I não exibe estrias de fadiga regularmente espaçadas.

O segundo estágio de propagação, que é responsável pela formação da maior parte da superfície de fratura ocorre numa direção perpendicular à direção de aplicação da tensão de tração principal. A fratura é mais afetada pela magnitude da tensão alternada do que pela tensão média ou microestrutura. Nesse estágio, a superfície de fratura normalmente exibe marcas regulares, conhecidas como estrias, que são uma "gravação" visual da posição da frente da trinca de fadiga a cada ciclo durante a sua propagação ${ }^{25}$. Cada estria representa o avanço da trinca como resultado de um ciclo de carregamento, em que sua extensão varia com a amplitude de tensão ${ }^{9,25}$ ou de vários ciclos ${ }^{25}$.

As estrias de fadiga são relativamente planas e assumem uma aparência de clivagem quando formadas num meio agressivo. Além de alterar a morfologia das estrias, o meio pode causar outras mudanças, como suprimir sua formação ou apagálas, se oxidante (alta temperatura) ${ }^{9}$.

O estágio III é formado no último ciclo do processo de fratura e, a rigor, não ocorre por ação de fadiga. $\mathrm{Na}$ verdade, caracteriza-se por ser um processo de fratura frágil (propagação instável quando, no estágio II, a trinca atinge o tamanho crítico) ou de fratura dúctil (propagação estável em materiais de elevada tenacidade quando, no estágio II, a seção resistente residual é sobrecarregada).

\subsubsection{Fadiga térmica em materiais dúcteis}

Não há na literatura sobre fadiga térmica uma abordagem clara sobre o tema em relação à nucleação e propagação de trincas expressas sob a forma de previsão da vida à fadiga térmica do material (número de ciclos para fratura, $\mathrm{N}_{\mathrm{f}}$, e taxa de propagação de trinca, da/dN), como acontece para a fadiga mecânica ${ }^{9,11,13,14,26,27}$. De uma forma geral, emprega-se as relações de Coffin-Manson (Nf) e de Solomon $(\mathrm{da} / \mathrm{dN})$ para o caso de fadiga de baixo ciclo (deformação plástica maior do que a deformação elástica), que é o caso de fadiga térmica ${ }^{10,28,29,30}$.

Assim tem-se: 
Equação de Coffin-Manson: $\left(N_{f}\right)^{c} \cdot \Delta \varepsilon_{p}=C \cdot \varepsilon_{f}$

em que $\mathrm{N}_{\mathrm{f}}$ é o número de ciclos para iniciar a fratura, $\Delta \varepsilon_{\mathrm{p}}$ é a amplitude de deformação plástica, $\varepsilon_{\mathrm{f}}$ é o coeficiente de ductilidade em fadiga (deformação total real sob tração monotônica), $c$ é o expoente de ductilidade à fadiga $(0<c<1$ e normalmente em torno de 0,5$)$ e $C$ é uma constante $(0<C<1)$.

$$
\text { Equação de Solomon: } \frac{d a}{d N}=p a\left(\Delta \varepsilon_{p}\right)^{q}
$$

em que a é o comprimento de trinca, $\mathrm{N}$ é o número de ciclos, $\Delta \varepsilon_{\mathrm{p}}$ é a amplitude de deformação plástica e $p$ e $q$ são constantes positivas.

Malm e Norströn desenvolveram um modelo para relacionar $\mathrm{Nf}$ e da/dN com propriedades mecânicas dos materiais, utilizando as equações (6) e (7) com as seguintes condições de contorno ${ }^{10}$ :

i) Prevalece um caso particular do estado plano de tensões, ou seja, o corpo é fixado num plano, mas é livre para expandir na direção perpendicular a este;

ii) O material é considerado isotrópico com um comportamento elasto-plástico ideal (não há encruamento);

iii) Todo o corpo passa de uma temperatura para outra instantaneamente, ou seja, não há gradiente térmico ao longo do corpo nas temperaturas consideradas.

Em cada direção do plano, a deformação total deste corpo causada por expansão ou contração decorrentes da variação cíclica entre uma temperatura menor,T1, e uma temperatura maior, T2 será

$$
\varepsilon_{t}=\alpha\left(T_{2}-T_{1}\right)
$$

Entretanto, de acordo com a condição (i), o corpo está fixado num plano; então, para cada direção naquele plano, $\varepsilon_{\mathrm{t}}$ deverá ser compensada por deformação elástica, $\varepsilon_{\mathrm{e}}$, e, se necessário, deformação plástica, $\varepsilon_{\mathrm{p}}$. Para cada direção nesse plano, a seguinte condição é válida ${ }^{10}$

$$
\varepsilon_{t}+\varepsilon_{e}+\varepsilon_{p}=0
$$

Aplicando a Lei de Hooke para um estado plano de tensões, as deformações elásticas desenvolvidas nas temperaturas mínima, $\varepsilon_{\mathrm{e} 1}$,e máxima, $\varepsilon_{\mathrm{e} 2}$, são: 


$$
\begin{aligned}
& \varepsilon_{e 1}=\frac{\left(1-v_{1}\right)}{E_{1}} \sigma_{1} \\
& \varepsilon_{e 2}=\frac{\left(1-v_{2}\right)}{E_{2}} \sigma_{2}
\end{aligned}
$$

em que $\sigma$ é o limite de escoamento do material do corpo, E é o módulo de elasticidade do material do corpo e $v$ é o coeficiente de Poisson do material do corpo e os índices 1 e 2 referem-se às temperaturas mínima e máxima, respectivamente.

A deformação plástica compressiva que ocorre no primeiro aquecimento, $\varepsilon_{\mathrm{p} 0}$, é obtida a partir das equações (8), (9) e (11):

$$
\varepsilon_{p 0}=\alpha\left(T_{2}-T_{1}\right)-\frac{\left(1-v_{2}\right)}{E_{2}} \sigma_{2}
$$

No resfriamento, a deformação plástica trativa, $\varepsilon_{\mathrm{p}}$, é dada pela equação

$$
\varepsilon_{p}=\alpha\left(T_{2}-T_{1}\right)-\frac{\left(1-v_{2}\right)}{E_{2}} \sigma_{2}-\frac{\left(1-v_{1}\right)}{E_{1}} \sigma_{1}
$$

No próximo ciclo de aquecimento, a deformação plástica compressiva será igual a $\varepsilon_{\mathrm{p}}$. O primeiro ciclo térmico é único, composto pela deformação plástica compressiva dada pela equação (12) e pela deformação plástica trativa dada pela equação (13). Os demais ciclos são idênticos, em que as deformações plásticas compressivas e trativas são iguais e dadas pela equação $(13)^{10}$.

Aplicando a equação (13) na equação de Coffin-Manson, o número de ciclos para a fratura é dado por ${ }^{10}$

$$
N_{f}=\left[\frac{C \varepsilon_{f 1}}{\alpha\left(T_{2}-T_{1}\right)-\frac{\left(1-v_{1}\right)}{E_{1}} \sigma_{1}-\frac{\left(1-v_{2}\right)}{E_{2}} \sigma_{2}}\right]^{\frac{1}{n}}
$$

Dado que o processo de fratura ocorre sob condições de tração, ou seja, à baixa temperatura $T_{1}$, selecionou-se o valor de $\varepsilon_{\mathrm{f}}$ referente à temperatura $T_{1}$.

Usando o mesmo procedimento anterior e aplicando a equação (13) na relação de Solomon, a taxa de propagação de trinca é dada por ${ }^{10}$ 


$$
\frac{d a}{d N}=p a\left[\alpha\left(T_{2}-T_{1}\right)-\frac{\left(1-v_{1}\right)}{E_{1}} \sigma_{1}-\frac{\left(1-v_{2}\right)}{E_{2}} \sigma_{2}\right]^{q}
$$

Os resultados experimentais obtidos no artigo foram razoavelmente coincidentes com os calculados pelo modelo da equação (14). Mas a equação (15) não pôde ser testada quantitativamente, apesar de dar indicações qualitativas sobre as propriedades importantes para diminuir a taxa de propagação de trinca, como elevada resistência a alta temperatura e resistência ao revenimento.

\subsubsection{Fadiga térmica em materiais frágeis}

O estudo do comportamento de materiais frágeis submetidos a fadiga térmica está concentrado na área de materiais cerâmicos, destacando-se o trabalho de Hasselman $^{14}{ }^{31}$. Com o desenvolvimento deste tópico, baseado totalmente neste trabalho de Hasselman, pretende-se registrar bases teóricas importantes para a discussão dos resultados experimentais desta dissertação, uma vez que os ferros fundidos brancos multicomponentes para cilindros apresentam comportamento macroscópico frágil mesmo sob temperaturas elevadas (da ordem de $500^{\circ} \mathrm{C}$ ).

Distinguem-se duas situações básicas: i) a fratura do componente é controlada pela nucleação de trincas (uma vez nucleada, a trinca propaga-se instavelmente por todo o componente); ii) a fratura do componente é controlada pela propagação de trincas (a propagação instável por todo o componente somente ocorre quando atingido um tamanho crítico).

No caso de materiais em que a fratura é controlada pela nucleação de trinca, a falha ocorre quando a tensão térmica excede o limite de ruptura do material ${ }^{9}$. Partindo das equações (3) e (4), a resistência do material à fratura pode ser definida pela mudança de temperatura que pode ser tolerada sem que ocorra fratura ${ }^{9,31}$. Assim,

$$
\Delta T=\frac{\sigma_{f}(1-v) k}{E \alpha c h}
$$

onde $\sigma_{f}$ é o limite de ruptura. Portanto, a resistência do material à fratura (nucleação de trinca), nesse caso, é favorecida por altos coeficiente de condutividade térmica e 
limite de ruptura e por baixos valores de módulo de elasticidade, coeficiente de expansão térmica e taxa de transferência de calor.

No caso de materiais em que a fratura é controlada pela propagação de trinca, esta depende da quantidade de energia disponível de deformação elástica na fratura e é inversamente proporcional à energia necessária para a criação de novas superfícies de fratura $^{31}$. A resistência do material à instabilidade da trinca pode ser descrita por um parâmetro $\mathrm{R}^{9,31}$ dado por

$$
R=\frac{E \gamma}{\sigma_{f}^{2}}(1-v)
$$

onde $\gamma$ é a energia de superfície de fratura. Nesse caso, a resistência à instabilidade de trinca é maximizada por altos valores de módulo de elasticidade e baixa resistência à fratura (oposto ao que acontece com a resistência à nucleação de trincas. equação 8) e independe das condições de troca térmica.

Também para esse caso, pode ser definida uma resistência do material à propagação instável de trinca dada pela variação máxima de temperatura $\left(\Delta \mathrm{T}_{\mathrm{c}}\right)$ que o componente pode suportar sem que haja essa propagação instável. Para o caso de uma chapa plana confinada, a diferença de temperatura crítica necessária para propagação simultânea de $\mathrm{N}$ trincas circulares de igual diâmetro(l) por unidade de volume, considerando que não há interação entre os campos de tensão de trincas vizinhas, é dada por

$$
\Delta T_{c}=\left(\frac{2 \gamma}{\pi l \alpha^{2} E}\right)^{0,5}\left(1+2 \pi N l^{2}\right)
$$

A figura $8^{31}$ mostra o comportamento de $\Delta \mathrm{T}_{\mathrm{c}}$ em função do comprimento inicial da trinca e da densidade de trincas. 


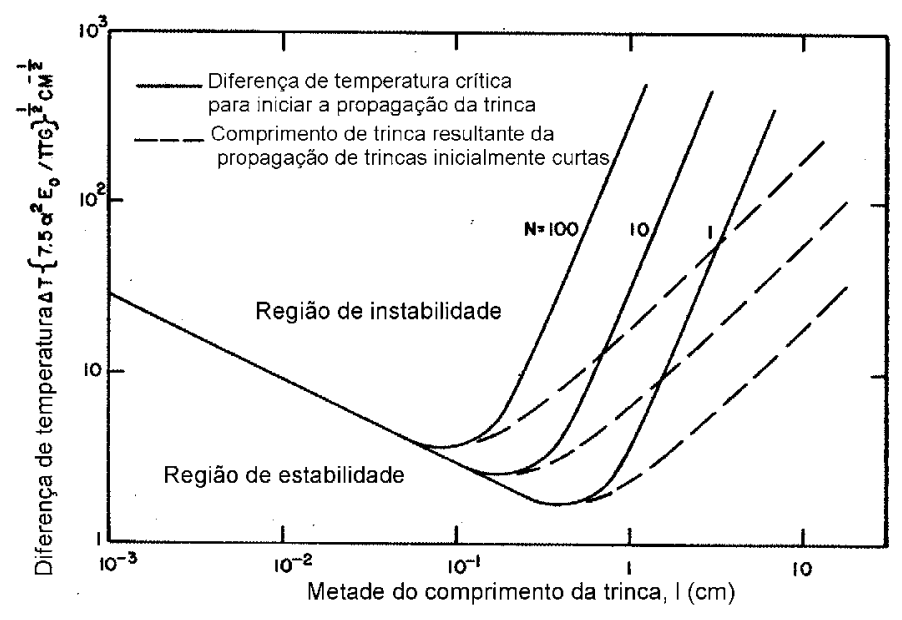

Figura 8 - Diferença de temperatura mínima requerida para iniciar propagação instável de trinca em função do comprimento inicial da trinca e da densidade de trincas $^{31}$.

Para trincas pequenas, $\Delta \mathrm{T}_{c}$ diminui com o aumento do comprimento da trinca. Isso significa que quando o comprimento inicial da trinca é pequeno, pequenas variações de temperatura são suficientes para promover a propagação instável dessas trincas; adicionalmente, à medida que essa propagação se dá (aumentando o comprimento da trinca), é cada vez menor a variação de temperatura necessária para promover a propagação instável. Isso ocorre porque a energia consumida para a formação de uma nova superfície de fratura (trinca) é menor do que a energia de deformação acumulada no componente e que deve ser aliviada. Esse excesso de energia de deformação é então transformado em energia cinética, agindo como força motora para a propagação da trinca. Quando esses dois termos de energia (energia de deformação acumulada no componente e energia para formação de uma nova superfície de fratura) são balanceados, a propagação da trinca é interrompida. Esse momento é representado pelo mínimo das curvas na figura $8^{31}$.

\subsubsection{Ensaios de fadiga térmica}

Os ensaios de fadiga térmica surgiram em meados dos anos 50, da necessidade de entender significativamente os fatores envolvidos na fadiga térmica de ligas destinadas ao trabalho a altas temperaturas. Essa necessidade ocorreu devido a sérios problemas de fadiga térmica em palhetas de turbina de aviões ${ }^{32}$. Em função 
de terem sido desenvolvidos para simular uma condição específica de trabalho (palhetas de turbina de aviões), não há padronização do ensaio quanto à geometria do corpo-de-prova e ciclo térmico (meios de aquecimento, temperaturas máxima e mínima do ciclo, entre outros). Ainda atualmente, os ensaios de fadiga térmica se destinam a simular condições de componentes expostos à variação cíclica de temperatura.

Além disso, em relação à influência do tipo de material sobre a resistência à fadiga térmica, os resultados da literatura são apresentados, em geral, na forma de uma análise comparativa entre ligas ${ }^{21,22,30}$, não havendo trabalhos mais sistemáticos correlacionando características microestruturais e resistência à fadiga térmica. No que diz respeito a variáveis de ensaio como ciclo térmico e geometria do corpo-deprova, alguns estudos mais sistemáticos foram realizados ${ }^{20,33,34,35}$, embora em pequena quantidade.

De uma forma geral, os parâmetros medidos nos ensaios de fadiga térmica são número, comprimento máximo e taxa de propagação de trincas e número de ciclos para a fratura, $\mathrm{N}_{f}$, que é determinado por meio de inspeções periódicas da superfície da amostra, até que uma trinca seja observada. Os problemas desse procedimento estão relacionados à periodicidade de observação da superfície, ao aumento utilizado durante a inspeção da superfície e ao critério utilizado para determinar o número de ciclos para a fratura (média aritmética entre o número de ciclos da inspeção anterior, $\mathrm{N}_{1}$, e o número de ciclos em que a trinca foi detectada, $\mathrm{N}_{2}$ ou, ainda, o próprio número de ciclos em que se detectou a trinca ${ }^{21,34,36}$ ). Nenhum desses fatores é padronizado e, em alguns casos, sequer mencionados. Bhattachar ${ }^{36}$, por exemplo, utiliza lentes de 40 e $25 \mathrm{X}$ de aumento durante as inspeções de superligas a base de níquel ensaiadas à fadiga térmica, ao passo que Glenny ${ }^{34}$, também ensaiando superligas a base de níquel, utiliza lentes de 30 e $60 \mathrm{X}$ de aumento nas inspeções.

Existem variáveis de ensaio na fadiga térmica cujas alterações afetam os resultados obtidos no ensaio. Essas variáveis podem ser divididas em duas categorias: 
i) Variáveis ligadas ao ciclo térmico do ensaio - taxas de aquecimento e resfriamento, temperaturas máxima e mínima do ciclo e tempo de permanência à temperatura máxima;

ii) Variáveis ligadas ao corpo-de-prova - tamanho e geometria.

1.2.5.1. Efeito de variáveis ligadas ao ciclo térmico sobre os resultados do ensaio Métodos de aquecimento e resfriamento

Os métodos de aquecimento utilizados em ensaios de fadiga térmica variam em função da aplicação que se pretende simular. Por exemplo, componentes que sofrem fadiga térmica em que o aquecimento é causado por contato direto com chama é simulado, no ensaio, com aquecimento por queimador ${ }^{20}$. Entretanto, os métodos mais utilizados são indução ${ }^{22,37,38}$ e leito fluidizado ${ }^{33,34}$. Outros métodos de aquecimento menos empregados são forno ${ }^{29,39}$ e soprador de ar quente ${ }^{36,40}$.

Os métodos de resfriamento normalmente utilizados são leito fluidizado ${ }^{33,34}$, água $^{29,37,39,40}$ ou ar ${ }^{20,36,41}$. Dentre esses, o resfriamento em água é o que promove as maiores tensões, visto que é o meio de resfriamento com maior capacidade de extração de calor, causando uma velocidade de resfriamento elevada e, conseqüentemente, um grande gradiente térmico.

Os métodos de aquecimento e resfriamento determinam as taxas de aquecimento e resfriamento impostas ao corpo-de-prova. Glenny ${ }^{34}$ verificou a influência das taxas de aquecimento e resfriamento sobre o número de ciclos para a fratura de superligas a base níquel, utilizando três tipos de ensaio: i) corpos-de-prova aquecidos lentamente por meio de uma resistência elétrica e então imersas em leitos fluidizados mantidos a $20^{\circ} \mathrm{C}$ para garantir um resfriamento rápido, ii) corpos-deprova aquecidos rapidamente em leitos fluidizados, mantidos a $920^{\circ} \mathrm{C}$ e então resfriados lentamente ao ar e iii) corpos-de-prova aquecidos e resfriados rapidamente por meio de imersão em leitos fluidizados a $920^{\circ} \mathrm{C}$ e $20^{\circ} \mathrm{C}$, respectivamente. Ele mostrou que taxa de aquecimento elevada diminui o número de ciclos para fratura quando comparado a taxa de resfriamento elevada, como mostra a figura 9. $\mathrm{Na}$ figura, $c, h$ e $h+c$ representam resfriamento rápido, aquecimento rápido $\mathrm{e}$ aquecimento e resfriamento rápidos, respectivamente. $\mathrm{O}$ efeito combinado de taxas 
de aquecimento e resfriamento elevadas é igual ou pior que o efeito provocado por taxa de aquecimento elevada.

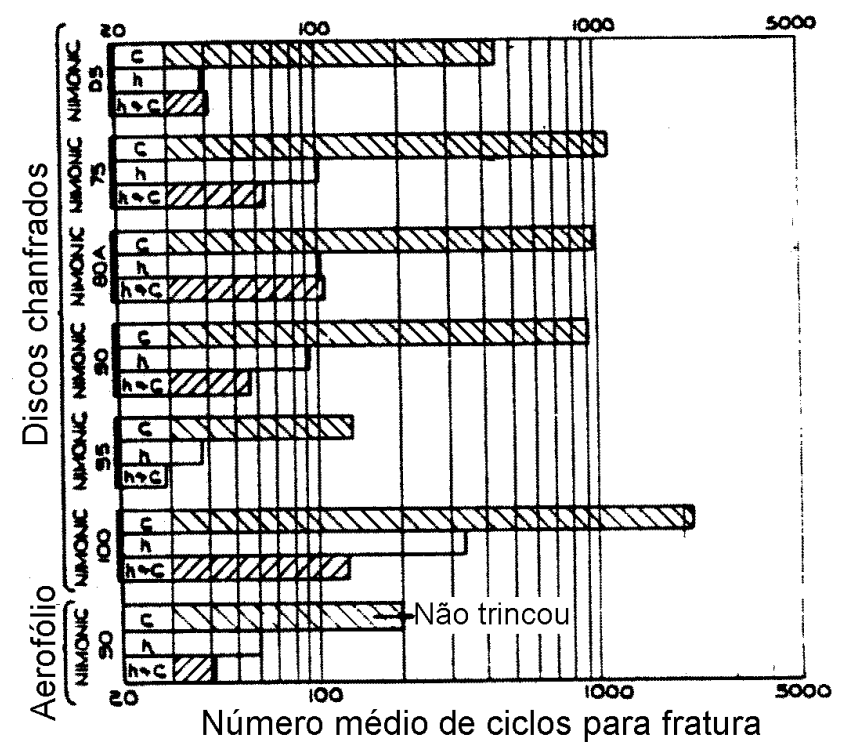

Figura 9 - Variação no número de ciclos para fratura de ligas a base de níquel em função da natureza do ciclo $^{34}$.

A explicação para esse resultado baseia-se no fato de que o aquecimento rápido produz um gradiente de tensão compressiva cuja intensidade, na superfície, é suficiente para causar deformação plástica. Em conseqüência, quando o corpo-deprova atinge uma temperatura uniforme, permanece, nas camadas superficiais, uma tensão residual de tração. Essa tensão residual de tração está presente na superfície do componente exposto à temperatura máxima, quando a resistência do material é baixa. Já quando o resfriamento é rápido, o gradiente máximo de tensão de tração se desenvolve a uma temperatura mais baixa, onde a resistência do material é maior ${ }^{34}$.

\section{Temperaturas máxima, $T_{2}$, e mínima, $T_{1}$, do ciclo}

A diferença de temperatura e, portanto, a magnitude das tensões térmica, é definida pelos valores de $\mathrm{T}_{\text {máx }}$ e $\mathrm{T}_{\text {mín }}$, mas, além disso, os próprios valores de $\mathrm{T}_{\text {máx }} \mathrm{e}$ $\mathrm{T}_{\text {mín }}$ são importantes, uma vez que propriedades mecânicas, resistência à oxidação e características metalúrgicas do material são dependentes da temperatura ${ }^{34}$. Quanto 
maior a temperatura $T_{2}$, menor o desempenho ${ }^{i}$ do material à fadiga térmica ${ }^{20,26,34}$. Isso ocorre em função da diminuição da resistência do material à medida que a temperatura aumenta.

Rezai-Aria $^{20}$, estudando a superliga MAR-M509, por meio de corpo-de-prova com geometria de cunha, mostrou que o aumento na temperatura máxima do ciclo, $\mathrm{T}_{2}$, aumenta a taxa de propagação de trinca, como mostra a figura 10.

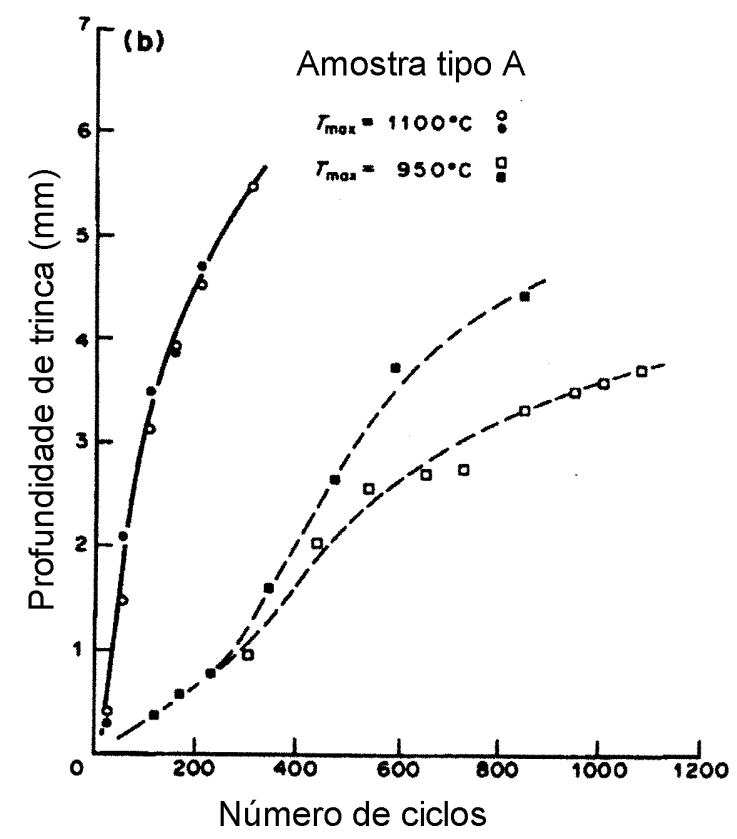

Figura 10 - Profundidade da maior trinca em função do número de ciclos para dois valores de temperatura $T_{2}$ (os pontos cheios e vazios para cada temperatura representam uma repetição do ensaio $)^{20}$.

Ele mostrou, ainda, que embora as trincas tenham nucleado rapidamente para as duas temperaturas utilizadas, a amostra submetida ao ciclo com maior temperatura máxima apresentou uma maior densidade de trincas secundárias (ele denomina trincas secundárias todas as trincas com exceção da maior trinca). Isso demonstra que a temperatura máxima afeta tanto a nucleação quanto a propagação de trincas.

Entretanto, acima de um valor crítico de temperatura, o desempenho do material à fadiga térmica aumenta com o aumento da temperatura ${ }^{22,34}$. Esse

\footnotetext{
i O termo desempenho será utilizado para expressar a resistência do material à fadiga térmica em função dos resultados serem apresentados por meio de parâmetros diferentes nos artigos.
} 
comportamento é atribuído a um aumento significativo da ductilidade do material, contrabalançando a perda de resistência ${ }^{34}$ e a mudanças microestruturais ${ }^{22}$.

Em relação à diferença entre as temperaturas máxima e mínima do ciclo, $\Delta \mathrm{T}$, seu aumento (mantendo $\mathrm{T}_{2}$ constante) diminui o desempenho do material sob fadiga térmica $^{22,34,35}$. Lee ${ }^{35}$ mostrou esse resultado para três ligas destinadas à fabricação de cilindros de laminação a quente: ferro fundido branco multicomponente, ferro fundido branco alto cromo e ferro fundido indefinido. Na figura 11, os três materiais apresentaram o mesmo comportamento, ou seja, um acréscimo no número de trincas superficiais com o aumento de $\Delta \mathrm{T}$.

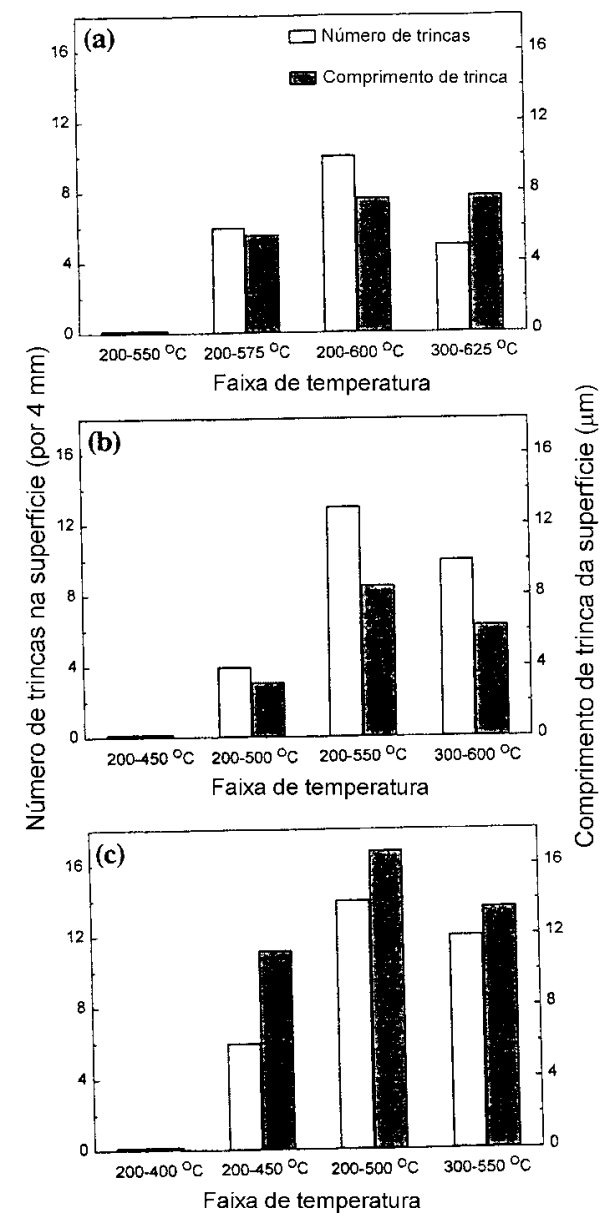

Figura 11 - Número de trincas formadas na superfície em função da variação de temperatura. (a) ferro fundido branco multicomponente, (b) ferro fundido branco alto cromo e (c) ferro fundido mesclado ${ }^{35}$. 
Tempo de permanência à temperatura máxima

$\mathrm{O}$ aumento no tempo de permanência à temperatura máxima diminui o desempenho do material sob fadiga térmica até um valor crítico, a partir do qual, há um aumento deste desmpenho ${ }^{22,34}$. Isto é explicado com base nas tensões trativas desenvolvidas durante o ciclo térmico. No aquecimento, desenvolvem-se tensões compressivas na superfície do corpo-de-prova que podem ser elevadas o suficiente para causar deformação plástica localizada e eliminar aquelas tensões compressivas. Se o corpo-de-prova é mantido à temperatura elevada por um tempo longo, a temperatura do interior do corpo-de-prova aumenta, causando a sua expansão e, em decorrência disto, submetendo a superfície a tensões de tração proporcionais a esta expansão (isto é, se o tempo não for suficiente para que o interior do corpo-de-prova atinja a temperatura $T_{2}$, a dilatação do interior do corpo-de-prova e as tensões de tração na superfície também serão menores).

Já o aumento do desempenho a partir de um tempo crítico de permanência é atribuído a mudanças microestruturais, como coalescimento da fase $\gamma^{\prime}\left(\mathrm{Ni}_{3}[\mathrm{Ti}, \mathrm{Al}]\right)$ e precipitação de carbonetos no caso de superligas a base de níquel ${ }^{22}$.

Glenny $^{34}$, estudando o comportamento de superligas a base de níquel sob fadiga térmica, mostrou que aumentando o tempo de permanência à temperatura $T_{2}$ até um valor crítico, diminuía o desempenho do material, como mostra a figura 12 . No trabalho de Glenny ${ }^{34}$, o tempo a partir do qual o comportamento se inverte foi de 60 segundos, o mesmo necessário para a equalização das temperaturas da superfície e do interior do corpo-de-prova. 


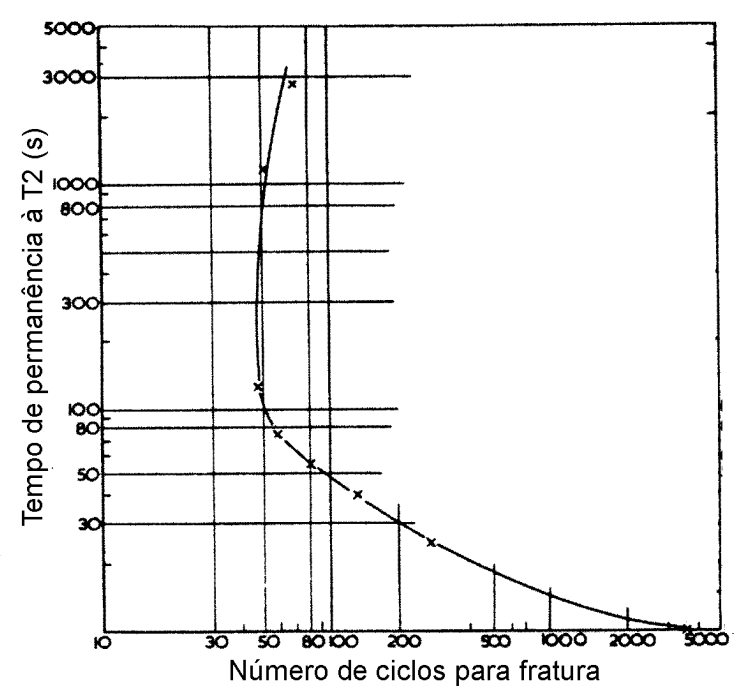

Figura 12 - Número de ciclos para a fratura em função do tempo de permanência à temperatura máxima ${ }^{34}$.

1.2.5.2. Efeito de variáveis ligadas ao corpo-de-prova sobre os resultados dos ensaios Geometria e tamanho do corpo-de-prova

Quanto maior o tamanho do corpo-de-prova, menor é o desempenho do material à fadiga térmica ${ }^{20,36}$. Isso resulta dos maiores gradientes térmicos (e conseqüentemente maiores tensões) desenvolvidas em corpos-de-prova de maiores dimensões (que impedem rápida homogeneização da temperatura do corpo-deprova).

O efeito da geometria do corpo-de-prova é tratado na literatura por meio de variação nos raios de curvatura de corpos-de-prova com geometrias de cunha e discos chanfrados. A diminuição do raio de curvatura diminui o desempenho do material sob fadiga térmica ${ }^{20,22,33}$.

Rezai-Aria $^{20}$, utilizando corpo-de-prova com geometria de cunha da superliga MAR-M509, visando reproduzir a geometria de pás de turbina, mostrou que o aumento do raio de curvatura aumenta o desempenho do material, como mostra a figura 13, em que o corpo-de-prova A possui menor raio de curvatura do que o B. 


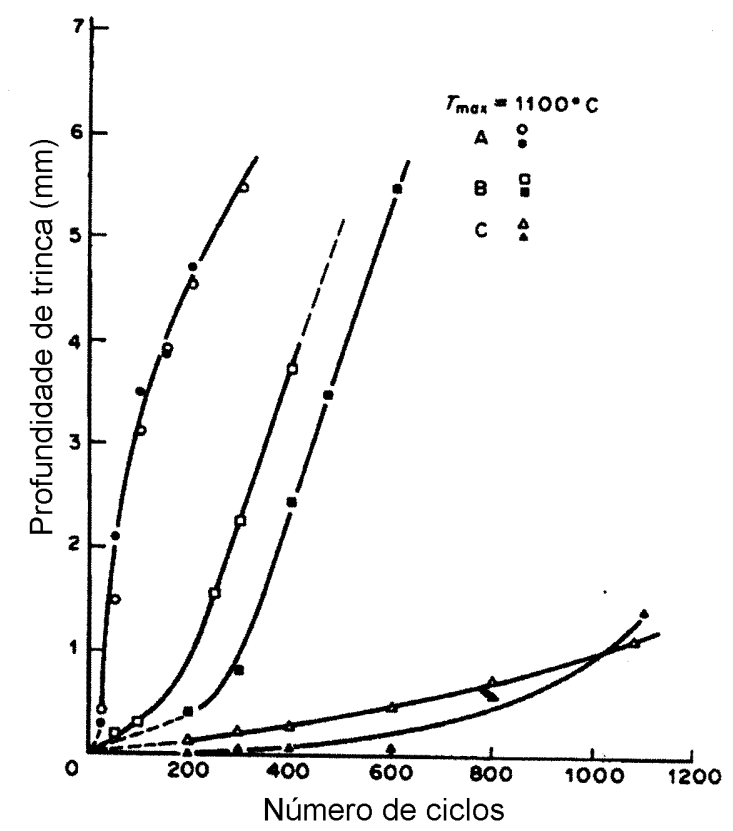

Figura 13 - Influência da geometria sobre a profundidade da maior trinca em função do número de ciclos (os pontos cheios e vazios para cada temperatura representam uma repetição do ensaio). A e B - corpos-de-prova com mesmo tamanho e diferentes raios de curvatura $\left(\mathrm{r}_{\mathrm{c}} \mathrm{A}<\mathrm{r}_{\mathrm{c}} \mathrm{B}\right)$ e $\mathbf{B}$ e $\mathbf{C}$ - corpos-de-prova com mesmo raio de curvatura e tamanhos diferentes $(\mathrm{C}>\mathrm{B})^{20}$.

Observou-se que, embora a nucleação de trincas ocorra rapidamente para todos os raios de curvatura, a taxa de propagação da trinca foi menor para a amostra com maior raio de curvatura. Isso ocorre devido à maior concentração de tensão causada pelo menor raio de curvatura.

De outro lado, considerando corpos-de-prova com mesmo raio de curvatura (B e C), o de maior tamanho apresentou pior desempenho (figura 13), ratificando o comportamento apontado anteriormente.

1.2.6. Correlação entre microestruturas brutas de fundição e desempenho em fadiga térmica

O efeito da microestrutura sobre a resistência à fadiga térmica é pouco abordada pela literatura, que se concentra em alguns aspectos microestruturais de 
superligas a base de níquel, como tamanho de grão, espaçamento dendrítico e carbonetos $^{16,20,21,22,34,36}$.

A nucleação de trincas de fadiga térmica em materiais no estado bruto de fundição com carboneto eutético ocorre na interface entre esses carbonetos e a matriz $^{21,22,23,24,35}$. A diferença entre os coeficientes de expansão térmica do carboneto e da matriz, bem como a baixa ductilidade do carboneto, facilita a nucleação de uma trinca na interface carboneto/matriz, segundo o mecanismo discutido no tópico 1.2.1. Nos materiais que não possuem carbonetos, ou possuem-nos em fração muito pequena, a nucleação ocorre nos contornos de grão ${ }^{22,23}$. Há ainda um fator importante a se considerar nesse processo que é a oxidação que ocorre durante a exposição às altas temperaturas envolvidas. A oxidação diminui o teor de elementos de liga da matriz, diminuindo sua resistência e favorecendo, portanto, a deformação plástica dessas áreas. Se esse fenômeno é associado às diferenças entre os coeficientes de expansão, o processo de fadiga térmica pode ser acelerado.

Beck e Santhanam ${ }^{21}$, estudando a resistência à fadiga térmica da superliga MAR-M509 no estado bruto de fundição, verificaram a nucleação de trincas preferencialmente nos carbonetos eutéticos interdendríticos e raramente nos contornos de grão, indicando que a presença de carbonetos tem um efeito mais prejudicial sobre o desempenho do material do que os contornos de grão.

Os resultados da literatura a respeito do efeito do tamanho de grão sobre o desempenho sob fadiga térmica não são concordantes. Beck e Santhanam ${ }^{21}$ não encontraram correlação entre o tamanho de grão e o desempenho sob fadiga térmica daquela liga. Entretanto, outros resultados da literatura mostram que a diminuição do tamanho de grão aumenta o desempenho do material sob fadiga térmica por meio de um aumento no número de ciclos para iniciar a fratura (nuclear a trinca) ${ }^{22,30}$. Woodford e Mowbray ${ }^{23}$ mostraram esse resultado em seu trabalho sobre a resistência à fadiga térmica de superligas fundidas, como mostra a figura 14 . 


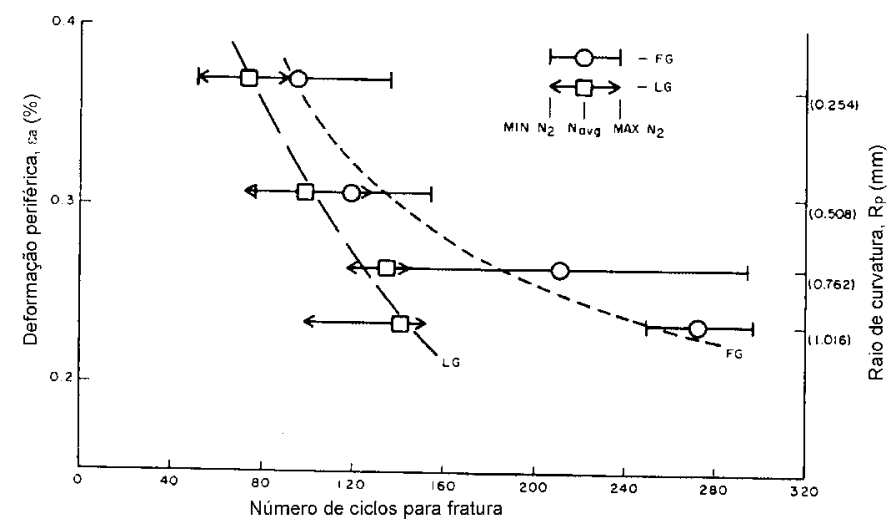

Figura 14 - Efeito do tamanho de grão sobre o número de ciclos para nuclear trinca na superliga IN-738. FG - grão fino e LG - grão grosseiro ${ }^{23}$.

Por outro lado, no que diz respeito à propagação de trincas, o efeito do tamanho de grão se inverte: a resistência à propagação da trinca é favorecida pelo aumento do tamanho de grão ${ }^{23}$, como mostra a figura 15 .

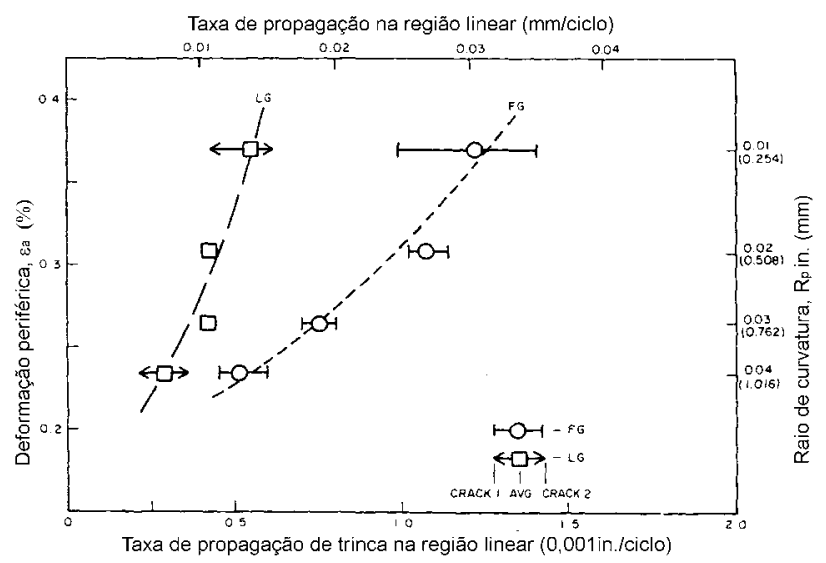

Figura 15 - Efeito do tamanho de grão sobre a taxa de propagação de trinca da superliga IN-738. FG - grão fino e LG - grão grosseiro ${ }^{23}$.

Esse comportamento se deve ao alinhamento de carbonetos. $\mathrm{Na}$ amostra com maior tamanho de grão, os carbonetos estavam alinhados numa direção perpendicular à direção de propagação da trinca, ao passo que o alinhamento de carbonetos na amostra com menor tamanho de grão ocorreu numa direção com poucos graus de 
diferença em relação à direção de propagação da trinca ${ }^{22}$. Esse resultado confirma a maior importância dos carbonetos do que dos contornos de grão sobre o desempenho do material sob fadiga térmica.

Em relação ao espaçamento dendrítico, os resultados mostram que a diminuição do espaçamento interdendrítico aumenta as cinéticas de nucleação e propagação das trincas ${ }^{21}$. Beck e Santhanam mostraram esse efeito do espaçamento dendrítico sobre o número de ciclos para iniciar a fratura na figura 16 e sobre a taxa de propagação inicial da trinca na figura $17^{21}$.

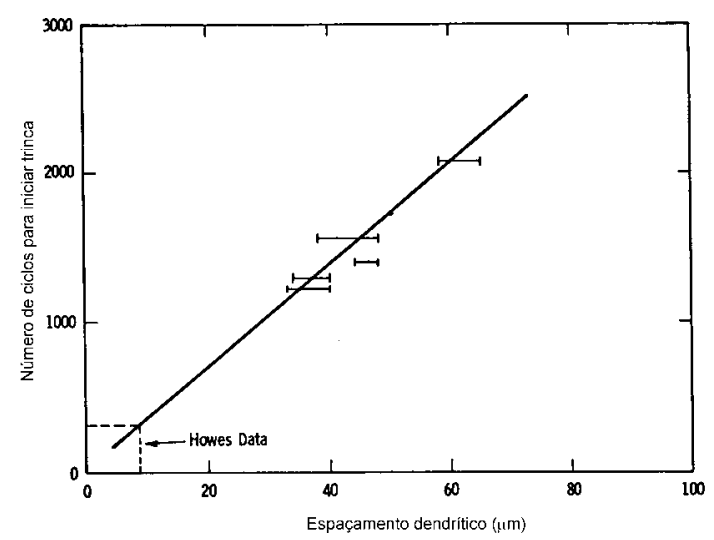

Figura 16 - Efeito do espaçamento dendrítico no número de trincas para a fratura da liga MAR-M509 ${ }^{21}$.

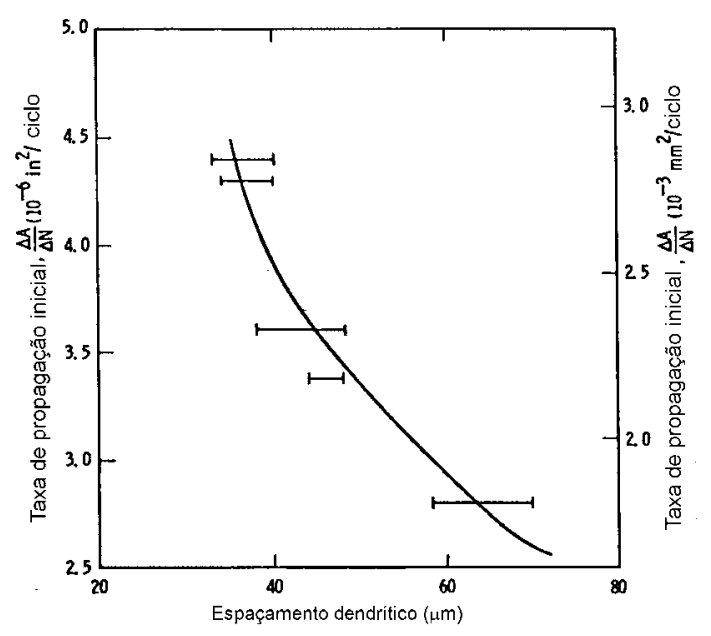

Figura 17 - Efeito do espaçamento dendrítico na taxa inicial de propagação da trinca para a liga MAR-M509²1. 
Entretanto, vale destacar que este trabalho utilizou um intervalo de espaçamento interdendrítico pequeno (entre 40 e $70 \mu \mathrm{m}$ aproximadamente). Além disso, a variação do número de ciclos para iniciar a fratura e da taxa de propagação de trinca causada por este intervalo de espaçamento interdendrítico também foi pequena.

1.2.7. Fadiga térmica e microestrutura dos ferros fundidos brancos multicomponentes para cilindros de laminação

A idéia de empregar ligas deste sistema resultou da percepção de que os requisitos para este tipo de aplicação- basicamente, resistência a desgaste e capacidade de reter elevada dureza mesmo quando submetido a altas temperaturassão atendidos pelos aços rápidos classicamente empregados na fabricação de ferramentas de corte. O projeto de liga tem como base o aço AISI M2; aproveitando o fato de o cilindro ser conformado por fundição, aumentaram-se os teores de carbono e vanádio objetivando aumentar a fração volumétrica de carbonetos MC.

A seqüência de solidificação dos ferros fundidos brancos multicomponentes para cilindros pode ser descrita pelas seguintes reações ${ }^{42}$ :

i) formação de austenita primária;

ii) decomposição eutética do líquido residual: $\mathrm{L} \rightarrow \gamma+$ carbonetos; a composição do líquido residual é continuamente alterada à medida que diminui a temperatura ("calha" eutética), provocando a formação de até 3 tipos de eutéticos: $\gamma+\mathrm{MC}, \gamma+\mathrm{M}_{2} \mathrm{C}$ e $\gamma+\mathrm{M}_{7} \mathrm{C}_{3}$.

Uma vez que a solidificação inicia pela formação de dendritas de austenita, a formação dos carbonetos eutéticos ocorre, em geral, nas regiões interdendríticas. Devido à segregação do soluto durante o crescimento da dendrita, há um enriquecimento do líquido residual até que a sua composição atinja a composição eutética. O eutético $\gamma+\mathrm{MC}$ sempre é o primeiro a precipitar, devido aos elevados teores de vanádio destas ligas ${ }^{43}$.

A seqüência de precipitação dos demais eutéticos depende principalmente da composição química: o eutético $\gamma+\mathrm{M}_{2} \mathrm{C}$ é favorecido por $\mathrm{W}$, Mo e $\mathrm{V}$, enquanto o eutético $\mathrm{M}_{7} \mathrm{C}_{3}$ é favorecido por Cr e C. A fração volumétrica de carbonetos eutéticos pode variar entre $8 \%$ e $15 \%{ }^{42,43,44}$. 
A tabela 2 mostra os tipos de carbonetos eutéticos presentes na microestrutura dos ferros fundidos brancos multicomponentes e seus respectivos valores de dureza $^{45}$.

Tabela 2 - Carbonetos eutéticos típicos presentes na microestrutura dos ferros fundidos brancos multicomponentes para cilindros de laminação a quente e seus respectivos valores de dureza

\begin{tabular}{|l|l|}
\hline Carboneto & Dureza (HV) \\
\hline MC & 3000 \\
\hline M2C & 2500 \\
\hline M7C3 & $1300-1800$ \\
\hline
\end{tabular}

A microestrutura bruta de fundição possui matriz com produtos de decomposição da austenita (normalmente martensita ou bainita) e alguma austenita retida, carbonetos secundários globulares precipitados na matriz e carbonetos eutéticos constituindo células eutéticas ou distribuídos em regiões interdendríticas. A figura 18 mostra a microestrutura típica de um ferro fundido branco multicomponente para cilindro.

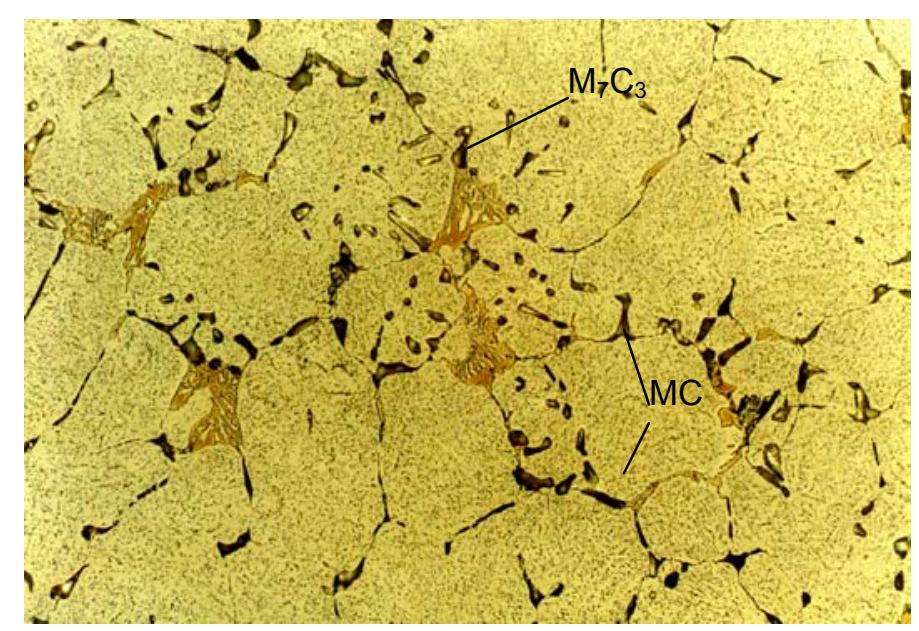

Figura 18- Microestrutura da liga Fe-7Cr-2Mo-2W-4V-1,6C. (400X).

As propriedades físicas que exercem influência direta sobre o comportamento dos materiais submetidos a solicitações de fadiga térmica- coeficiente de dilatação e 
condutividade térmica- não são alteradas em decorrência de modificações da composição química dos ferros fundidos brancos multicomponentes, ao contrário do que ocorre com a microestrutura destas ligas. Esta microestrutura, por sua vez, exerce influência importante sobre a nucleação e o crescimento de trincas de fadiga térmica $^{46}$.

No estudo da influência da microestrutura sobre a fadiga térmica durante a aplicação, a análise da seção transversal dos cilindros é fundamental para se verificar a propagação das trincas térmicas. O ideal, portanto, para avaliar o comportamento de um material para cilindro sujeito às condições de laminação seria obter amostras de cilindros provenientes de diferentes condições de laminação. Entretanto, isso resultaria em corte e sucateamento de cilindros em perfeitas condições de utilização, inviabilizando o procedimento. A literatura aborda o problema, portanto, de duas formas distintas: estudo da microestrutura de cilindros de trabalho que tenham quebrado em serviço e, conseqüentemente, tenham sido sucateados ${ }^{8,47,48}$ e por meio de ensaios que simulam a variação cíclica da temperatura da superfície de cilindros de laminação a quente ${ }^{37,46,52}$ ou a condição de laminação ${ }^{49,50,51}$ ou ainda fadiga termo-mecânica. Nos caso de ensaios de fadiga térmica, os resultados expressam correlações entre características quantitativas das trincas térmicas, como profundidade e densidade, e características qualitativas da microestrutura, como tipo e morfologia dos carbonetos eutéticos.

Os resultados destes estudos mostram que os carbonetos eutéticos cumprem um papel importante no processo de fadiga térmica, pois as trincas nucleiam nestes carbonetos e propagam-se ao longo da interface matriz/carboneto ${ }^{46,50,51,52}$. Pela equação (5), apresentada no tópico 1.2.1, é possível associar a estrutura de compósitos à microestrutura de aços contendo elevada fração volumétrica de carbonetos, como por exemplo os ferros fundidos brancos multicomponentes, uma vez que ambos consistem de partículas duras dispersas numa matriz mais tenaz. Então, pela figura $19^{9}$, que mostra os valores de expansão térmica para alguns metais, carbonetos e boretos em função de seu ponto de fusão, destaca-se a diferença entre os coeficientes de expansão térmica do ferro (embora a matriz dos ferros fundidos brancos multicomponentes possua um elevado teor de elementos de liga 
dissolvidos, é possível fazer esta aproximação) e dos carbonetos do tipo MC (VC, $\mathrm{MoC}, \mathrm{WC})$.

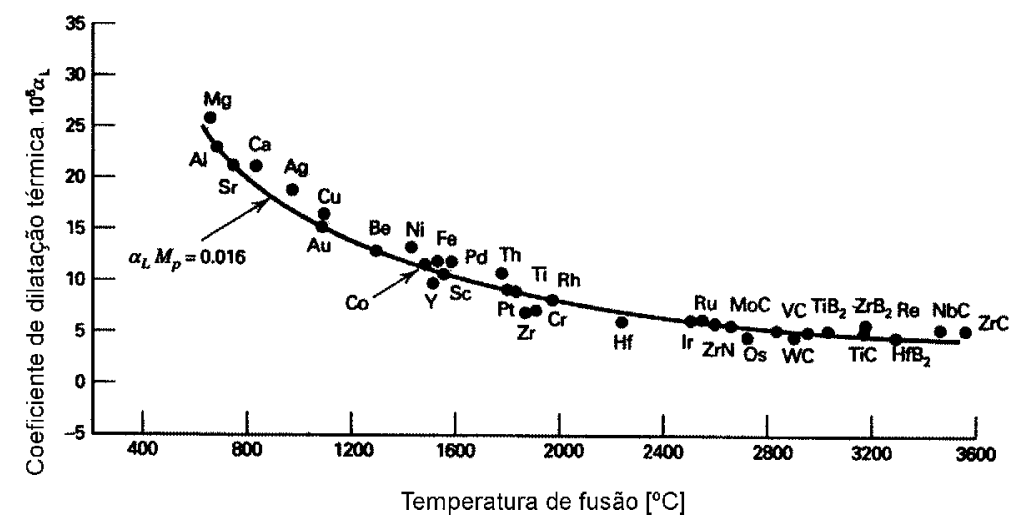

Figura 19 - Relação entre o coeficiente de expansão térmica e o ponto de fusão de metais, carbonetos e boretos com estruturas compactas ${ }^{9}$.

Além disto, a cinética de crescimento das trincas é tanto menor quanto maior a densidade das mesmas (isto é, quanto maior a cinética de nucleação) ${ }^{46}$. Dado que a presença de carbonetos eutéticos e, conseqüentemente, a nucleação das trincas são inevitáveis, conclui-se que a melhoria da resistência à fadiga térmica dos ferros fundidos brancos multicomponentes está ligada à obtenção de carbonetos eutéticos de pequeno tamanho e homogeneamente distribuídos, evitando a formação de carbonetos contínuos que facilitem a propagação das trincas térmicas ${ }^{46}$.

É importante observar que a abordagem dos trabalhos publicados limita-se a comparações entre ligas pertencentes à família dos ferros fundidos brancos multicomponentes ou entre um ferro fundido branco multicomponente e outra liga (ferro fundido branco de alto cromo, por exemplo). Não há estudos abordando de forma sistemática a influência de fatores como tipo e fração volumétrica de carbonetos eutéticos e propriedades mecânicas da matriz, entre outros. 


\section{OBJETIVOS DO TRABALHO}

O presente trabalho de mestrado propõe uma abordagem básica e sistemática investigando o efeito dos constituintes microestruturais de ferros fundidos brancos multicomponentes (ligas Fe-Cr-V-Mo-W-C) sobre seu comportamento sob fadiga térmica. Surpreendentemente, não se identificou este tipo de abordagem na literatura internacional, talvez pelo caráter tecnológico que tem sido imprimido aos trabalhos até então.

O trabalho experimental constituiu-se de 3 séries de experiências.

$\mathrm{Na}$ primeira série de experiências, foram estudados os efeitos da fração volumétrica do carboneto eutético MC e da resistência mecânica da matriz o comportamento sob fadiga térmica. Verificou-se, em trabalho anterior ${ }^{53}$, que a variação do teor de vanádio entre $5 \%$ e $8 \%$ promove variação da fração volumétrica do carboneto eutético MC em intervalo suficientemente amplo para estudar o efeito desta variável. A fração volumétrica de carbonetos intercelulares $\mathrm{M}_{2} \mathrm{C}$ e/ou $\mathrm{M}_{7} \mathrm{C}_{3}$, por outro lado, não varia significativamente, permanecendo em torno de $2 \%$. Adicionalmente, produziu-se uma liga isenta de carbonetos eutéticos e com composição química equivalente à da matriz das demais ligas.

A variação da resistência mecânica da matriz foi promovida por meio de tratamento térmico de revenimento. Verificou-se, em trabalho anterior ${ }^{54}$, que a variação da temperatura de revenimento entre $520^{\circ} \mathrm{C}$ e $620^{\circ} \mathrm{C}$ promove variação de dureza entre $55 \mathrm{HR}_{\mathrm{C}}$ e $45 \mathrm{HR}_{\mathrm{C}}$, aproximadamente, também um intervalo suficientemente amplo para estudar o efeito da resistência mecânica.

Na segunda série de experiências, estudou-se o efeito da fração volumétrica dos carbonetos eutéticos intercelulares $\mathrm{M}_{2} \mathrm{C}$ e/ou $\mathrm{M}_{7} \mathrm{C}_{3}$ sobre o comportamento sob fadiga térmica.

Verificou-se, em trabalho anterior ${ }^{55}$, que a variação do teor de molibdênio entre $2 \%$ e $5 \%$ promove variação da fração volumétrica do carboneto eutético intercelular $\mathrm{M}_{2} \mathrm{C}$ em intervalo suficientemente amplo para estudar o efeito desta variável.

$\mathrm{Na}$ terceira série, estudou-se o efeito do tamanho do corpo-de-prova sobre o comportamento sob fadiga térmica das ligas com $5 \%$ e $8 \%$ de vanádio. 
Em todas as séries de experiências, o comportamento sob fadiga térmica foi avaliado por meio de ensaio de fadiga térmica por 100 e 500 ciclos, conduzido em equipamento específico disponível no Laboratório de Fundição da Divisão de Metalurgia do IPT. Mediram-se a quantidade e a profundidade máxima das trincas de fadiga térmica. 


\section{MATERIAIS E MÉTODOS}

\subsection{Obtenção dos corpos-de-prova para os ensaios de fadiga térmica}

Os corpos-de-prova para ensaios de fadiga térmica não são normalizados. A julgar pelos dados disponíveis na literatura, há dois tipos de corpos-de-prova normalmente empregados nos estudos de fadiga térmica: disco com seção variável e cilindro com furo interno. O primeiro reproduz a geometria de palhetas de turbina e é classicamente empregado no estudo de ligas para esta aplicação. O segundo tem sido empregado no estudo de materiais para cilindros de laminação, pois reproduz sua geometria e facilita o tratamento matemático da solicitação por fadiga térmica.

Experimentos preliminares demonstraram que o emprego de disco com seção variável implica custosas operações de usinagem e controle para a reprodução do raio de curvatura da extremidade, enquanto o desenvolvimento de trincas mensuráveis no corpo-de-prova cilíndrico requer a aplicação de grande número de ciclos térmicos. Desta forma, optou-se por empregar uma geometria gerada pela combinação daqueles dois tipos, com os seguintes benefícios: facilidade de reproduzir e controlar a superfície periférica (denominada "pista"); impor gradiente térmico elevado ao longo de sua seção radial, de tal forma a permitir a formação de trincas mensuráveis após o número de ciclos planejados.

Este corpo-de-prova foi desenvolvido por uma empresa ex-fabricante de cilindros de laminação (Kantoc - Japão) e suas geometrias e dimensões são mostradas na figura 20. O corpo-de-prova da figura $20 \mathrm{~b}$ foi empregado somente na terceira série de experimentos. 


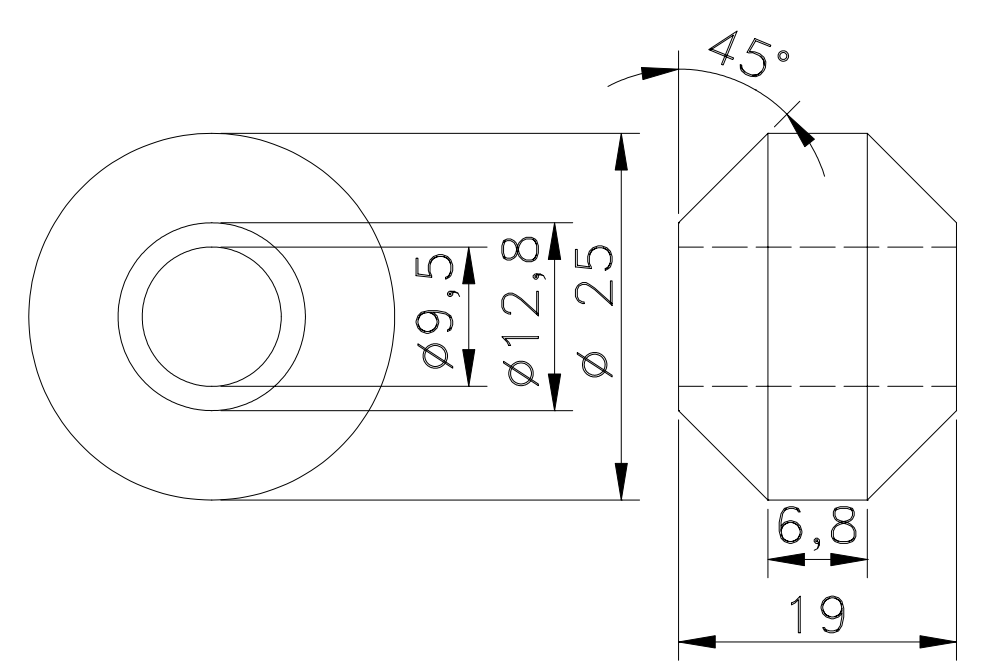

(a)

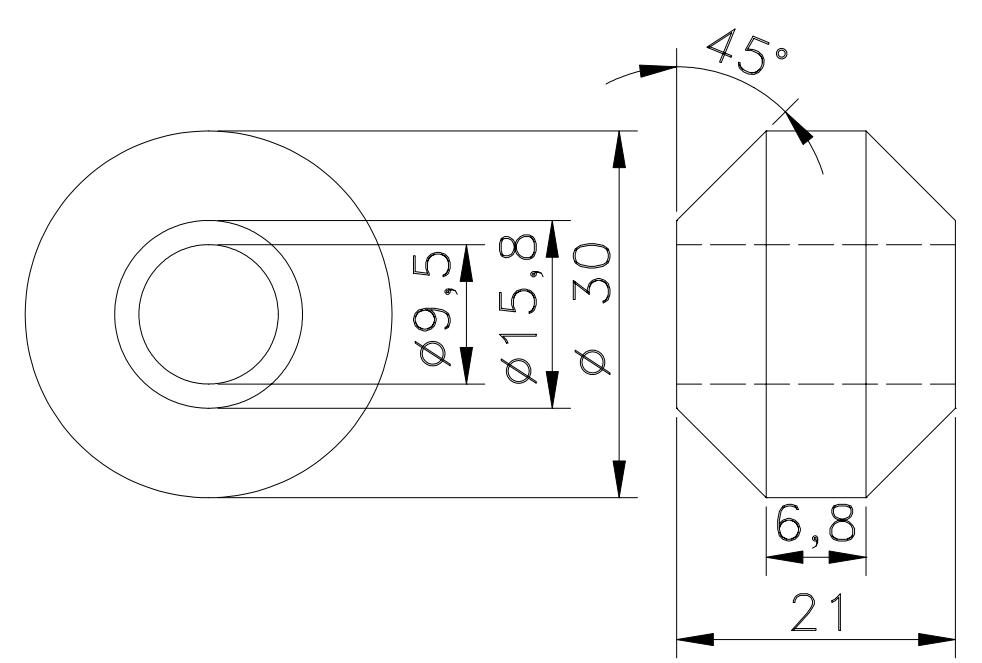

(b)

Figura 20 - Geometria e dimensões finais dos corpos-de-prova para ensaio de fadiga térmica (medidas em $\mathrm{mm}$ ).

As etapas de processamento dos corpos-de-prova foram fundição dos semiacabados, corte e usinagem, tratamentos térmicos, ensaios de controle e condicionamento final.

\section{a) Fundição dos semi-acabados}

A matéria-prima para a fundição dos semi-acabados consistiu de uma pré-liga elaborada em forno de indução a partir de sucata de aço ao carbono, ferroligas e grafita. As adições de vanádio ou molibdênio para a obtenção das composições objetivadas, bem como as adições dos demais elementos para compensar a diluição 
provocada pela adição de vanádio ou molibdênio e algumas perdas inerentes à refusão da pré-liga, foram efetuadas por meio de ferroligas e grafita.

As corridas foram conduzidas em forno de indução com refratário de alumina e "cortina" de argônio sobre a superfície do banho metálico para minimizar perdas por oxidação e volatilização. As temperaturas de vazamento das corridas foram determinadas a fim de se obter o mesmo superaquecimento para todas as ligas. Visto que a variação dos teores de vanádio e de molibdênio não causa alteração significativa da temperatura liquidus das $\operatorname{ligas}^{56}$, a temperatura de vazamento foi fixada em $1450^{\circ} \mathrm{C}$ para todas as ligas (superaquecimento de $100^{\circ} \mathrm{C}$ ). Cada corrida de $15 \mathrm{~kg}$ deu origem a 9 cilindros com $35 \mathrm{~mm}$ diâmetro e $100 \mathrm{~mm}$ de comprimento.

Os cilindros foram obtidos a partir de vazamento em molde cerâmico à temperatura ambiente. A velocidade de resfriamento média do fundido foi determinada por meio de termopar posicionado no interior do molde a 7,5 $\mathrm{mm}$ de sua superfície ("meio-raio") e, na faixa de temperatura de $1385^{\circ} \mathrm{C}$ a $1150^{\circ} \mathrm{C}$, é da ordem de $1,2^{\circ} \mathrm{C} / \mathrm{s}$ (similar à velocidade de resfriamento da "casca" de cilindros de laminação fundidas por centrifugação ${ }^{57}$ ). A figura 21 mostra o arranjo experimental utilizado para o vazamento dos semi-acabados.

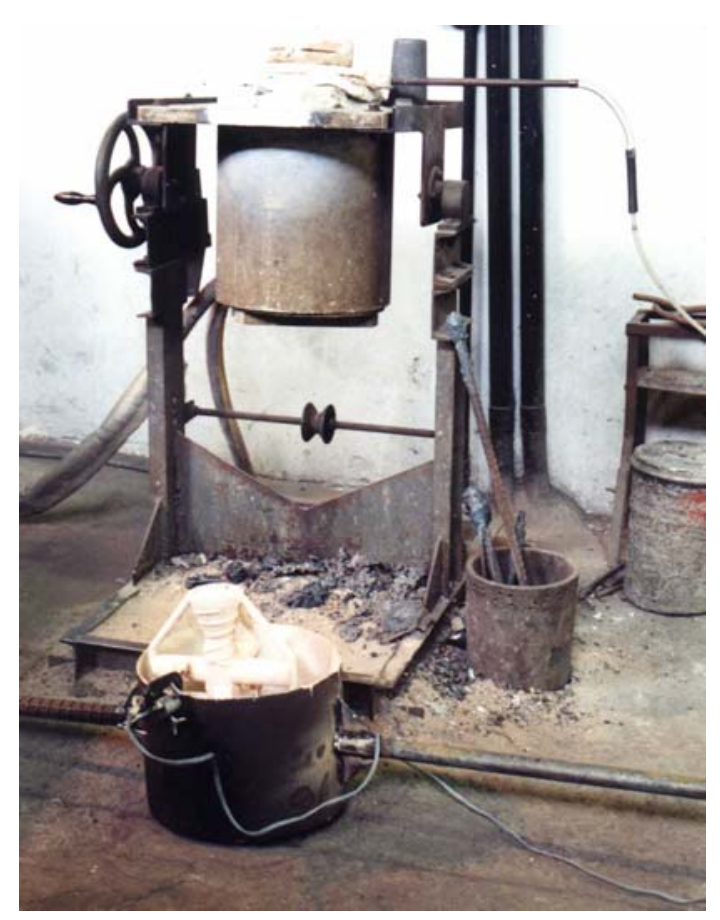

Figura 21 - Arranjo experimental utilizado para a fundição dos semi-acabados. 
Adicionalmente foram obtidos outros dois tipos de amostra: i) "varetas" para análise de carbono via combustão e ii) "bolacha" para análise dos demais elementos via espectrometria de fluorescência de raios $X$.

As tabelas 3 e 4 mostram a composição química das ligas obtidas.

Tabela 3- Composição química das ligas da $1^{\mathrm{a}}$ série de experiências

\begin{tabular}{|c|c|c|c|c|c|}
\hline \multirow{2}{*}{ Liga } & \multicolumn{5}{|c|}{ Composição química (\% em peso) } \\
\cline { 2 - 6 } & $\mathrm{C}$ & $\mathrm{V}$ & $\mathrm{W}$ & $\mathrm{Mo}$ & $\mathrm{Cr}$ \\
\hline $\mathrm{AM}$ & 0,55 & 0,88 & 1,19 & 1,40 & 2,73 \\
\hline V5 & 1,91 & 4,79 & 1,96 & 2,02 & 4,06 \\
\hline V6,5 & 2,00 & 6,52 & 2,02 & 2,03 & 4,07 \\
\hline V8 & 1,94 & 8,09 & 2,02 & 2,07 & 4,19 \\
\hline
\end{tabular}

Tabela 4 - Composição química das ligas da $2^{\mathrm{a}}$ série de experiências

\begin{tabular}{|c|c|c|c|c|c|}
\hline \multirow{2}{*}{ Liga } & \multicolumn{5}{|c|}{ Composição química (\% em peso) } \\
\cline { 2 - 6 } & $\mathrm{C}$ & $\mathrm{V}$ & $\mathrm{W}$ & $\mathrm{Mo}$ & $\mathrm{Cr}$ \\
\hline $\mathrm{AM}$ & 0,55 & 0,88 & 1,19 & 1,4 & 2,73 \\
\hline M2 & 2,00 & 8,16 & 2,10 & 2,01 & 4,18 \\
\hline M3,5 & 1,99 & 7,54 & 2,02 & 3,53 & 4,45 \\
\hline M5 & 1,97 & 8,27 & 2,09 & 4,93 & 3,75 \\
\hline
\end{tabular}

\section{b) Corte e usinagem de desbaste}

Para facilitar o processo de corte dos semi-acabados e possibilitar a usinagem dos corpos-de-prova, os cilindros foram recozidos a $850^{\circ} \mathrm{C}$ por 5 horas. Adicionalmente, este tratamento promoveu a homogeneização da microestrutura da matriz das ligas (figura 22). 


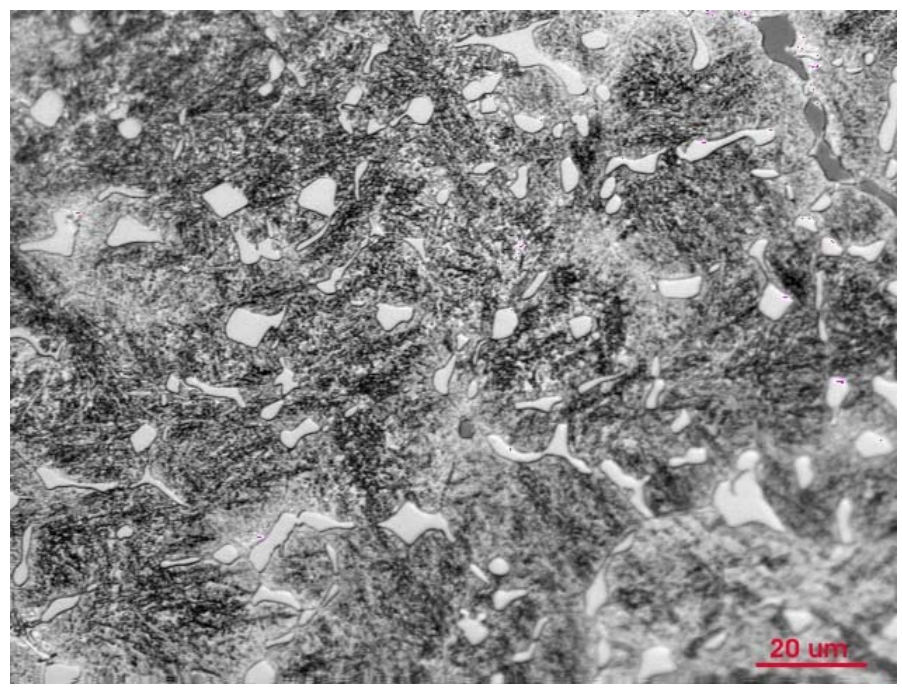

(a)

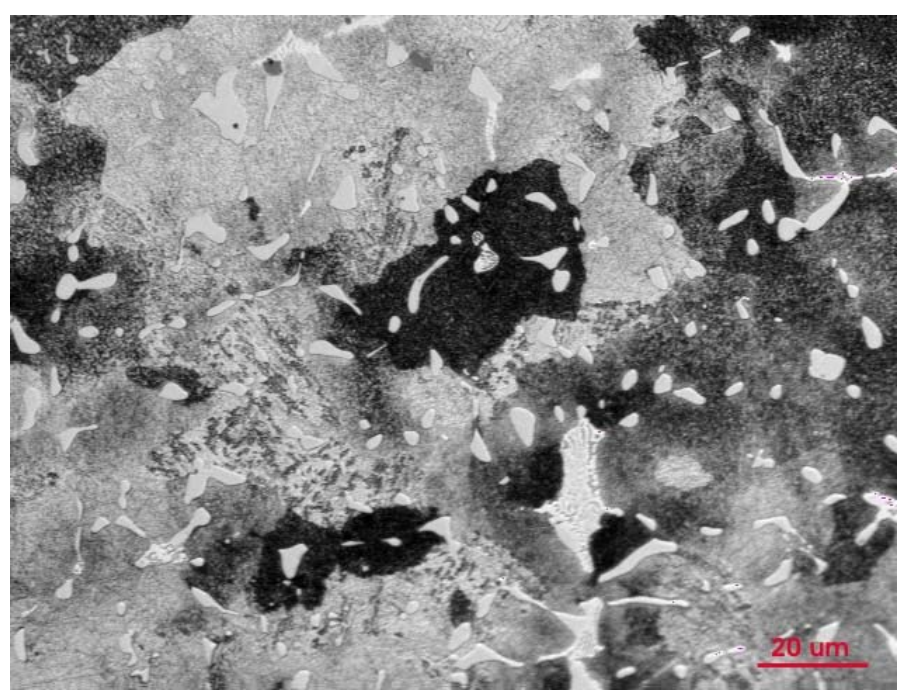

(b)

Figura 22 - Microestruturas da liga V8: (a) bruta de fundição e (b) recozida a $850^{\circ} \mathrm{C}$ por 5 horas.

Uma vez recozidos, os cilindros foram cortados, segundo o esquema apresentado na figura 23, a fim de adequar as amostras à operação subseqüente de usinagem de desbaste por torneamento e descartar as extremidades (evitando "efeitos de bordas"). Na usinagem de desbaste, conformou-se a geometria do corpo-de-prova com um sobremetal de $0,3 \mathrm{~mm}$ para eliminação na usinagem final. 


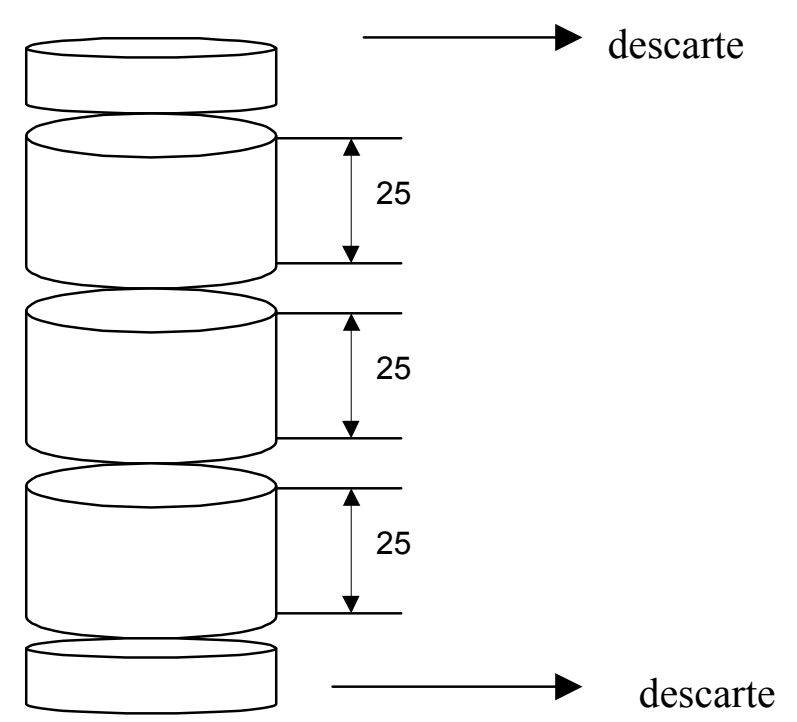

Figura 23 - Esquema de corte dos semi-acabados fundidos.

\section{c) Tratamentos térmicos}

A figura 24 mostra, esquematicamente, o ciclo de tratamento térmico a que foram submetidos os corpos-de-prova.

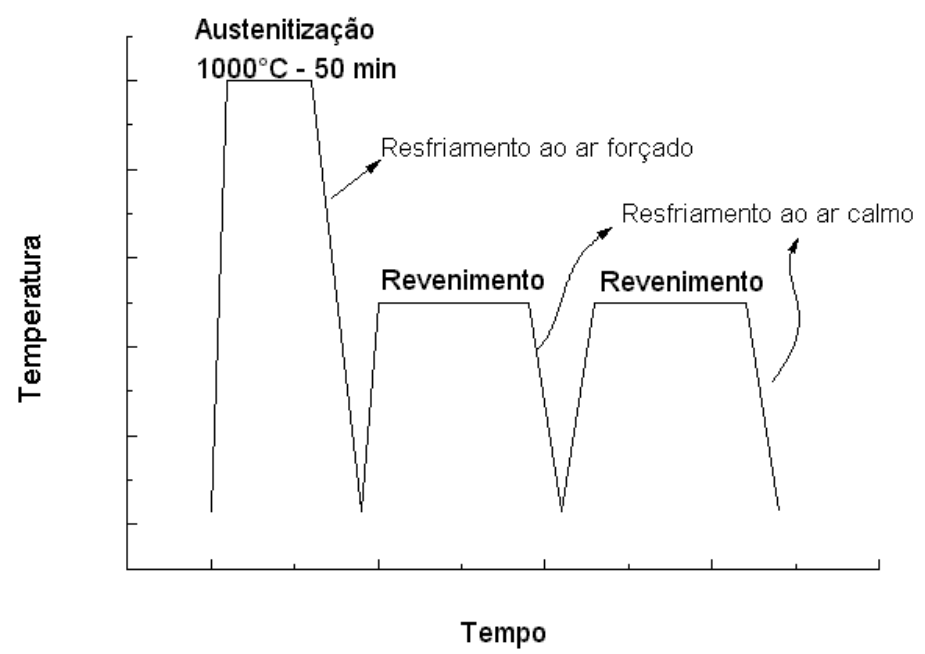

Figura 24 - Representação esquemática do ciclo de tratamento térmico a que foram submetidos os corpos-de-prova.

Os corpos-de-prova da liga AM passaram por um tratamento adicional para dissolução de carbonetos eutéticos, precipitados em contornos de grão em decorrência de segregação. $\mathrm{O}$ ciclo aplicado consistiu de aquecimento a $1250^{\circ} \mathrm{C}$ por 
2 horas seguido de resfriamento ao ar. A figura 25 mostra as microestruturas bruta de fundição e pré-tratada.

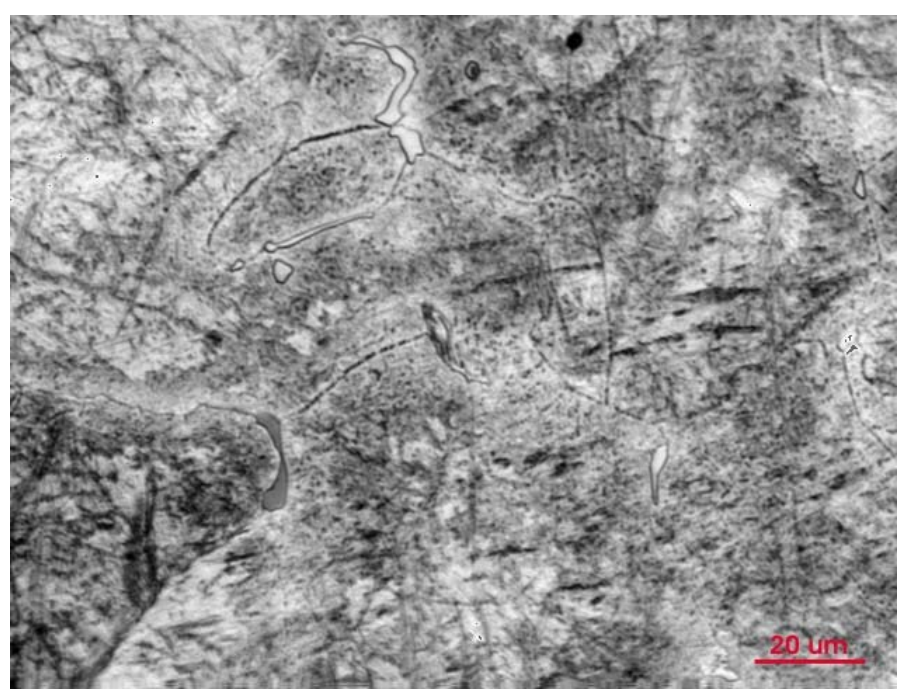

(a)

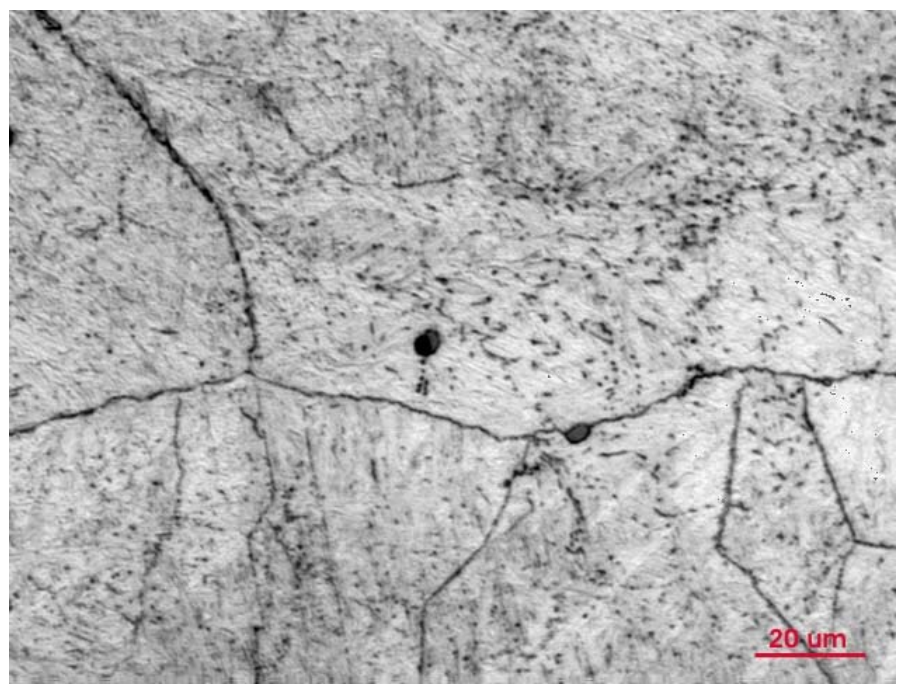

(b)

Figura 25 - Microestrutura da liga AM: (a) bruta de fundição e (b) pré-tratada a $1250^{\circ} \mathrm{C}-2 \mathrm{~h}$. Ataque: Villela.

Após a realização de experimentos preliminares entre 1000 e $1050{ }^{\circ} \mathrm{C}$, selecionou-se a temperatura de $1000^{\circ} \mathrm{C}$ para austenitização por um tempo de 50 minutos (minimização de austenita retida) e resfriamento com ar forçado.

Uma vez definido o ciclo de têmpera, amostras de todas as ligas foram duplamente revenidas a temperaturas entre $350^{\circ} \mathrm{C}$ e $600^{\circ} \mathrm{C}$ por tempos entre 1 e 4 horas para cada temperatura. Essas amostras foram submetidas a ensaio de 
microdureza Vickers realizado em microdurômetro da marca Büehler com carga de 50g. A carga de 50g foi selecionada de modo a permitir que as impressões não ultrapassassem a região da matriz nas ligas V8 e M5, que possuem as maiores frações volumétricas de carbonetos eutéticos e, conseqüentemente, as menores proporções de matriz livre. A medição das impressões foi efetuada com aumento de $1000 X$.

A figura 26 mostra um exemplo dos resultados obtidos.

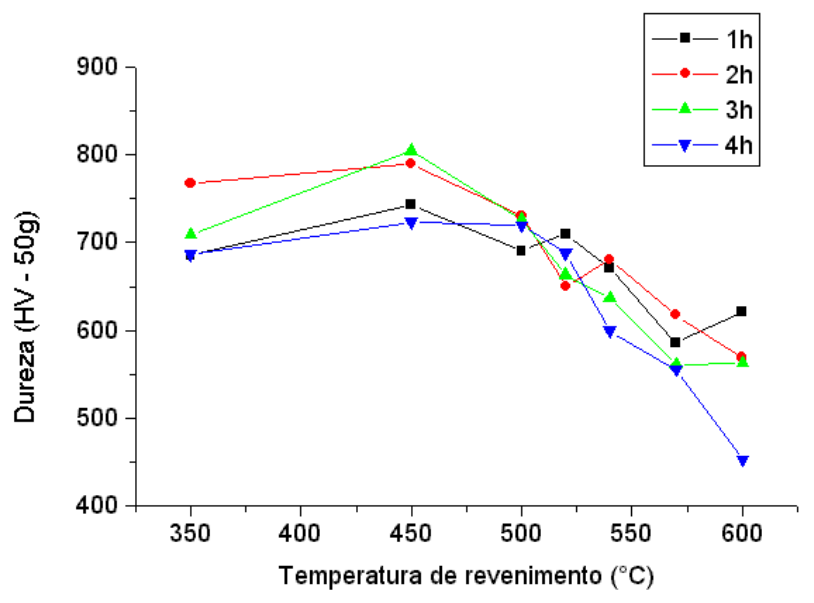

Figura 26 - Microdureza da matriz em função da temperatura de revenimento da liga V5.

Com base nas curvas de revenimento obtidas, selecionaram-se diferentes ciclos de revenimento específicos para cada liga, visando obter dois níveis de dureza da matriz: 450-500 HV e 650-700 HV. No caso da liga V8, devido à baixa relação $\mathrm{C} / \mathrm{V}$ da sua composição química, a dureza máxima obtida ficou entre 550 e $600 \mathrm{HV}$.

A tabela 5 apresenta os ciclos de revenimento selecionados para cada uma das ligas. 
Tabela 5 - Ciclos de revenimento aplicados e respectivos valores de dureza objetivados para cada liga

\begin{tabular}{|c|c|c|c|}
\hline \multirow{2}{*}{ Liga } & \multicolumn{2}{|c|}{ Ciclo de revenimento } & Dureza objetivada \\
\cline { 2 - 4 } & Temperatura $\left({ }^{\circ} \mathrm{C}\right)$ & Tempo (horas) & \\
\hline & 600 & 5 & 450 \\
\hline V5 & 540 & 1 & 650 \\
\cline { 2 - 4 } & 600 & 5 & 450 \\
\hline V6,5 & 540 & 1 & 650 \\
\cline { 2 - 4 } & 500 & 3,5 & 450 \\
\hline V8 & 600 & 2 & 650 \\
\cline { 2 - 4 } & 550 & 3 & 450 \\
\hline M2 & 600 & 3 & 550 \\
\hline M3,5 & 600 & 3 & 450 \\
\hline M5 & 600 & 3,5 & 450 \\
\hline
\end{tabular}

Todos os tratamentos foram efetuados em forno tubular com atmosfera de argônio, com exceção do ciclo de revenimento.

\section{d) Usinagem de acabamento}

Após o revenimento, os corpos-de-prova foram usinados por retífica até as dimensões finais especificadas (figura 20) com rugosidade da "pista" especificada em $0,1 \leq \mathrm{Ra} \leq 0,3$.

\section{e) Ensaios de controle}

Os corpos-de-prova foram submetidos a ensaio de líquido penetrante para detectar possíveis trincas provenientes da retificação. Constatada a ausência dessas 
trincas, mediu-se a rugosidade da "pista" em quatro pontos eqüidistantes entre si com rugosímetro compacto Surfcorder multi-função.

\section{f) Condicionamento final}

Uma vez obedecida a faixa pré-estabelecida de rugosidade, os corpos-deprova foram pintados com tinta preta resistente a temperaturas de até $650^{\circ} \mathrm{C}$, a fim de permitir a leitura da temperatura de aquecimento por meio de pirômetro de radiação calibrado para uma emissividade igual a 0,97. Esse procedimento garantiu que todos os corpos-de-prova estivessem sob a mesma condição para a leitura de temperatura.

\section{g) Nomenclatura dos corpos-de-prova}

Para facilitar a descrição e discussão dos resultados, estabeleceu-se uma nomenclatura dos corpos-de-prova associada à liga, à dureza nominal da matriz e ao número de ciclos a que foi submetido. Por exemplo: o corpo-de-prova V5/450/100 refere-se à liga V5 com dureza nominal da matriz de $450 \mathrm{HV}$ e ensaiado a 100 ciclos; o corpo-de-prova M3,5/450/500 refere-se à liga M3,5 com dureza nominal da matriz de 450 HV e ensaiado a 500 ciclos.

\subsection{Caracterização dos corpos-de-prova no estado inicial}

Destinou-se um corpo-de-prova de cada liga para a caracterização da microestrutura e da microdureza da matriz no estado inicial (antes do ensaio de fadiga térmica).

\section{a) Microestrutura}

A microestrutura foi caracterizada por meio de microscopias óptica e eletrônica de varredura (caracterização qualitativa) e analisador de imagens (caracterização quantitativa).

Para a caracterização em microscópio óptico, os corpos-de-prova foram preparados por técnicas metalográficas convencionais e submetidos aos ataques descritos na tabela 6. Para a caracterização em microscopia eletrônica de varredura, utilizou-se um reagente para ataque seletivo e profundo da matriz, possibilitando a observação dos carbonetos eutéticos em três dimensões. $\mathrm{O}$ reagente, constituído de $100 \mathrm{ml} \mathrm{H} \mathrm{H}_{2} \mathrm{O}_{2}$ e $5 \mathrm{ml} \mathrm{HF}$, é aplicado por imersão durante dez segundos, seguindo-se 
lavagens em água e álcool. A aplicação do reagente e a lavagem em álcool foram assistidas por ultrassom.

A caracterização quantitativa visou medir a fração volumétrica, o tamanho e forma dos carbonetos eutéticos, a distância livre média entre eles e a continuidade da rede de carbonetos. A medição da fração volumétrica foi realizada em analisador de imagens da marca Leica, utilizando aumento de $1000 \mathrm{X}$ e 50 campos para cada medição. Para essas medições utilizaram-se os ataques seletivos apresentados na tabela 6.

Tabela 6 - Reagentes e técnicas de ataque para observação e medição de fração volumétrica de carbonetos eutéticos em microscópio óptico

\begin{tabular}{|c|c|c|c|}
\hline Reagente & Técnica de ataque & $\begin{array}{c}\text { Carbonetos } \\
\text { revelados }\end{array}$ & Características \\
\hline $\begin{array}{c}\text { Solução aquosa } \\
\text { CrO3 }(10 \%)\end{array}$ & $\begin{array}{c}\text { Eletrolítico } \\
\text { Temperatura } \\
\text { ambiente }\end{array}$ & $\begin{array}{c}\mathrm{MC} \\
\mathrm{M}_{2} \mathrm{C}\end{array}$ & $\begin{array}{c}\text { Carbonetos com } \\
\text { coloração preta }\end{array}$ \\
\hline $10 \mathrm{~g} \mathrm{KOH}$ & $\begin{array}{c}\text { Imersão } \\
\text { Temperatura } \\
\text { ambiente }\end{array}$ & $\mathrm{M}_{2} \mathrm{C}$ & Com coloração preta \\
$100 \mathrm{~g}$ ml água $(\mathrm{CN}) 6$ & $5 \mathrm{~s}$ & & \\
\hline
\end{tabular}

As medições de fração volumétrica de carbonetos eutéticos foram realizadas em duas etapas: (i) fração volumétrica total de carbonetos eutéticos, (ii) fração volumétrica de carbonetos eutéticos $\mathrm{M}_{2} \mathrm{C}$. A fração volumétrica de carbonetos eutéticos MC foi obtida a partir da diferença entre a fração total de carbonetos e a fração de carbonetos $\mathrm{M}_{2} \mathrm{C}$.

$\mathrm{O}$ carboneto eutético $\mathrm{MC}$ foi caracterizado quanto à morfologia e ao tamanho por meio dos parâmetros diâmetro equivalente $(\phi \mathrm{eq})$ e fator de forma $(\mathrm{F}=1$ para o círculo), cujos conceitos são expressos abaixo.

$$
F \propto \frac{C}{L}
$$




$$
\phi_{e q} \propto S
$$

onde $\mathrm{C}$ é o comprimento, $\mathrm{L}$ é a largura e $\mathrm{S}$ é a área do carboneto.

As medições foram realizadas em analisador de imagem da marca Leica, utilizando aumento de 500X e 15 campos de medição.

A distribuição dos carbonetos eutéticos foi caracterizada por meio dos parâmetros continuidade (C) e distância livre média (Dm). A continuidade foi determinada por meio de uma função do analisador de imagem denominada "esqueleto"; esta função é tal que, quanto mais contínua a rede de carbonetos eutéticos, maior o valor de C. As medições foram realizadas em analisador de imagem da marca Leica, utilizando aumento de 250X e 30 campos de medição.

Os valores de distância livre média entre carbonetos $(\mathrm{Dm})$ foram obtidos pelo método dos interceptos em microscópio óptico com ocular graduada em forma circular para minimizar os efeitos de direcionalidade da microestrutura, utilizando aumento de 250X e 15 campos de medições.

\section{b) Microdureza da matriz}

A medição da microdureza da matriz foi realizada por meio dos mesmos procedimentos adotados durante a obtenção das curvas de revenimento das ligas, ou seja, em cada corpo-de-prova foram realizadas 5 medições com carga de $50 \mathrm{~g}$ e aumento de 1000X em microdurômetro da marca Büehler.

\subsection{Ensaio de fadiga térmica}

A figura 27 mostra uma visão geral da máquina de fadiga térmica e a figura 28 mostra um detalhe da bobina de aquecimento do corpo-de-prova. 


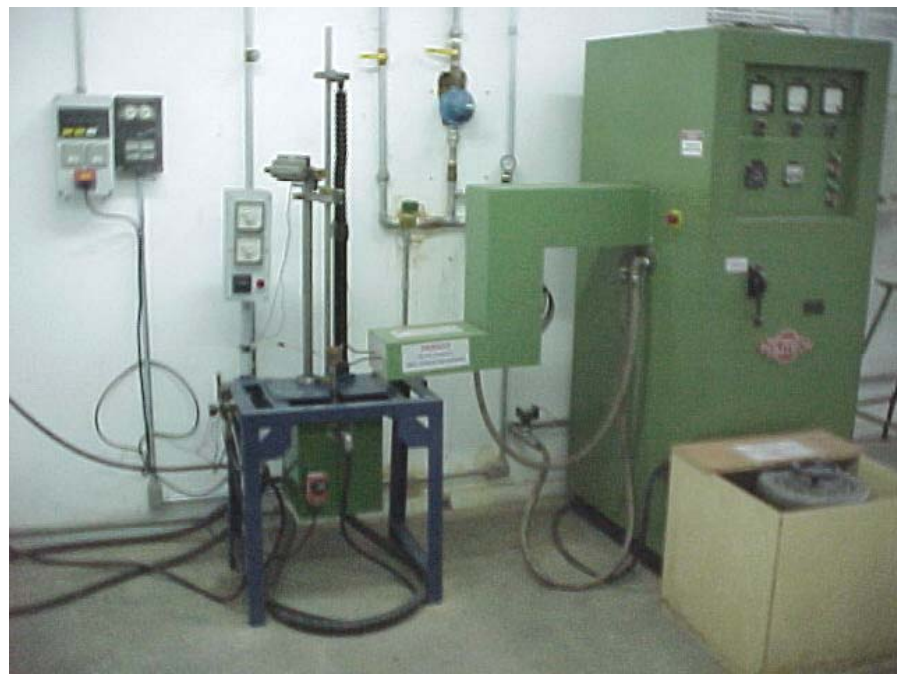

Figura 27 - Vista geral da máquina de fadiga térmica.

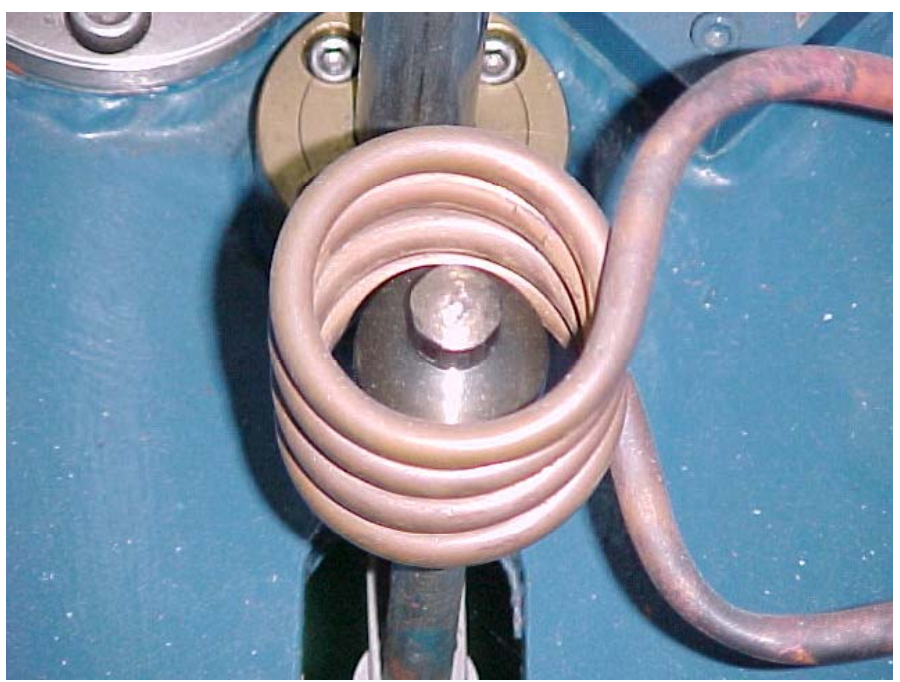

Figura 28 - Detalhe do corpo-de-prova no interior da bobina de indução (aquecimento).

Os corpos-de-prova foram ensaiados sob fadiga térmica a 100 e a 500 ciclos, com uma repetição para cada ensaio. No ensaio, o corpo-de-prova é transportado alternadamente do interior da bobina para o tanque de água (e vice-versa) por intermédio de sistema pneumático comandado, no aquecimento, por pirômetro de radiação e, no resfriamento, por temporizador. A quantidade de ciclos é contabilizada por meio de um contador digital localizado no final do curso ascendente do cilindro pneumático. A superfície dos corpos-de-prova foi aquecida até $600^{\circ} \mathrm{C}$ (temperatura máxima estimada na superfície de cilindros de laminação a quente de tiras de aço) 
em 10s, seguindo-se, imediatamente, a imersão em água a temperatura entre 25 e $35^{\circ} \mathrm{C}$ por 45 segundos.

O tempo de resfriamento no interior do tanque de água foi determinado a partir da necessidade de equalizar as temperaturas da superfície e do centro do corpode-prova, eliminando gradientes de temperatura remanescentes dos ciclos anteriores.

A figura 29 mostra, esquematicamente, o ciclo térmico aplicado ao corpo-deprova durante o ensaio.

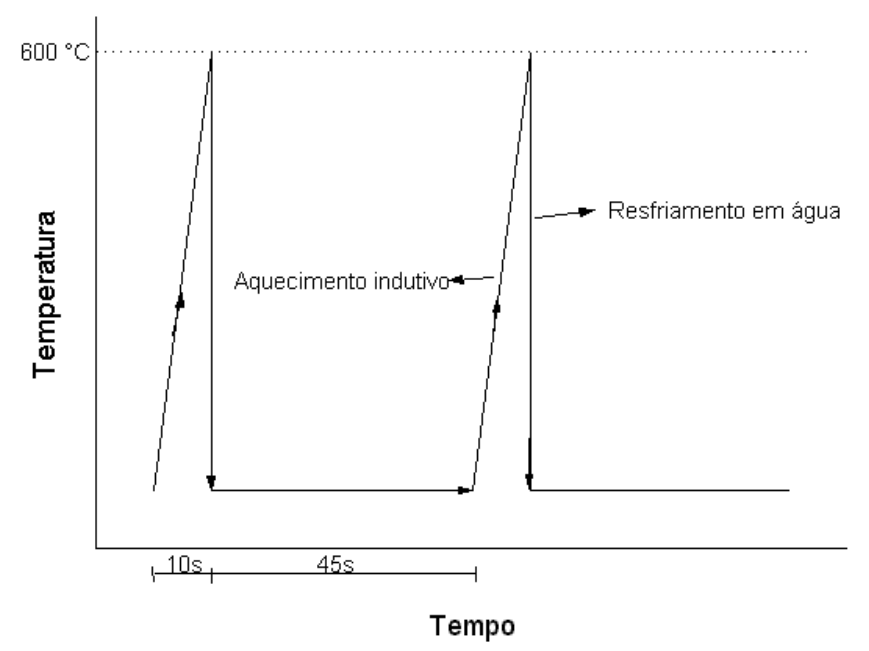

Figura 29 - Representação esquemática do ciclo térmico aplicado ao corpo-de-prova durante o ensaio de fadiga térmica.

\subsection{Caracterização dos corpos-de-prova no estado final}

A caracterização dos corpos-de-prova no estado final consistiu de ensaio de líquido penetrante, metalografia qualitativa, medição da quantidade e profundidade de trincas e ensaio de microdureza.

\section{a) Caracterização macroscópica (ensaio de líquido penetrante)}

Após os ensaios de fadiga térmica, os corpos-de-prova foram novamente submetidos a ensaio de líquido penetrante para revelar a morfologia e a intensidade das trincas macroscópicas.

\section{b) Caracterização microscópica}


Após a caracterização das trincas macroscópicas por líquido penetrante, os corpos-de-prova foram cortados em cortadeira com disco abrasivo com baixo esforço mecânico (evitar propagação das trincas de fadiga devido às tensões geradas no corte) no plano perpendicular à "pista" e eqüidistante de suas extremidades, de tal forma que as trincas radiais ficaram visíveis neste plano. A figura 30 mostra uma representação do plano de corte e da seção visível após o corte.

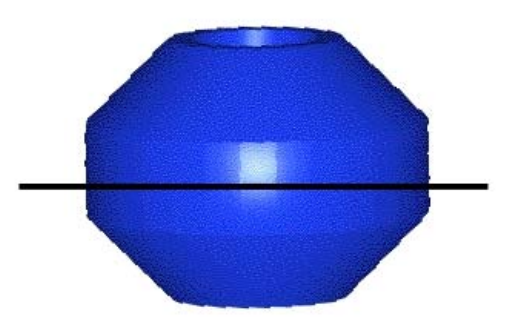

(a)

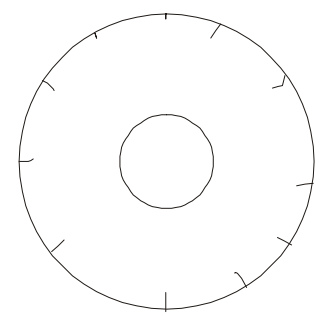

(b)

Figura 30 - Representação esquemática do plano de corte (a) e da seção transversal do corpo-de-prova visível após o corte (b).

Seguiram-se operações de embutimento em baquelite condutora, lixamento de desbaste com rebolo de alumina, lixamento fino com lixas \#300 e \#600 e polimento com paste de diamante (6 a $1 \mu \mathrm{m})$ e com solução aquosa de sílica.

\section{$\underline{\text { Metalografia qualitativa }}$}

A metalografia qualitativa dos corpos-de-prova no estado final teve por objetivo identificar e caracterizar o sítio de nucleação e o caminho de propagação das trincas. Para isso foram empregadas as técnicas metalográficas já descritas no item 3.2 .

\section{Medição da quantidade de trincas}

A medição foi realizada com o emprego de microscópio óptico e aumento de 500X, com o auxílio de um contador mecânico. Para facilitar o procedimento, a amostra foi dividida em quatro quadrantes e a contagem foi realizada por quadrante, conforme mostra a figura 31. 


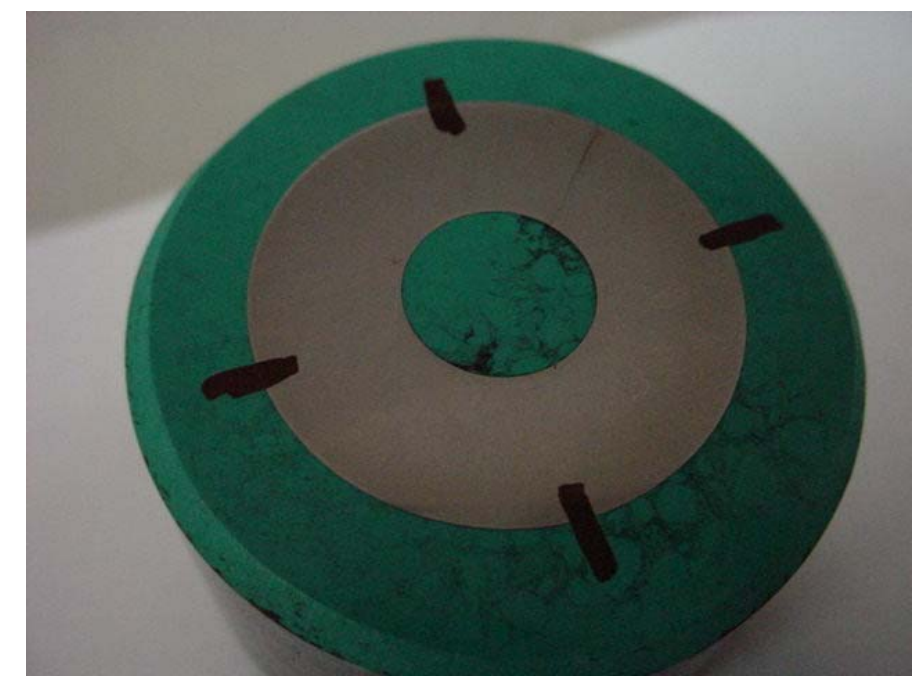

Figura 31 - Seção transversal do corpo-de-prova após o ensaio, mostrando a divisão em quadrantes para contagem da quantidade de trincas e a "trinca passante".

Alguns corpos-de-prova apresentaram uma trinca radial que se propagou por toda sua espessura e foi denominada, nesse trabalho, "trinca passante" (figura 31). Atribuiu-se a propagação dessa trinca ao aquecimento heterogêneo ao longo da circunferência do corpo-de-prova decorrente da configuração da bobina de aquecimento, conforme mostra, esquematicamente, a figura 32. A região à frente da espira mostrada na figura $32 \mathrm{~b}$ aquece com mais intensidade do que as demais.

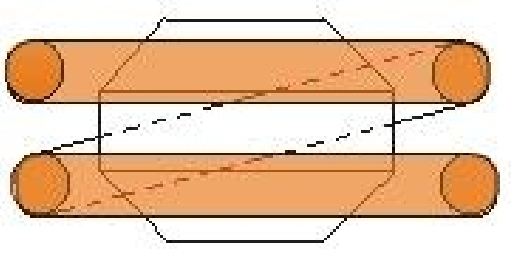

(a)

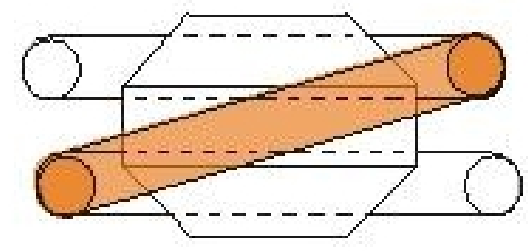

(b)

Figura 32 - Representação esquemática do posicionamento do corpo-de-prova na bobina de aquecimento da máquina de fadiga térmica, mostrando (a) pista na região da mira do pirômetro óptico e (b) pista na região diametralmente oposta .

Nos corpos-de-prova com trinca passante, observou-se que o número de trincas na região ao seu redor era significativamente inferior ao do restante do perímetro (provavelmente devido ao alívio de tensões local provocado pela presença 
da trinca passante); nos corpos-de-prova sem trinca passante, a região exposta à maior temperatura pode ser identificada por apresentar um número de trincas significativamente superior ao das demais regiões e uma camada de óxido mais espessa.

Para evitar que estes fatores exercessem influência sobre os resultados das medições, não foram contabilizadas as trincas no quadrante contendo as heterogeneidades mencionadas.

Na apresentação dos resultados, utilizou-se o parâmetro densidade de trincas (Dt), calculado pela expressão:

$$
D t=\frac{N t}{\frac{3}{4}(\pi * d)}
$$

onde $N t$ é o número de trincas e $d$ é o diâmetro do corpo-de-prova.

Medição da profundidade máxima de trinca (Pmáx)

A medição da profundidade máxima das trincas foi realizada em microscópio óptico dotado de ocular graduada com aumento variando entre 100 e 500X. Observou-se, em alguns corpos-de-prova, a presença de trincas cujas nucleação e propagação foram induzidas por microrrechupes internos que atuaram como concentradores de tensão (figuras 33 a 35). Estas trincas não foram consideradas nas medições da profundidade máxima. Para efeito de apresentação e discussão dos resultados, utilizou-se o parâmetro taxa de propagação (da/dN), calculado pela expressão

$$
d a / d N=\frac{P m a ́ x}{N c}
$$

onde Pmáx é a profundidade máxima de trinca e $N c$ é o número de ciclos. 


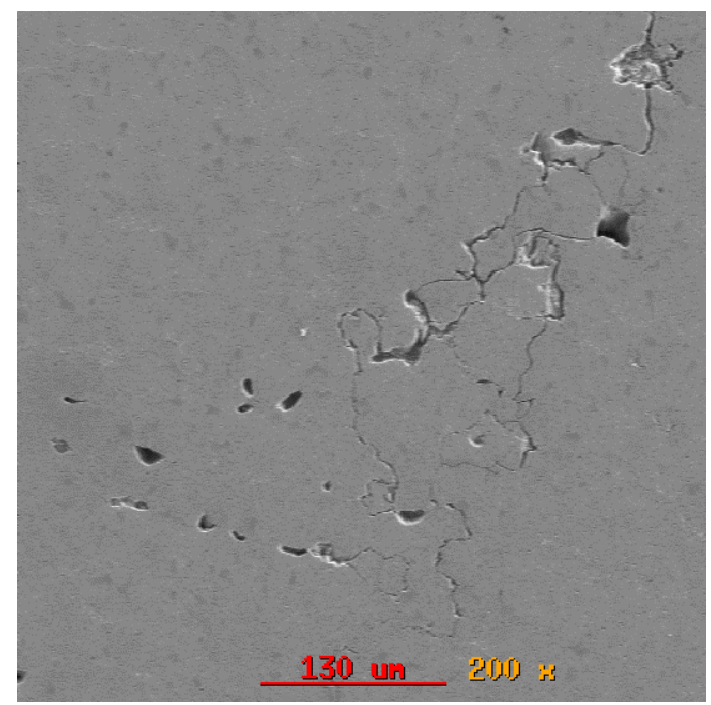

Figura 33 - Seção transversal do corpo-de-prova V5/450/100 com $30 \mathrm{~mm}$ de diâmetro, em que se observa a propagação de trinca associada a microrrechupe. $\mathrm{MEV}$ - elétrons secundários.

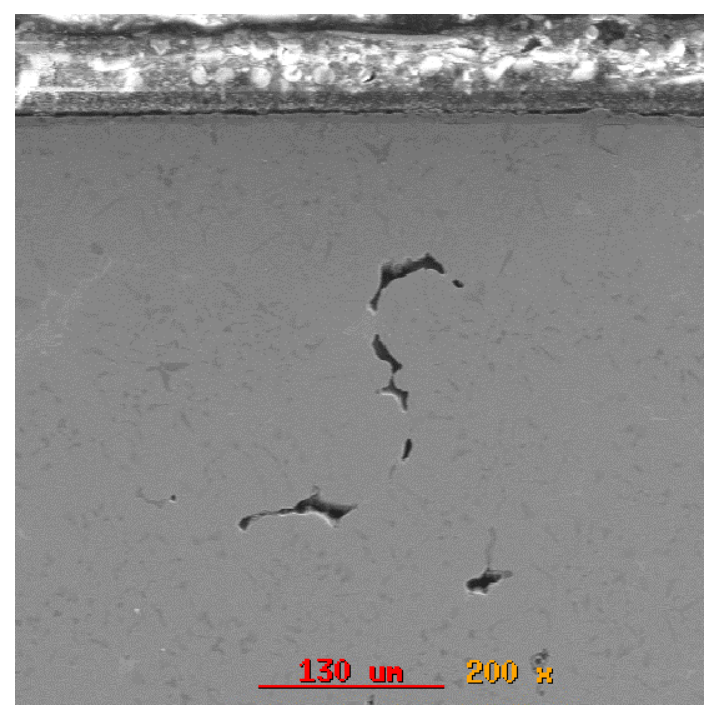

Figura 34 - Seção transversal do corpo-de-prova V6,5/450/500, em que se observa uma concentração de microrrechupes abaixo da sua superfície. MEV - elétrons secundários 


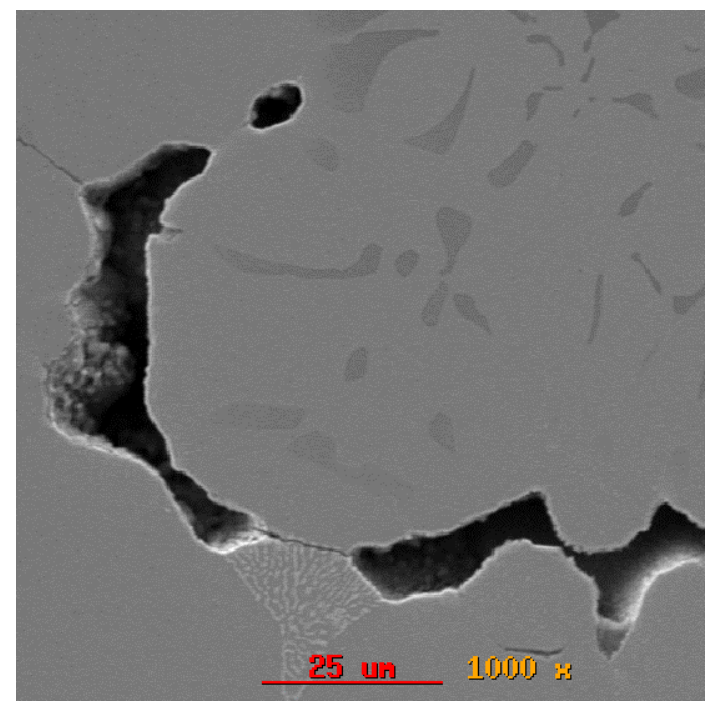

Figura 35 - Detalhe da figura 34, mostrando a formação de trinca associada a microrrechupe. MEV - elétrons secundários.

\section{c) Microdureza da matriz}

As medições foram realizadas em microdurômetro da marca Buhler, com carga de 50g, a 100, 200 e $300 \mu \mathrm{m}$ de distância da superfície externa dos corpos-deprova, ao longo da sua circunferência (excluindo o quadrante contendo a trinca passante). Foram realizadas cinco medições em cada corpo-de-prova. 


\section{RESULTADOS}

\subsection{Primeira série de experimentos}

Os resultados da primeira série de experimentos foram divididos em duas partes: caracterização dos corpos-de-prova no estado inicial e caracterização dos corpos-de-prova no estado final.

\subsubsection{Caracterização dos corpos-de-prova no estado inicial}

\section{a) Microestrutura}

\section{Caracterização qualitativa}

A liga AM, sem carbonetos eutéticos, possui uma microestrutura constituída de martensita revenida e carbonetos secundários com tamanho máximo de $1 \mu \mathrm{m}$ (figuras 36 e 37).

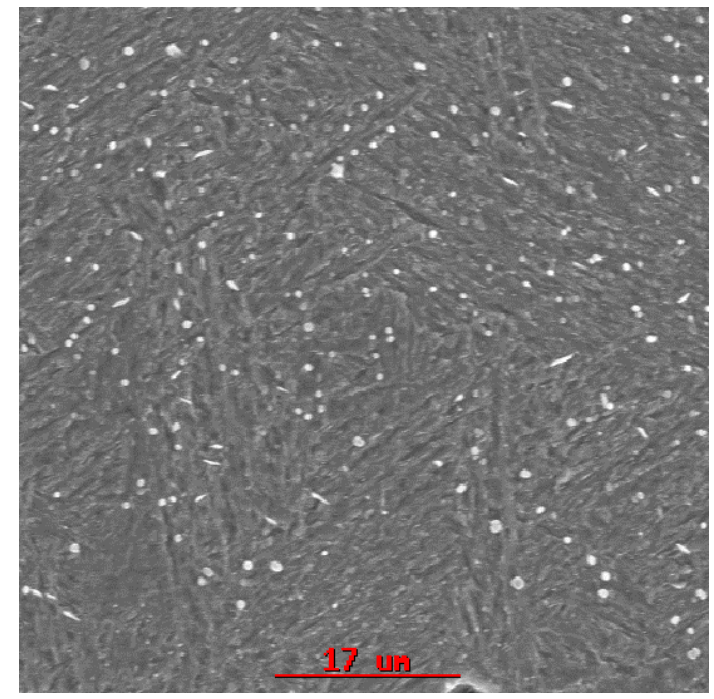

Figura 36 - Microestrutura da liga AM, mostrando a matriz de martensita revenida e os carbonetos secundários. MEV - elétrons secundários. 


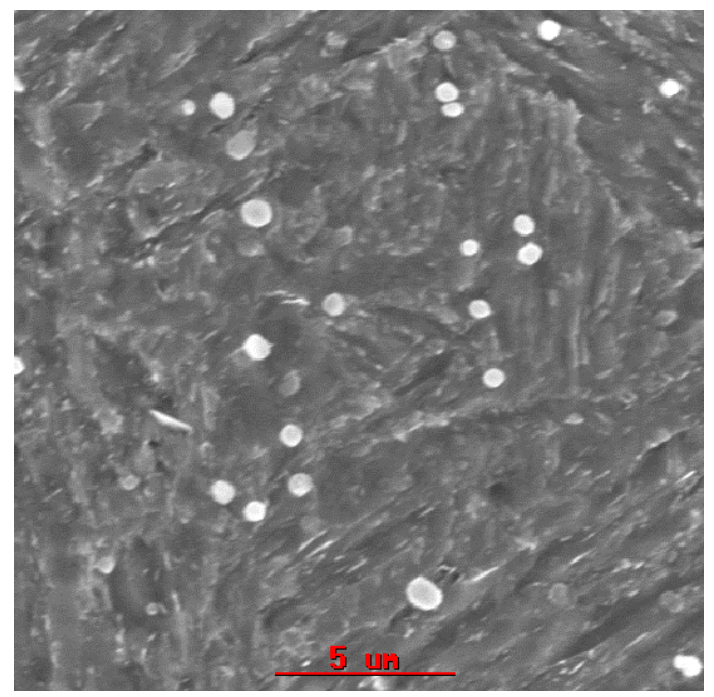

Figura 37 - Microestrutura da liga AM. Detalhe da figura 36. MEV - elétrons secundários.

Com exceção da liga AM, todas as ligas apresentaram carbonetos eutéticos do tipo $\mathrm{MC}$ e $\mathrm{M}_{2} \mathrm{C}$. A liga V5, hipoeutética, possui em sua microestrutura dendritas de martensita revenida com precipitação de carbonetos secundários e carbonetos eutéticos interdendríticos. O eutético MC possui morfologia predominantemente irregular com os carbonetos $\mathrm{MC}$ em forma de pétala e uma pequena fração de eutético com morfologia regular-complexa (formando células eutéticas), em que o carboneto MC possui a forma de pétala ramificada (este tipo de eutético é caracterizado por um elevado grau de cooperação durante seu crescimento). O eutético $\mathrm{M}_{2} \mathrm{C}$ possui morfologia regular-complexa, com o carboneto $\mathrm{M}_{2} \mathrm{C}$ na forma lamelar. A figura 38 apresenta a distribuição de carbonetos da microestrutura dessa liga, destacando os eutéticos mencionados. 


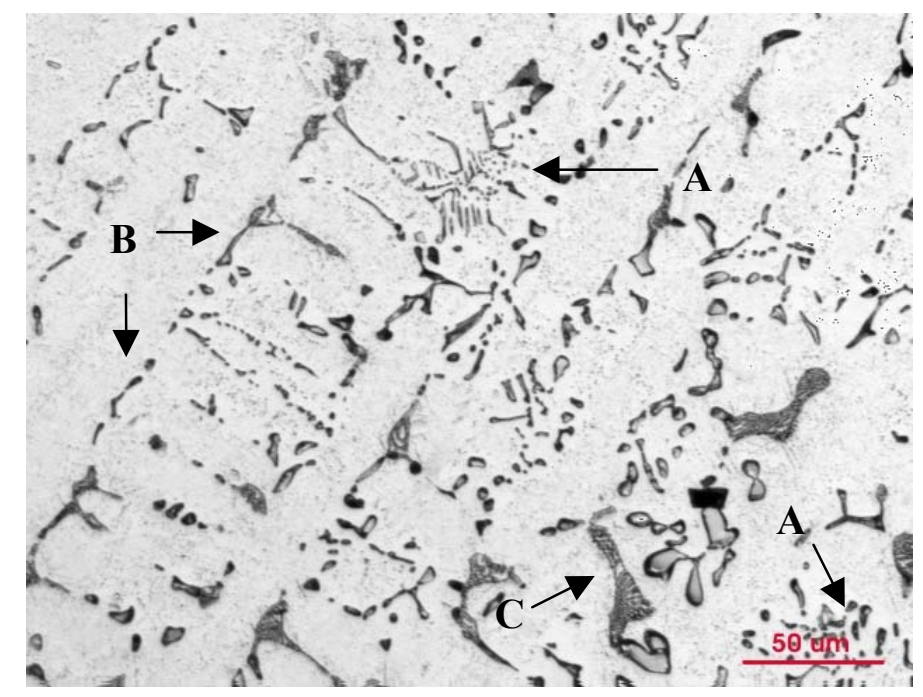

Figura 38 - Microestrutura da liga V5, mostrando a distribuição dos carbonetos eutéticos $\mathrm{MC}$ e $\mathrm{M}_{2} \mathrm{C}$ : A- $\mathrm{MC}$ regular-complexo, B- $\mathrm{MC}$ irregular e $\mathbf{C}-\mathrm{M}_{2} \mathrm{C}$ regular complexo. Ataque: Eletrolítico + Grosbeck.

A figura 39 mostra esses eutéticos em MEV, onde se pode observar com maiores detalhes a morfologia dos carbonetos.

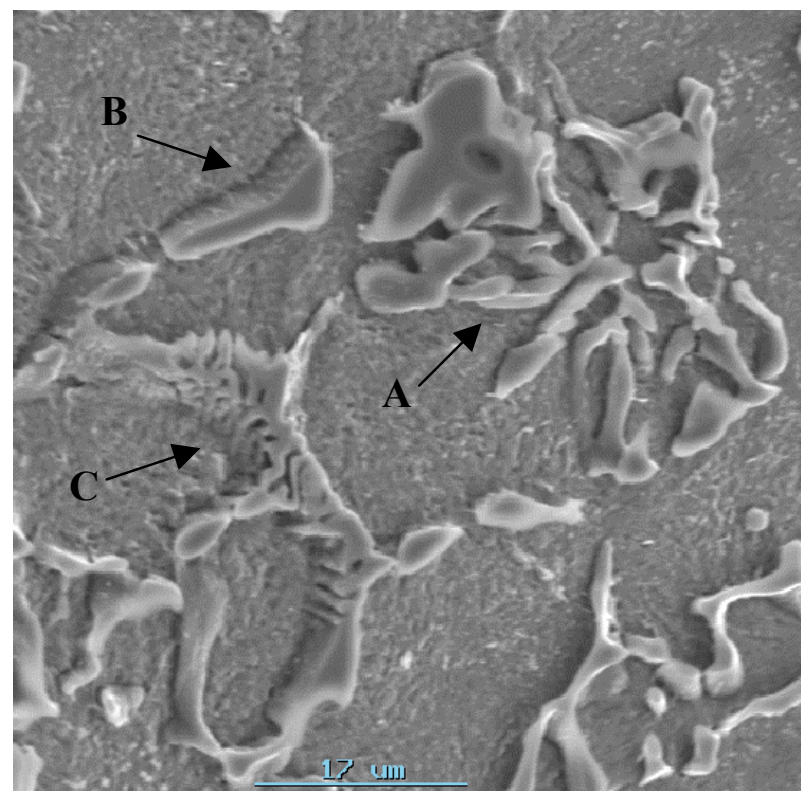

Figura 39 - Microestrutura da liga V5, mostrando detalhes dos carbonetos eutéticos $\mathrm{MC}$ e $\mathrm{M}_{2} \mathrm{C}$ : A- $\mathrm{MC}$ regular-complexo, B- $\mathrm{MC}$ irregular e $\mathbf{C}-\mathrm{M}_{2} \mathrm{C}$ regular complexo. MEV - elétrons secundários. 
A liga V6,5 possui maior quantidade de carbonetos eutéticos do que a liga V5 e, conseqüentemente, menor fração de dendritas. Além disso, o maior teor de vanádio dessa liga promove o aumento do grau de cooperação durante o crescimento do eutético MC, resultando uma maior fração desse eutético com morfologia regularcomplexa, embora ainda esteja presente o eutético $\mathrm{MC}$ irregular. $\mathrm{O}$ eutético $\mathrm{M}_{2} \mathrm{C}$ é semelhante ao da liga V5, embora esteja presente em menor quantidade. A distribuição dos carbonetos eutéticos pode ser observada na figura 40 e os detalhes da morfologia, na figura 41.

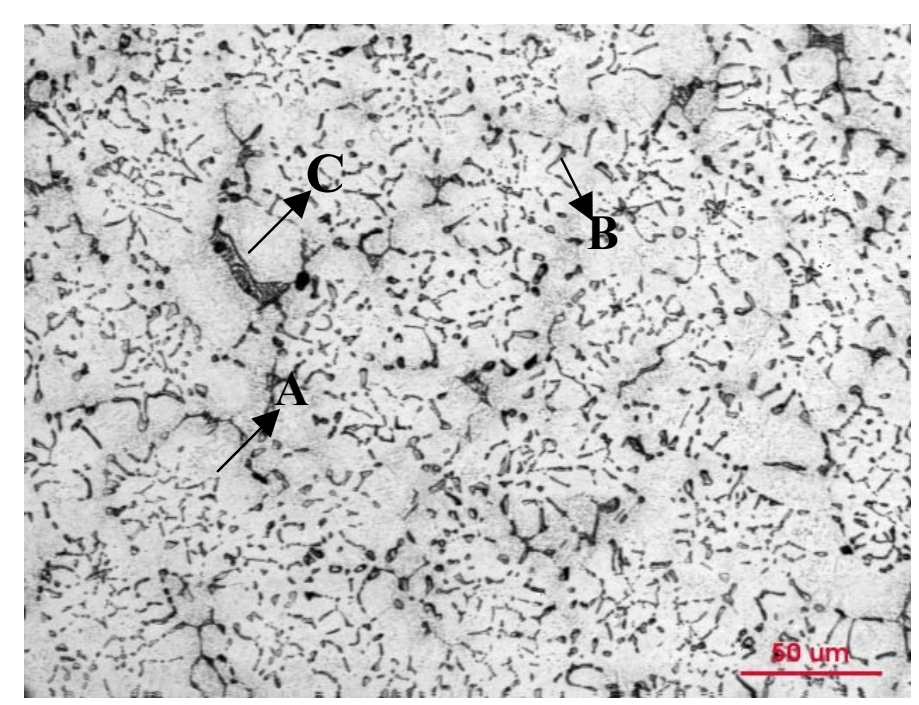

Figura 40 - Microestrutura da liga V6,5, mostrando a distribuição dos carbonetos eutéticos $\mathrm{MC}$ e $\mathrm{M}_{2} \mathrm{C}$ : A- $\mathrm{MC}$ regular-complexo, B- $\mathrm{MC}$ irregular e $\mathbf{C}-\mathrm{M}_{2} \mathrm{C}$ regular complexo. Ataque: Eletrolítico + Grosbeck. 


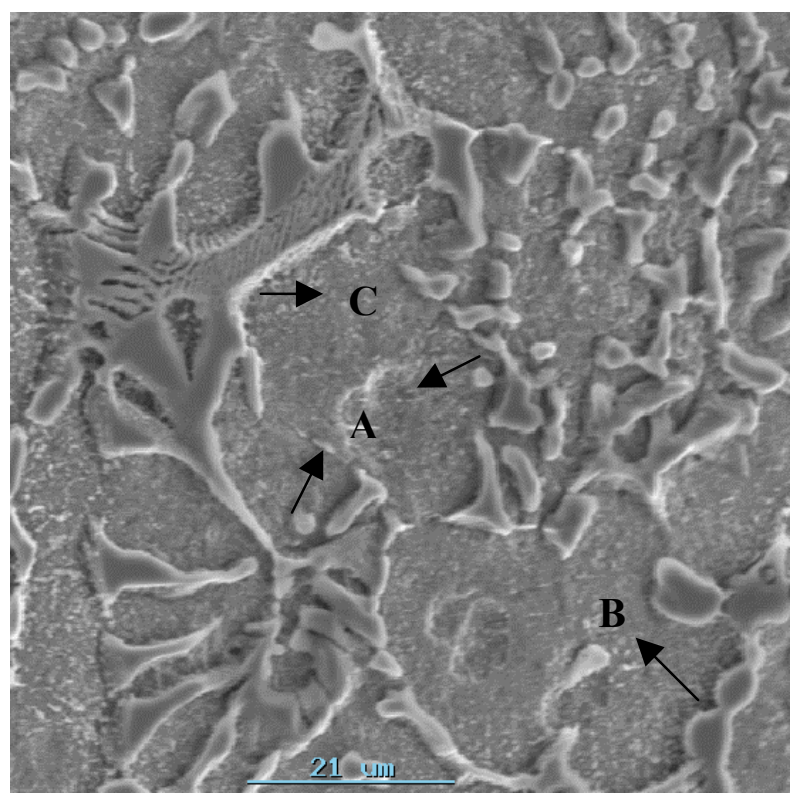

Figura 41 - Microestrutura da liga V6,5, mostrando detalhes dos carbonetos eutéticos $\mathrm{MC}$ e $\mathrm{M}_{2} \mathrm{C}$ : A- $\mathrm{MC}$ regular-complexo, B- $\mathrm{MC}$ irregular e $\mathbf{C}-\mathrm{M}_{2} \mathrm{C}$ regular complexo. $\mathrm{MEV}$ - elétrons secundários.

Na liga V8 houve uma alteração na morfologia predominante do eutético MC, que passou a ser uma mistura de eutético divorciado, em que os carbonetos $\mathrm{MC}$ são constituídos de partículas idiomórficas, e eutético irregular. O eutético $\mathrm{M}_{2} \mathrm{C}$, presente em pequena quantidade, é semelhante ao das ligas V5 e V6,5. As figuras 42 e 43 mostram, respectivamente, a distribuição dos carbonetos eutéticos $\mathrm{MC}$ e $\mathrm{M}_{2} \mathrm{C}$ na liga V8 e suas características morfológicas. 


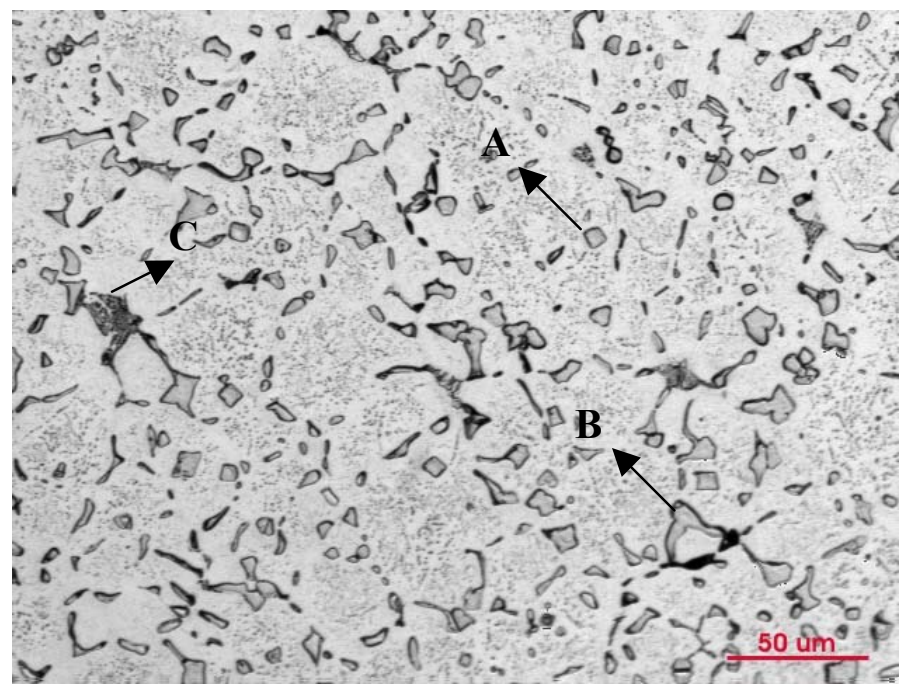

Figura 42 - Microestrutura da liga V8, mostrando a distribuição dos carbonetos eutéticos $\mathrm{MC}$ e $\mathrm{M}_{2} \mathrm{C}$ : A- $\mathrm{MC}$ divorciado, B- $\mathrm{MC}$ irregular e C- $\mathrm{M}_{2} \mathrm{C}$ regular complexo. Ataque: Eletrolítico + Grosbeck.

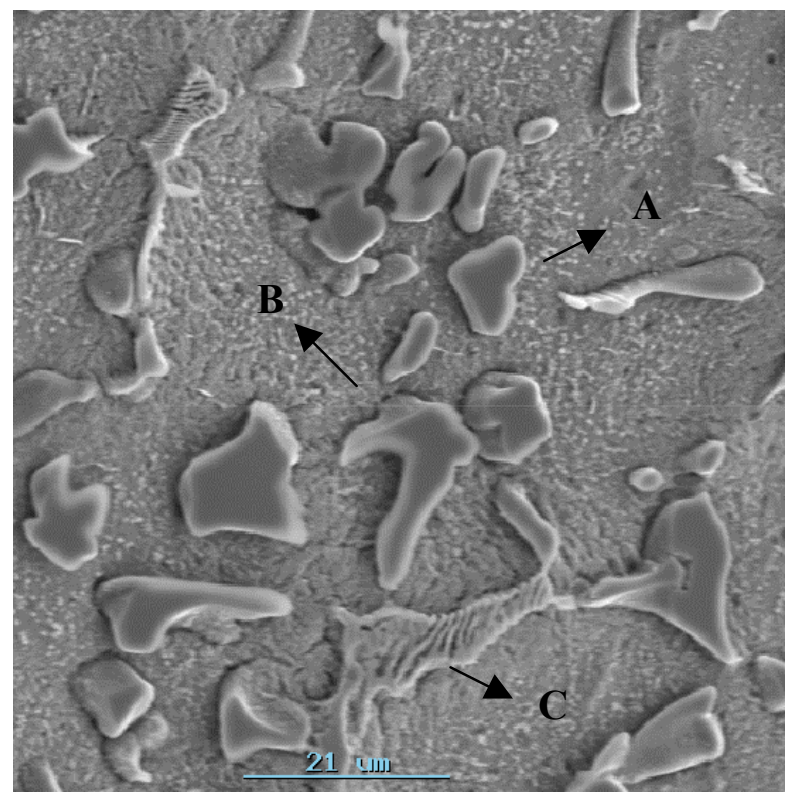

Figura 43 - Microestrutura da liga V8, mostrando detalhes dos carbonetos eutéticos $\mathrm{MC}$ e $\mathrm{M}_{2} \mathrm{C}$ : A- $\mathrm{MC}$ divorciado, B- $\mathrm{MC}$ irregular e $\mathbf{C}-\mathrm{M}_{2} \mathrm{C}$ regular complexo. $\mathrm{MEV}-$ elétrons secundários.

A matriz dessas ligas é composta de martensita revenida e carbonetos secundários com tamanho máximo de $0,5 \mu \mathrm{m}$ (figuras 44 e 45 ). 


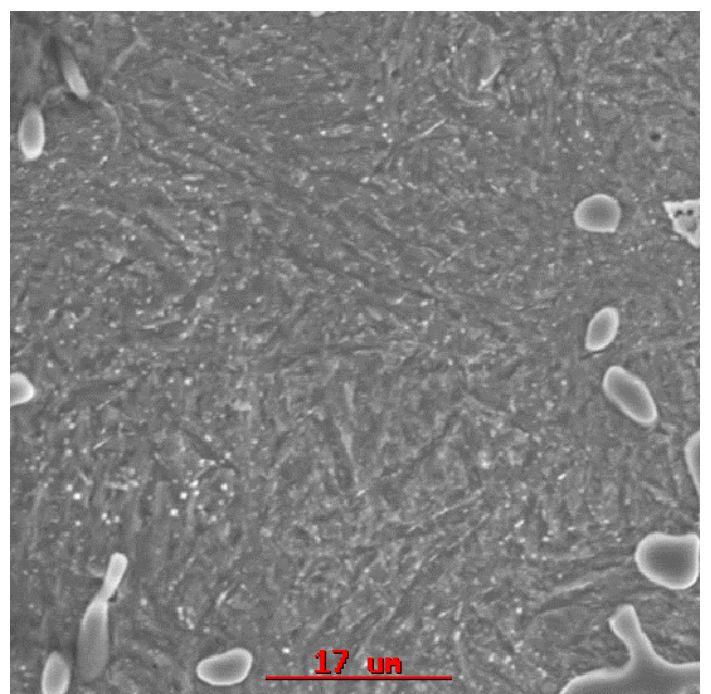

Figura 44 - Matriz da liga V5, mostrando a martensita revenida e os carbonetos secundários. MEV - elétrons secundários.

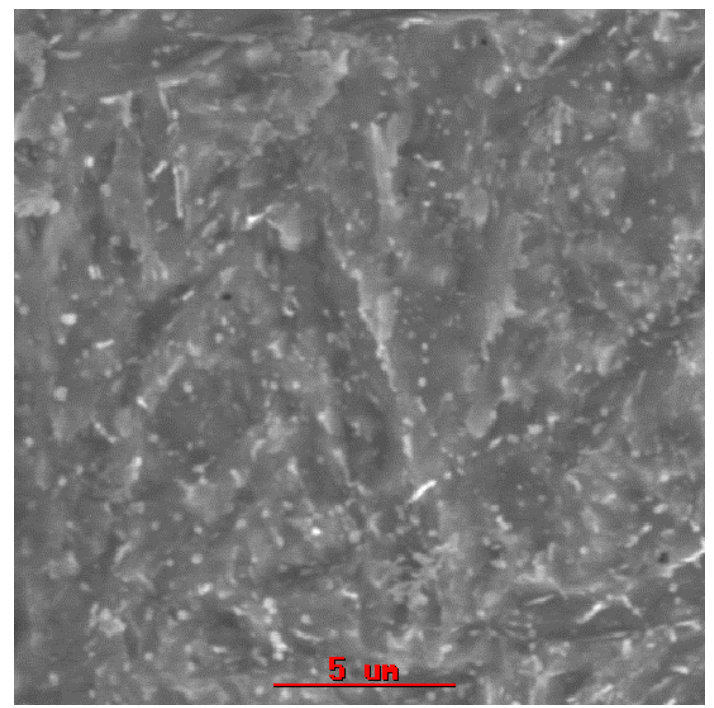

Figura 45 - Detalhe da figura 44. MEV - elétrons secundários.

A figura 46 mostra a evolução da distribuição dos carbonetos eutéticos com o aumento do teor de vanádio para as ligas da primeira série de experimentos. 


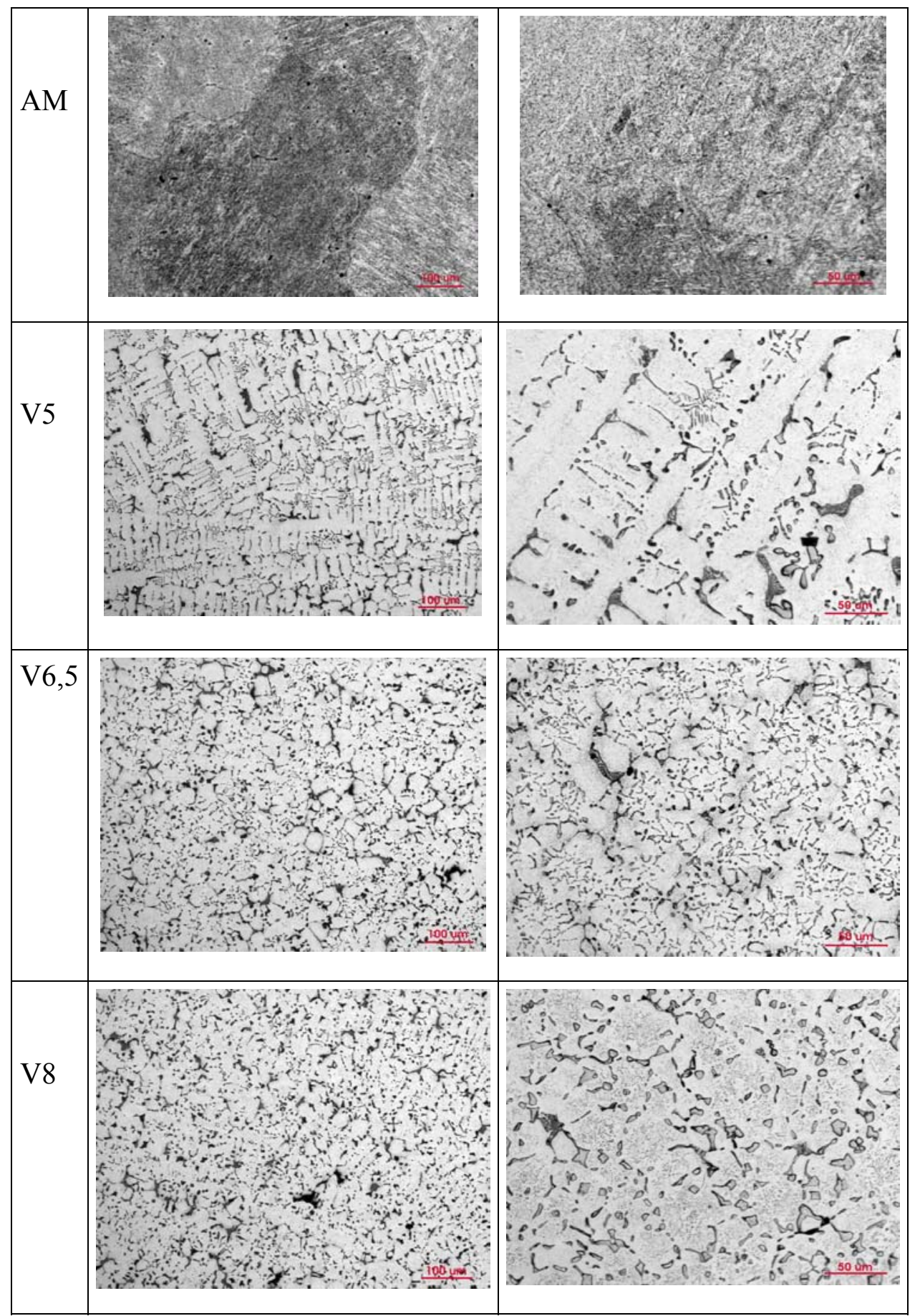

Figura 46 - Evolução da distribuição dos carbonetos eutéticos das ligas da primeira série de experimentos. 


\section{Caracterização quantitativa}

A tabela 7 apresenta os valores médios de fração volumétrica dos carbonetos eutéticos das ligas da primeira série de experimentos e respectivos intervalos de variação. Os intervalos de variação foram determinados para um nível de confiança de $95 \%$.

Tabela 7 - Fração volumétrica de carbonetos eutéticos das ligas da primeira série de experiências

\begin{tabular}{|c|c|c|c|}
\hline \multirow{2}{*}{ Liga } & \multicolumn{2}{|c|}{ Fração volumétrica de carbonetos eutéticos } \\
\cline { 2 - 4 } & Total & MC & M2C \\
\hline V5 & $0,090 \pm 0,004$ & $0,065 \pm 0,007$ & $0,025 \pm 0,006$ \\
\hline V6,5 & $0,119 \pm 0,004$ & $0,105 \pm 0,005$ & $0,014 \pm 0,003$ \\
\hline V8 & $0,137 \pm 0,003$ & $0,129 \pm 0,003$ & $0,008 \pm 0,002$ \\
\hline
\end{tabular}

Os resultados da tabela mostram que o aumento do teor de vanádio promove:

i) Aumento da fração volumétrica de carbonetos eutéticos total;

ii) Aumento da fração volumétrica de carbonetos eutéticos $\mathrm{MC}$;

iii) Diminuição da fração volumétrica de carbonetos eutéticos $\mathrm{M}_{2} \mathrm{C}$.

A tabela 8 apresenta os valores médios do fator de forma (F) e do diâmetro equivalente $\left(\phi_{\mathrm{eq}}\right)$ do carboneto eutético $\mathrm{MC}$, bem como os da distância livre média $\left(D_{m}\right)$ entre eles e da continuidade $(C)$ da rede de carbonetos. Os intervalos de variação foram determinados para um nível de confiança de 95\%. 
Tabela 8 - Fator de forma, diâmetro equivalente, distância livre média e continuidade do carboneto eutético MC das ligas da primeira série de experimentos

\begin{tabular}{|c|c|c|c|c|}
\hline Liga & $F$ & $\phi_{\text {eq }}(\mu \mathrm{m})$ & $C\left(\mu \mathrm{m}^{2}\right)$ & $D_{\mathrm{m}}(\mu \mathrm{m})$ \\
\hline V5 & $2,35 \pm 0,04$ & $3,77 \pm 0,07$ & $36,0 \pm 1,33$ & $33,7 \pm 3,59$ \\
\hline V6,5 & $2,24 \pm 0,03$ & $3,52 \pm 0,06$ & $31,7 \pm 1,12$ & $26,6 \pm 2,14$ \\
\hline V8 & $2,00 \pm 0,02$ & $6,79 \pm 0,08$ & $25,6 \pm 0,43$ & $29,8 \pm 2,43$ \\
\hline
\end{tabular}

A figura 47 apresenta a variação dos valores médios do fator de forma e do diâmetro equivalente do carboneto eutético $\mathrm{MC}$ em função da sua fração volumétrica.

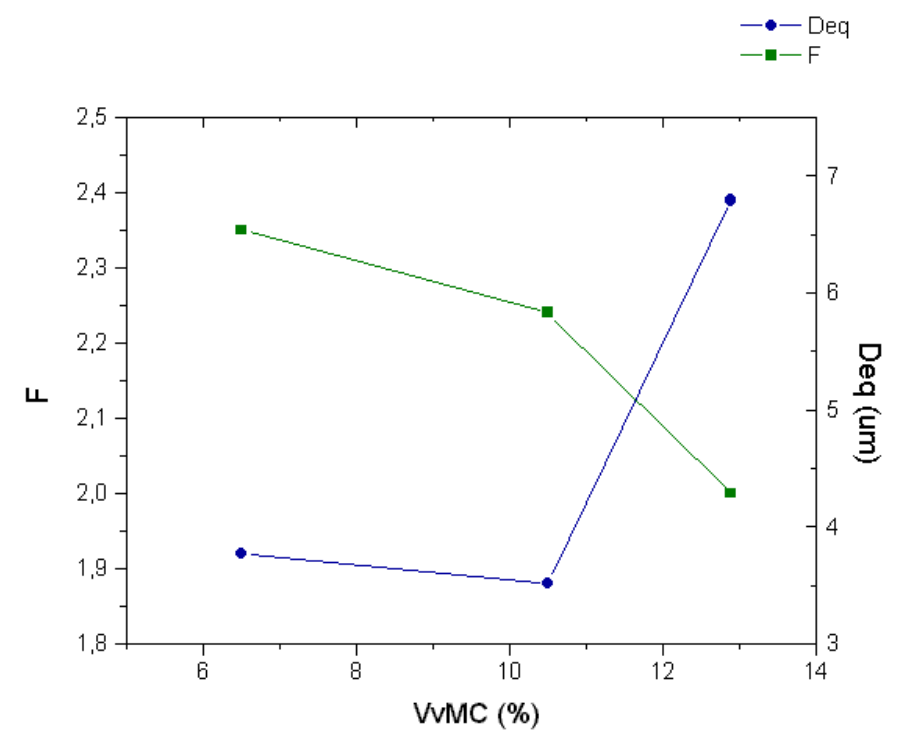

Figura 47 - Diâmetro equivalente e fator de forma do carboneto eutético MC em função da sua fração volumétrica.

Observa-se que o fator de forma do carboneto eutético MC diminui com o aumento da sua fração volumétrica e que o diâmetro equivalente apresenta um mínimo para a liga com 10,5\% de carboneto eutético MC (liga V6,5).

A figura 48 apresenta a variação dos valores médios da distância livre média e continuidade dos carbonetos eutéticos $\mathrm{MC}$ em função da sua fração volumétrica. 


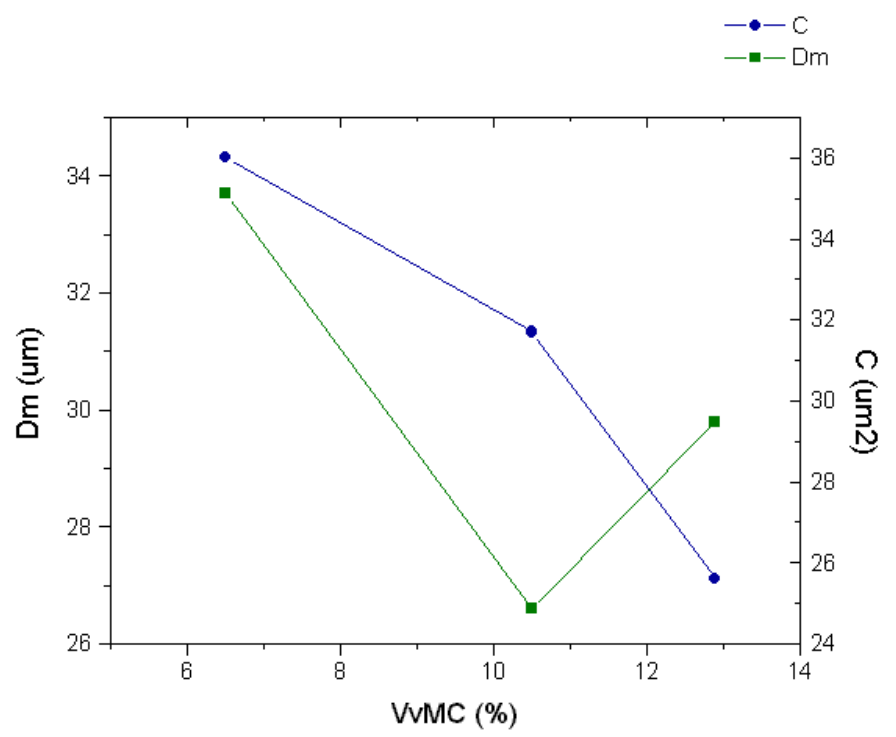

Figura 48 - Distância livre média e continuidade entre carbonetos eutéticos em função da fração volumétrica de carboneto MC.

Observa-se que a distância livre média entre os carbonetos eutéticos apresenta um mínimo para a liga V6,5 (10,5\% de carbonetos MC) e que a continuidade de carbonetos diminui da liga V5 para a liga V8.

\section{b) Microdureza da matriz}

A tabela 9 apresenta os valores médios de microdureza da matriz dos corposde-prova e os respectivos intervalos de variação determinados para um nível de confiança de $95 \%$. 
Tabela 9 -Valores médios de microdureza da matriz dos corpos-de-prova da primeira série de experiências

\begin{tabular}{|c|c|}
\hline Liga & $\begin{array}{c}\text { Dureza } \\
(\mathrm{HV}-50 \mathrm{~g})\end{array}$ \\
\hline \multirow{2}{*}{ AM } & $450 \pm 9,30$ \\
\cline { 2 - 3 } & $635 \pm 5,60$ \\
\hline \multirow{2}{*}{ V5 } & $479 \pm 8,20$ \\
\cline { 2 - 3 } & $657 \pm 36,6$ \\
\hline \multirow{2}{*}{ V6,5 } & $485 \pm 26,7$ \\
\cline { 2 - 2 } & $680 \pm 37,8$ \\
\hline \multirow{2}{*}{ V8 } & $492 \pm 31,9$ \\
\cline { 2 - 2 } & $573 \pm 18,7$ \\
\hline
\end{tabular}

\subsubsection{Caracterização dos corpos-de-prova no estado final}

\section{a) Caracterização macroscópica (ensaio de líquido penetrante)}

De uma forma geral, os resultados de caracterização macroscópica das trincas mostram dois tipos de comportamento:

i) Os corpos-de-prova da liga AM (sem carboneto eutético na microestrutura), independentemente da dureza da matriz e do número de ciclos, não apresentaram trincas macroscópicas;

ii) Os corpos-de-prova das demais ligas (com carboneto eutético na microestrutura) apresentaram trincas radial e circunferencial (figura 49), com exceção dos corpos-de-prova V5/450/100 (um corpo-deprova) e V8/450/100 (dois corpos-de-prova). 


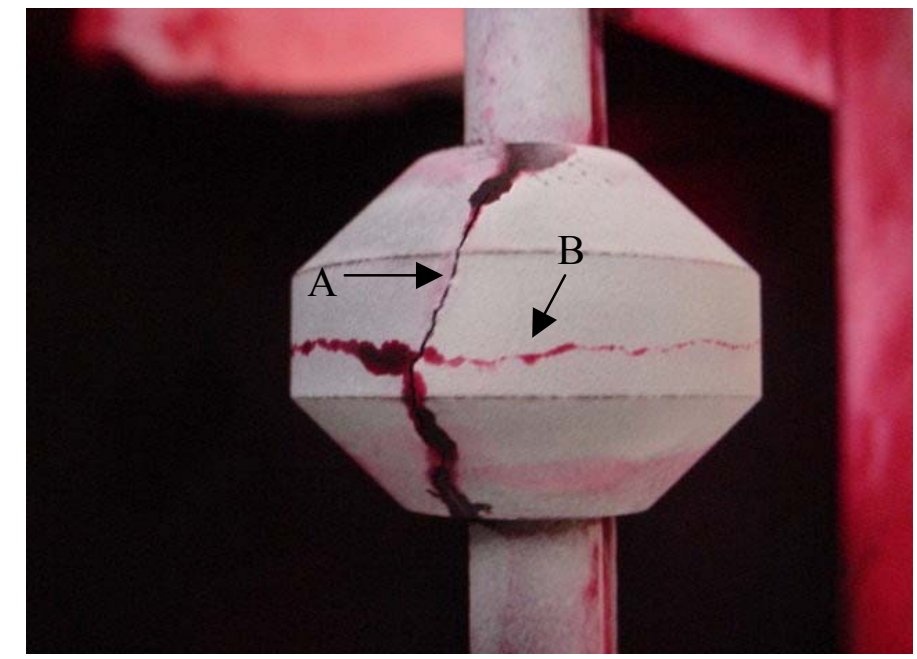

Figura 49 - Corpo-de-prova V5/650/500. A - Trinca radial e B - Trinca circunferencial.

Na maior parte dos corpos-de-prova as trincas são únicas e sem ramificação, sendo que a trinca circunferencial propaga-se preferencialmente pela pista do corpode-prova. A figura 50 mostra uma visão geral da caracterização macroscópica das trincas. 


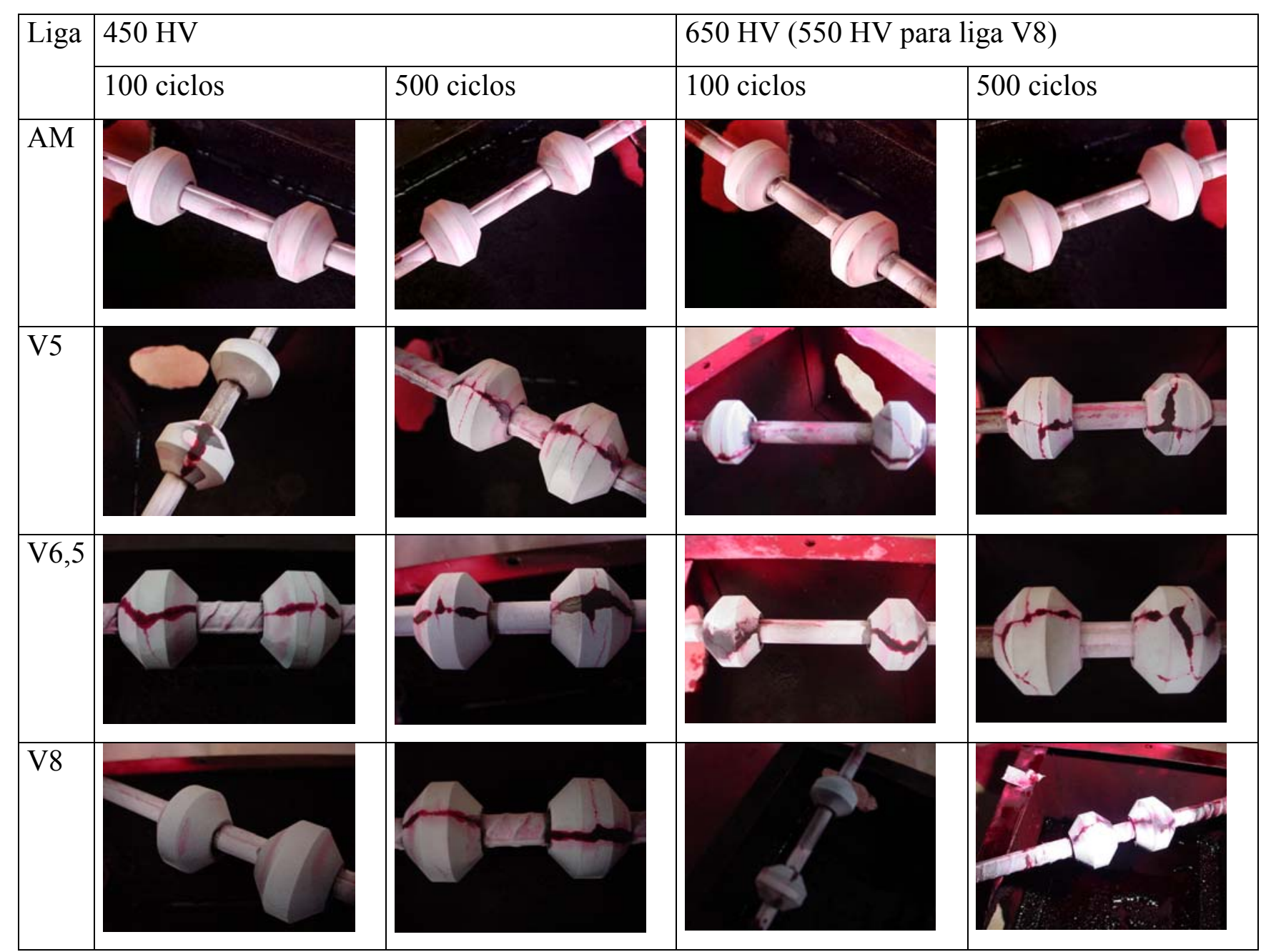

Figura 50 - Caracterização macroscópica das trincas dos corpos-de-prova da primeira série de experimentos. 


\section{b) Caracterização microscópica}

\section{Oxidação superficial}

O ensaio de fadiga térmica gera, além de trincas, a formação de uma camada de óxido superficial que é tanto mais espessa quanto maior for o tempo de exposição do corpo-de-prova à temperatura de ensaio. À medida que aumenta o número de ciclos, portanto, a espessura dessa camada de óxido aumenta. A figura 51 apresenta a camada de oxidação formada durante os ensaios de 100 e 500 ciclos do corpo-deprova V8/450.

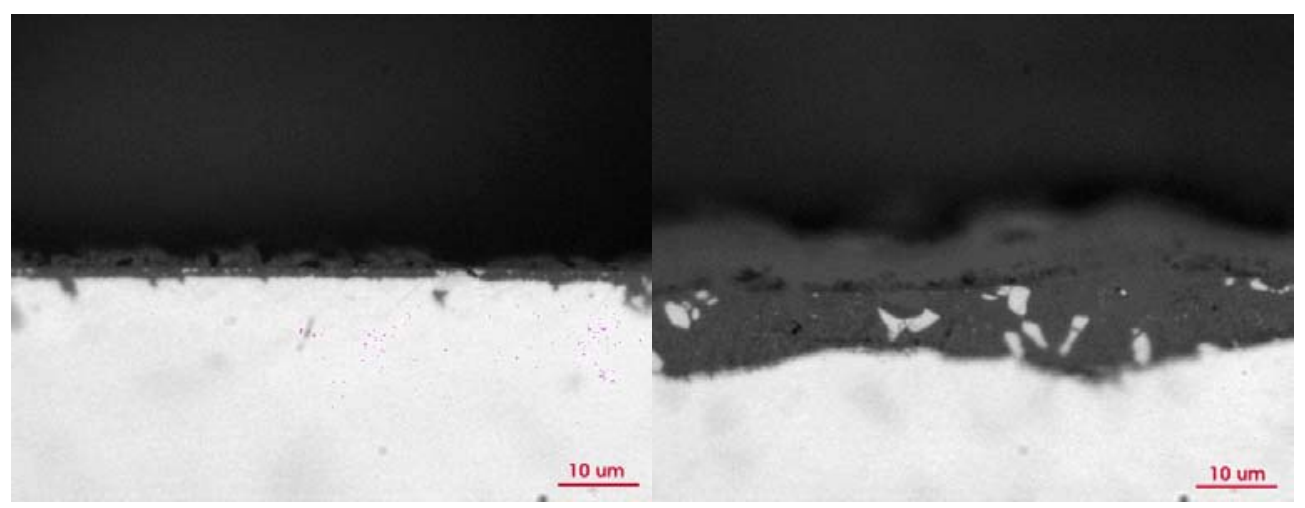

(a)

(b)

Figura 51 - Seção transversal do corpo-de-prova V8/450 ensaiado a (a) 100 ciclos e (b) 500 ciclos, mostrando a diferença na espessura da camada de oxidação formada durante o ensaio de fadiga térmica.

Observa-se que apenas parte da camada de óxido cresce da superfície para o interior do corpo-de-prova; em geral, a espessura desta parte da camada de óxido dos corpos-de-prova ensaiados a 100 ciclos é da ordem de $2 \mu \mathrm{m}$, ao passo que, no ensaio de 500 ciclos, a espessura é da ordem de $10 \mu \mathrm{m}$. Em virtude dessa diferença na espessura da camada de óxido, não se realizou a medição da quantidade de trincas nos corpos-de-prova ensaiados a 500 ciclos, pois a camada de óxido formada impede a contabilização de trincas com profundidade inferior a $10 \mu \mathrm{m}$ e, conseqüentemente, prejudica a comparação com os resultados dos ensaios a 100 ciclos. Além disso, nos corpos-de-prova ensaiados a 500 ciclos não é possível observar o sítio de nucleação de trinca. 
A oxidação na superfície dos corpos-de-prova é mais intensa na matriz do que nos carbonetos eutéticos, que continuam não oxidados mesmo quando a superfície é completamente oxidada (figura 51b). As trincas que propagam apenas no carboneto apresentam pouca oxidação, ao contrário das que propagam pela matriz, que possuem suas superfícies intensamente oxidadas.

Densidade de trincas (Dt)

A tabela 10 apresenta os valores de densidade de trincas (trincas $/ \mathrm{mm}$ ) dos corpos-de-prova da primeira série de experimentos ensaiados a 100 ciclos.

Tabela 10 - Densidade de trincas dos corpos-de-prova da primeira série de experimentos ensaiados a 100 ciclos

\begin{tabular}{|c|c|c|}
\hline \multirow{2}{*}{ Corpo-de-prova } & \multicolumn{2}{|c|}{ Densidade de trincas (trincas/mm) } \\
\cline { 2 - 3 } & $\mathrm{Cp} 1$ & $\mathrm{Cp} 2$ \\
\hline $\mathrm{AM} / 450 / 100$ & 7,8 & 8,6 \\
\hline $\mathrm{V} 5 / 450 / 100$ & 14,7 & 20 \\
\hline $\mathrm{V} 6,5 / 450 / 100$ & 15,3 & 12,2 \\
\hline $\mathrm{V} 8 / 450 / 100$ & 20 & 21,2 \\
\hline $\mathrm{AM} / 650 / 100$ & 3,3 & 3,4 \\
\hline $\mathrm{V} 5 / 650 / 100$ & 4,1 & 10,1 \\
\hline $\mathrm{V} 6,5 / 650 / 100$ & 4,7 & 5,1 \\
\hline $\mathrm{V} 8 / 550 / 100$ & 12,6 & 13,5 \\
\hline
\end{tabular}

A figura 52 apresenta a variação do valor de densidade de trincas em função da fração volumétrica de carboneto eutético MC para cada dureza nominal inicial da matriz. 


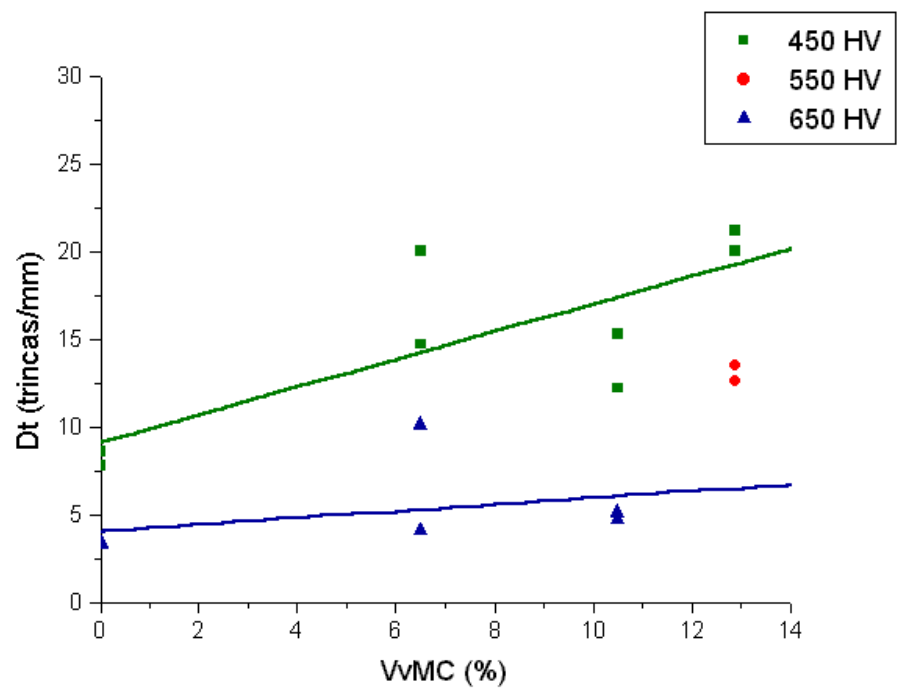

Figura 52 - Densidade de trincas em função da fração volumétrica de carboneto eutético MC para o ensaio de 100 ciclos.

De uma forma geral, é possível afirmar que:

i) $\mathrm{O}$ aumento da fração volumétrica de carboneto $\mathrm{MC}$ promove o aumento da densidade de trincas. A liga V6,5 (10,5\% de MC) representa uma exceção a este comportamento geral para ambas as durezas de matriz;

ii) A densidade de trincas aumenta com a diminuição da dureza da matriz, independentemente da fração volumétrica de carboneto eutético MC. O resultado referente ao corpo-de-prova V8/550 ratifica este comportamento geral ao indicar uma situação intermediária entre o corpo-de-prova V8/450 e um possível V8/650.

Os resultados mostram que, embora os carbonetos eutéticos sejam sítios favoráveis à nucleação de trincas, sua ausência não impede essa nucleação.

As figuras 53 e 54 mostram trincas de fadiga térmica nos corpos-de-prova da liga AM (sem carbonetos eutéticos). 


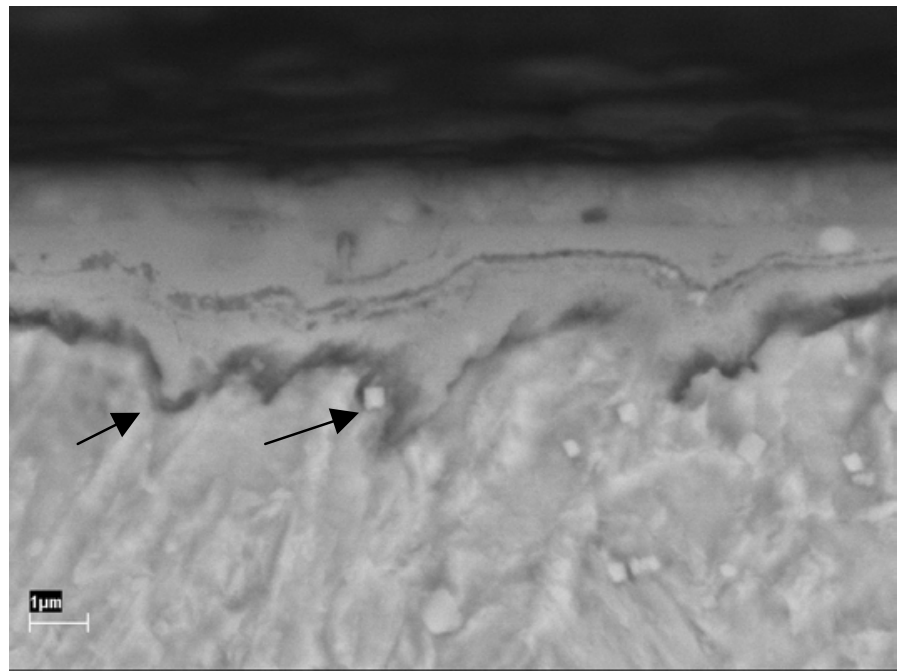

Figura 53 - Seção transversal do corpo-de-prova AM/450/100, mostrando trincas nucleadas na matriz. MEV - elétrons secundários.

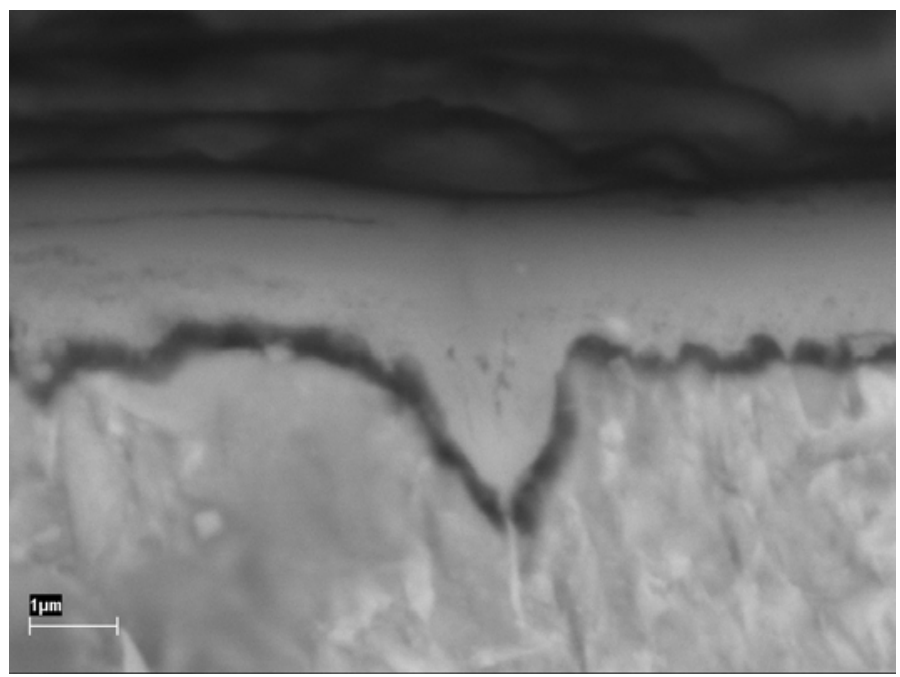

Figura 54 - Seção transversal do corpo-de-prova AM/650/100, mostrando o detalhe de uma trinca de fadiga térmica nucleada na matriz e com as superfícies totalmente oxidadas. MEV - elétrons retro-espalhados.

Nas ligas com carbonetos eutéticos, a nucleação das trincas ocorre nos carbonetos eutéticos, na interface carboneto/matriz e, ainda, na própria matriz (figura $55)$. 


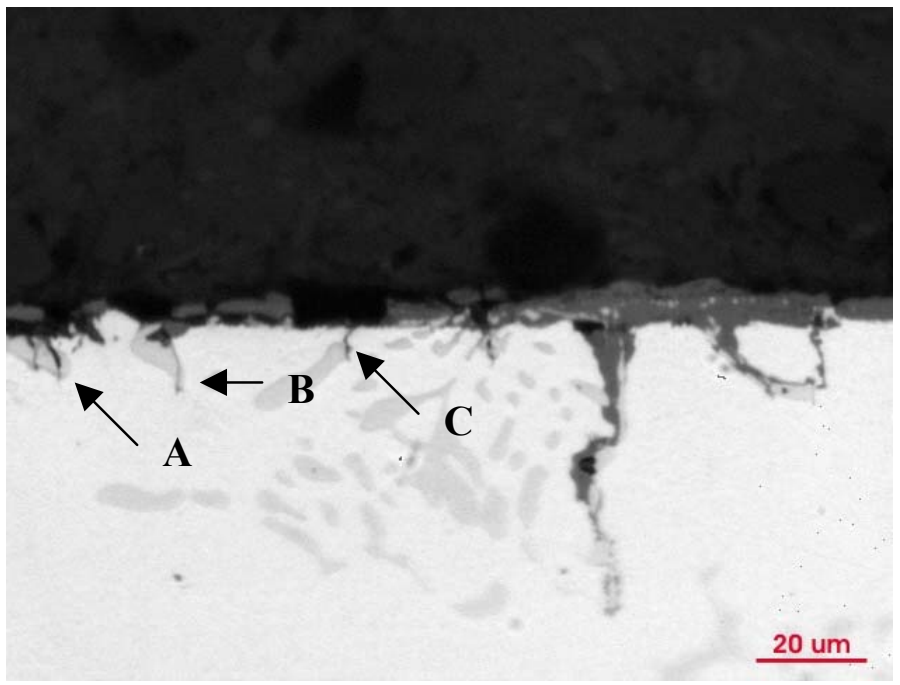

Figura 55 - Seção transversal do corpo-de-prova V5/450/100, mostrando a nucleação da trinca de fadiga térmica em: A - Carboneto eutético, B - Interface carboneto/matriz e $\mathbf{C}$ - Matriz. Sem ataque.

Entretanto, a situação mais comum é aquela em que a nucleação ocorre no próprio carboneto e, nesse caso, observam-se ramificações ou trincas secundárias (figuras 56 e 57). Outra situação freqüente é a presença trincas em carbonetos MC subsuperficiais (figura 57).

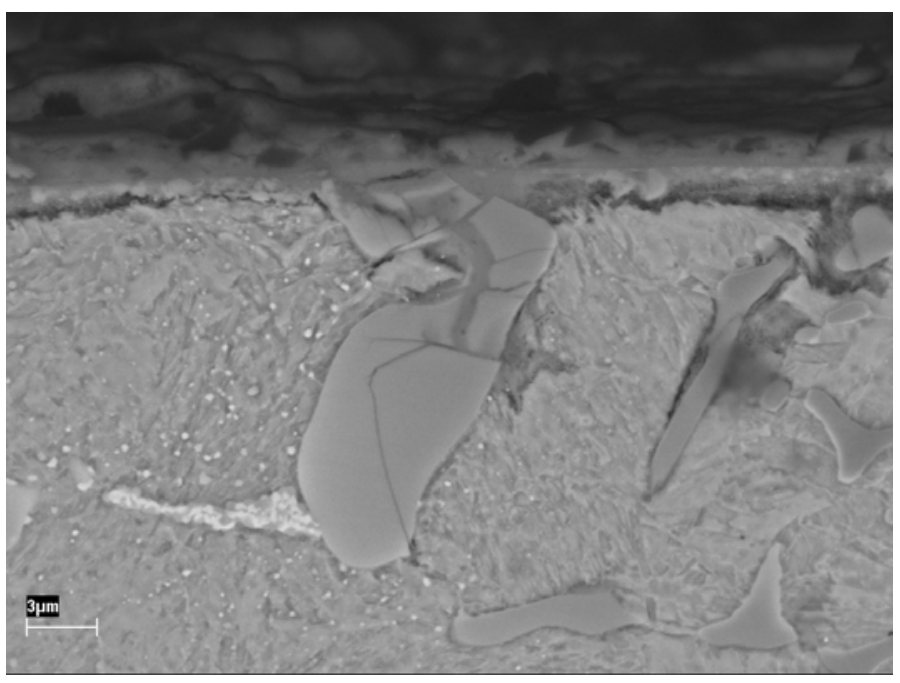

Figura 56 - Seção transversal do corpo-de-prova V5/450/100, mostrando um carboneto eutético MC com trincas ramificadas localizado na superfície do corpo-deprova. MEV - elétrons retro-espalhados. 


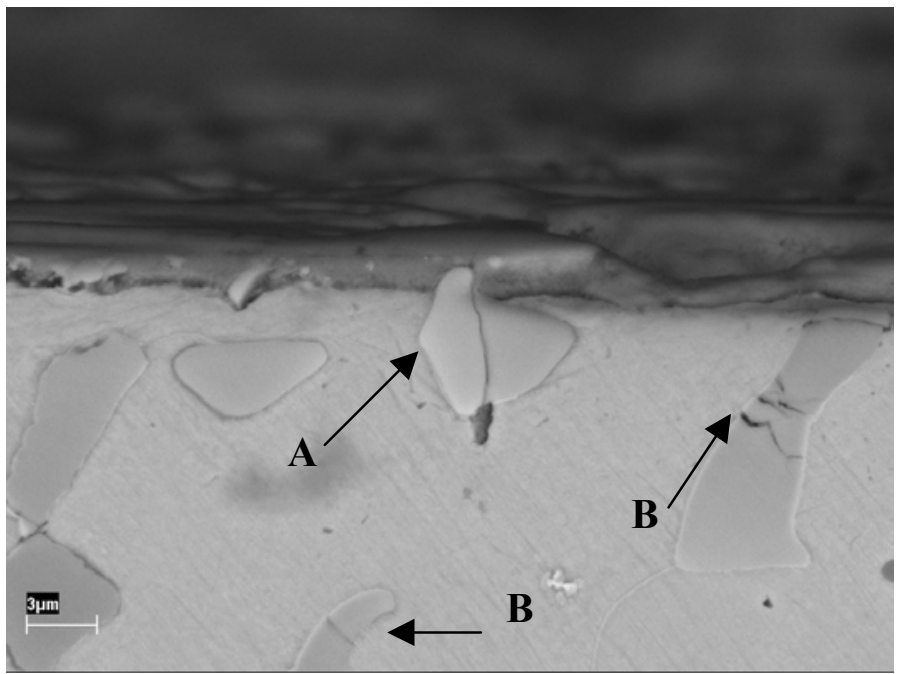

Figura 57 - Seção transversal do corpo-de-prova V8/450/100, mostrando trincas em carbonetos eutéticos MC localizados na superfície (seta A) e em carbonetos eutéticos MC subsuperficiais (seta B). MEV - elétrons retro-espalhados.

$\mathrm{O}$ carboneto eutético $\mathrm{M}_{2} \mathrm{C}$ também é um sítio favorável à nucleação de trincas (figura 58). Entretanto, dado que sua fração volumétrica é significativamente menor do que a do carboneto $\mathrm{MC}$, a nucleação de trinca no carboneto $\mathrm{M}_{2} \mathrm{C}$ é menos freqüente.

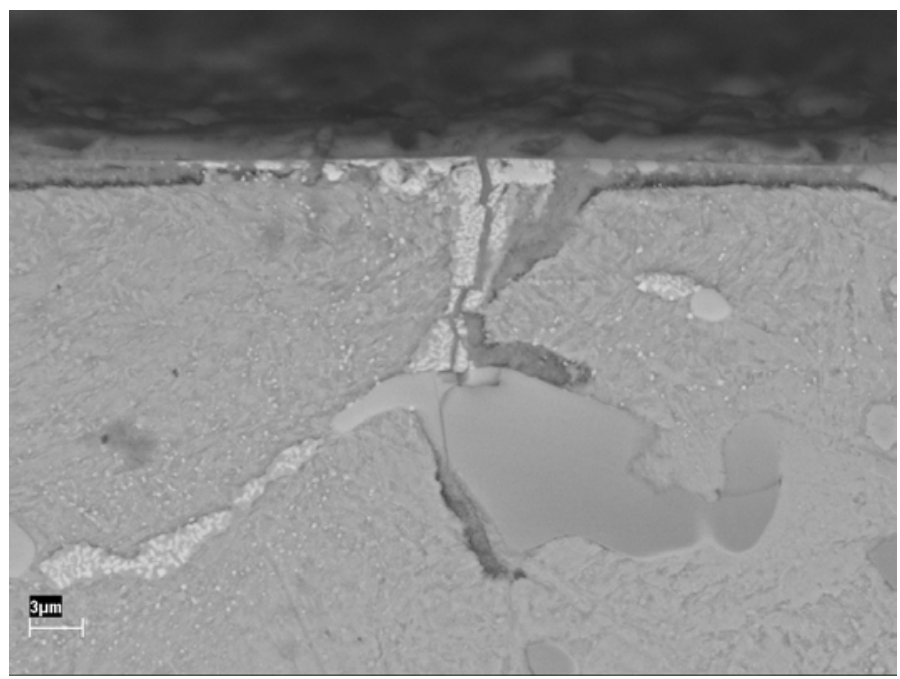

Figura 58 - Seção transversal do corpo-de-prova V5/450/100, mostrando uma trinca nucleada em um carboneto eutético $\mathrm{M}_{2} \mathrm{C}$. MEV - elétrons retro-espalhados. 
$\underline{\text { Profundidade máxima de trinca (Pmáx) }}$

A tabela 11 apresenta os valores de profundidade máxima de trinca dos corpos-de-prova da primeira série de experimentos ensaiados a 100 e a 500 ciclos.

Tabela 11 - Profundidade máxima de trinca dos corpos-de-prova da primeira série de experimentos

\begin{tabular}{|c|c|c|c|c|}
\hline \multirow{2}{*}{ Corpo-de-prova } & \multicolumn{4}{|c|}{ Profundidade máxima de trinca $(\mu \mathrm{m})$} \\
\cline { 2 - 5 } & \multicolumn{2}{|c|}{100 ciclos } & \multicolumn{2}{c|}{500 ciclos } \\
\cline { 2 - 5 } & $\mathrm{Cp} 1$ & $\mathrm{Cp} 2$ & $\mathrm{Cp} 1$ & $\mathrm{Cp} 2$ \\
\hline $\mathrm{AM} / 450$ & 28 & 48 & 147 & 124 \\
\hline $\mathrm{AM} / 650$ & 32 & 19 & 172 & 146 \\
\hline $\mathrm{V} 5 / 450$ & 143 & 94 & 127 & n.d. \\
\hline $\mathrm{V} 5 / 650$ & 140 & 49 & 242 & 204 \\
\hline $\mathrm{V} 6,5 / 450$ & 192 & 115 & 205 & 191 \\
\hline $\mathrm{V} 6,5 / 650$ & 124 & 119 & 255 & 301 \\
\hline $\mathrm{V} 8 / 450$ & 66 & 93 & 189 & 290 \\
\hline $\mathrm{V} 8 / 550$ & 63 & 55 & 140 & 93 \\
\hline
\end{tabular}

n.d.: não determinada

A figura 59 apresenta a variação do valor de profundidade máxima de trinca em função da fração volumétrica de carboneto MC. 


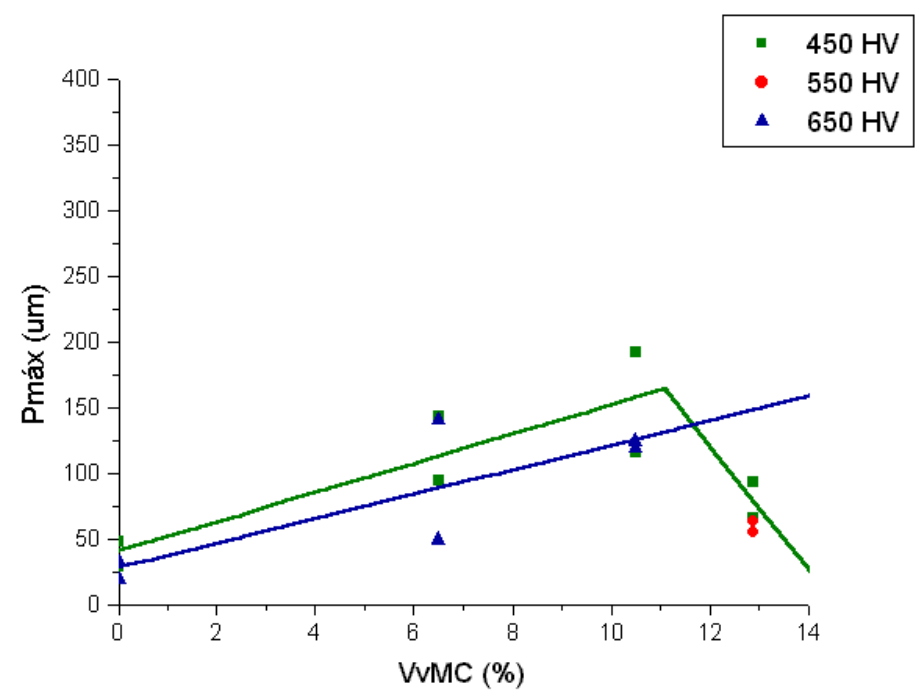

(a)

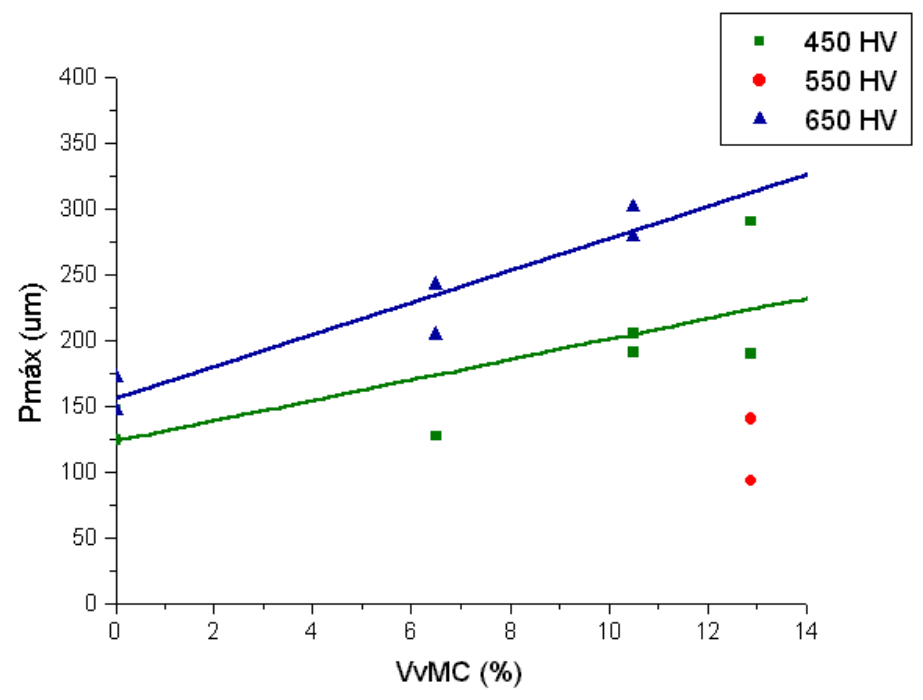

(b)

Figura 59 - Profundidade máxima de trinca em função da fração volumétrica de carboneto eutético MC: (a) 100 ciclos e (b) 500 ciclos.

De uma forma geral, é possível afirmar que:

i) $\mathrm{O}$ aumento da fração volumétrica de carboneto $\mathrm{MC}$ até 10,5\% (liga V6,5) promove o aumento da profundidade de trinca, independentemente do valor de dureza e do número de ciclos.

ii) Para a liga V8 (12,9\% de carboneto eutético MC) a profundidade máxima de trinca diminui em relação à da liga V6,5 $(10,5 \%$ de 
MC). O corpo-de-prova V8/450/500 representa a exceção a este comportamento geral.

iii) No ensaio de 100 ciclos não se observa um efeito nítido da dureza da matriz sobre Pmáx, apesar da pequena diferença entre as linhas de tendência.

iv) No ensaio de 500 ciclos, as ligas com dureza inicial de $650 \mathrm{HV}$ apresentaram maior profundidade de trinca do que as ligas com dureza inicial de $450 \mathrm{HV}$. O resultado dos corpos-de-prova V8/550/500 representa uma exceção.

A propagação da trinca ocorre principalmente pela interface carboneto/matriz e, em algumas situações, pelo próprio carboneto.

A figura 60 mostra o caminho de propagação de trinca no corpo-de-prova V6,5/450/500.

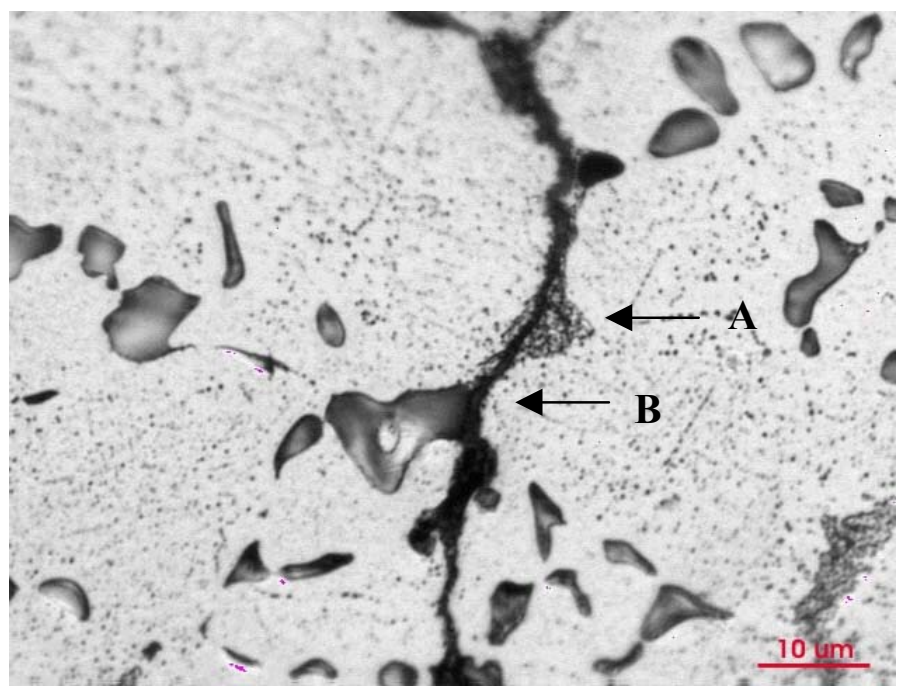

Figura 60 - Seção transversal do corpo-de-prova V6,5/450/500, mostrando o caminha de propagação de trinca: $\mathbf{A}$ - pela interface carboneto $\mathrm{M} 2 \mathrm{C} /$ matriz e $\mathbf{B}$ pela interface carboneto MC/matriz. Ataque: Eletrolítico + Grosbeck.

A figura 61 mostra o caminho de propagação de uma trinca no corpo-deprova $\mathrm{V} 8 / 550 / 500$. 


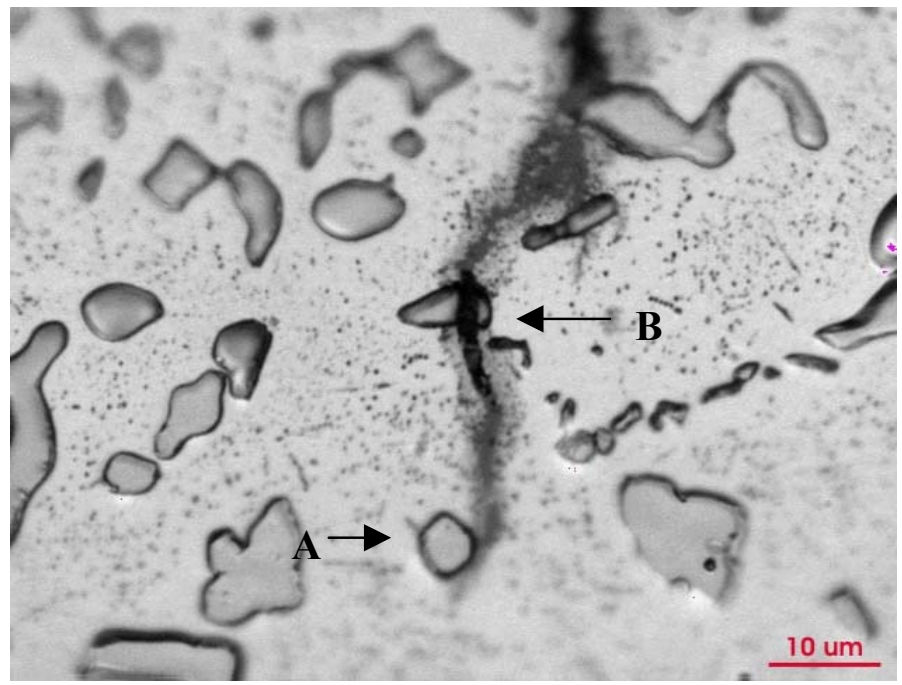

Figura 61 - Seção transversal do corpo-de-prova V8/550/500, mostrando o caminho de propagação de trinca: $\mathbf{A}$ - pela interface carboneto/matriz e $\mathbf{B}$ - através do próprio carboneto. Ataque: Eletrolítico + Grosbeck.

A tabela 12 mostra os valores de taxa de propagação da maior trinca calculados com base nos resultados de profundidade máxima da primeira série de experimentos. 
Tabela 12 - Taxa de propagação da maior trinca dos corpos-de-prova da primeira série de experimentos

\begin{tabular}{|c|c|c|c|c|}
\hline \multirow{2}{*}{ Corpo-de-prova } & \multicolumn{3}{|c|}{ Taxa de propagação $(\mu \mathrm{m} /$ ciclo) } \\
\cline { 2 - 6 } & \multicolumn{2}{|c|}{100 ciclos } & \multicolumn{2}{|c|}{500 ciclos } \\
\cline { 2 - 6 } & $\mathrm{Cp} 1$ & $\mathrm{Cp} 2$ & $\mathrm{Cp} 1$ & $\mathrm{Cp} 2$ \\
\hline $\mathrm{AM} / 450$ & 0,28 & 0,48 & 0,29 & 0,25 \\
\hline $\mathrm{AM} / 650$ & 0,32 & 0,19 & 0,34 & 0,29 \\
\hline $\mathrm{V} 5 / 450$ & 1,43 & 0,94 & 0,25 & n.d. \\
\hline $\mathrm{V} 5 / 650$ & 1,40 & 0,49 & 0,48 & 0,41 \\
\hline $\mathrm{V} 6,5 / 450$ & 1,92 & 1,15 & 0,41 & 0,38 \\
\hline $\mathrm{V} 6,5 / 650$ & 1,24 & 1,19 & 0,51 & 0,6 \\
\hline $\mathrm{V} 8 / 450$ & 0,66 & 0,93 & 0,38 & 0,58 \\
\hline $\mathrm{V} 8 / 550$ & 0,63 & 0,55 & 0,28 & 0,19 \\
\hline
\end{tabular}

n.d.: não determinada.

A figura 62 mostra a variação da taxa de propagação da maior trinca em função da fração volumétrica de carboneto eutético MC para os ensaios de 100 e 500 ciclos. 


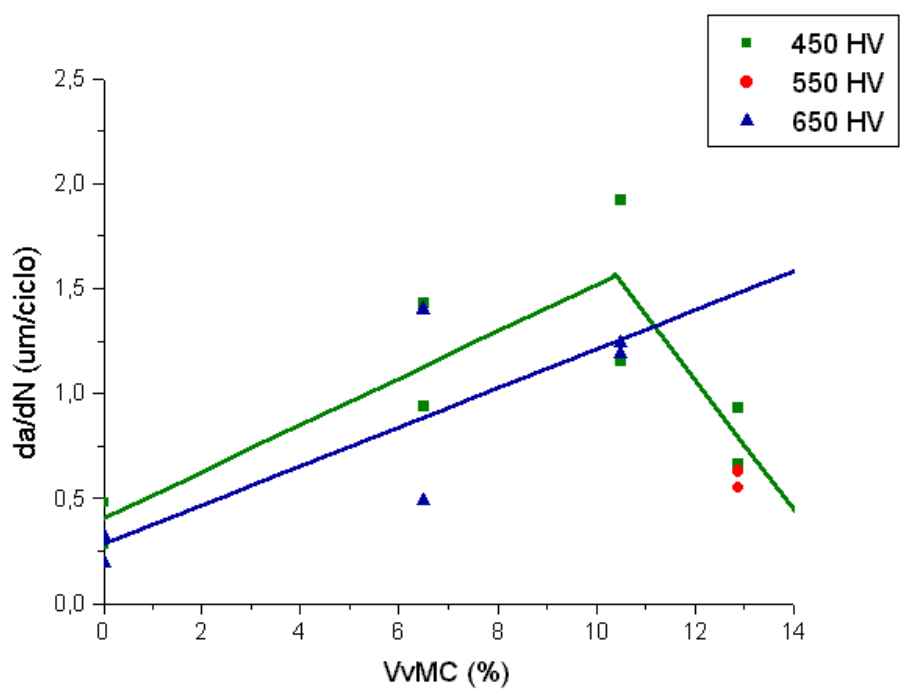

(a)

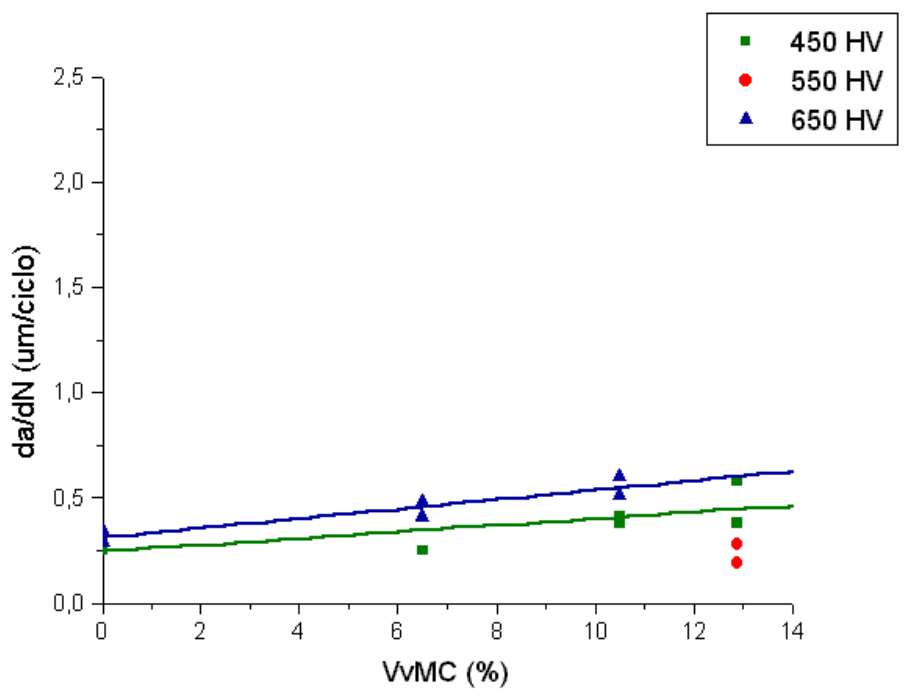

(b)

Figura 62 - Taxa de propagação da maior trinca em função da fração volumétrica de carboneto eutético MC: (a) 100 ciclos e (b) 500 ciclos.

De uma forma geral, pode-se afirmar que:

i)

A taxa de propagação da maior trinca diminui com o aumento do número de ciclos, independentemente da fração volumétrica de carbonetos e da dureza da matriz. 
ii) Para o ensaio de 100 ciclos, a taxa de propagação aumenta com o aumento da fração volumétrica de carboneto MC até 10,5\% (liga V6,5), independentemente da dureza da matriz.

iii) Para o ensaio de 100 ciclos, a taxa de propagação da liga com 12,9\% de carboneto $\mathrm{MC}$ (liga V8) diminuiu em relação à da liga com 10,5\% de carboneto MC (liga V6,5). O resultado do corpo-deprova V8/550/100 ratifica esse comportamento geral ao indicar uma situação intermediária entre o corpo-de-prova V8/450/100 e um possível V8/650/100.

iv) Para o ensaio de 500 ciclos, a taxa de propagação da maior trinca sofre pouca influência do aumento da fração volumétrica de carbonetos, independentemente da dureza da matriz.

\section{c) Microdureza da matriz}

A tabela 13 apresenta os valores médios de microdureza da matriz após os ensaios de 100 e 500 ciclos e os respectivos intervalos de variação (nível de confiança de 95\%). As medições foram efetuadas a 100, 200 e $300 \mu \mathrm{m}$ de distância da superfície externa dos corpos-de-prova. 
Tabela 13 - Valores médios de microdureza da matriz das ligas da primeira série de experimentos após os ensaios de 100 e 500 ciclos

\begin{tabular}{|c|c|c|c|c|c|c|c|}
\hline \multirow[t]{3}{*}{ Liga } & \multirow{3}{*}{$\begin{array}{c}\text { Dureza } \\
\text { nominal } \\
\text { inicial } \\
(\mathrm{HV}-50 \mathrm{~g})\end{array}$} & \multicolumn{6}{|c|}{ Dureza após ensaio $(\mathrm{HV}-50 \mathrm{~g})$} \\
\hline & & \multicolumn{3}{|c|}{100 ciclos } & \multicolumn{3}{|c|}{500 ciclos } \\
\hline & & $100 \mu \mathrm{m}$ & $200 \mu \mathrm{m}$ & $300 \mu \mathrm{m}$ & $100 \mu \mathrm{m}$ & $200 \mu \mathrm{m}$ & $300 \mu \mathrm{m}$ \\
\hline $\mathrm{AM}$ & \multirow{4}{*}{450} & $448 \pm 14,1$ & $492 \pm 5,48$ & $486 \pm 12,7$ & $410 \pm 29,8$ & $446 \pm 30,7$ & $448 \pm 27,4$ \\
\hline V5 & & $438 \pm 31,4$ & $437 \pm 44,9$ & $469 \pm 11,5$ & $429 \pm 29,2$ & $429 \pm 24,0$ & $450 \pm 14,9$ \\
\hline V6,5 & & $455 \pm 30,2$ & $461 \pm 27,1$ & $482 \pm 7,93$ & $374 \pm 19,3$ & $389 \pm 34,7$ & $429 \pm 23,8$ \\
\hline V8 & & $445 \pm 34,8$ & $452 \pm 30,9$ & $474 \pm 17,1$ & $411 \pm 40,4$ & $459 \pm 28,8$ & $479 \pm 41,3$ \\
\hline $\mathrm{AM}$ & \multirow{3}{*}{650} & $567 \pm 35,4$ & $620 \pm 18,2$ & $627 \pm 6,92$ & $415 \pm 28,5$ & $402 \pm 54,0$ & $446 \pm 26,8$ \\
\hline V5 & & $565 \pm 32,0$ & $619 \pm 14,3$ & $628 \pm 11,8$ & $382 \pm 59,6$ & $448 \pm 22,6$ & $467 \pm 22,6$ \\
\hline V6,5 & & $590 \pm 34,4$ & $623 \pm 31,1$ & $611 \pm 12,0$ & $392 \pm 52,7$ & $426 \pm 18,0$ & $432 \pm 23,9$ \\
\hline V8 & 550 & $465 \pm 33,5$ & $556 \pm 23,4$ & $550 \pm 18,7$ & $510 \pm 45,9$ & $481 \pm 53,2$ & $497 \pm 32,6$ \\
\hline
\end{tabular}

Observaram-se os seguintes comportamentos gerais:

i) Pequena queda da dureza da matriz a $100 \mu \mathrm{m}$ da superfície dos corpos-de-prova com dureza nominal inicial de $450 \mathrm{HV}$ ensaiados a 500 ciclos, notadamente na liga V6,5; nos ensaios a 100 ciclos, não houve alteração;

ii) Queda de dureza da matriz dos corpos-de-prova com dureza nominal inicial de $650 \mathrm{HV}$ após ensaio de 100 ciclos, independentemente da liga (queda maior na região a $100 \mu \mathrm{m}$ da superfície);

iii) Queda acentuada de dureza da matriz dos corpos-de-prova com dureza nominal inicial de 650 HV após ensaio de 500 ciclos, independentemente da liga. $\mathrm{O}$ valor final de dureza é equivalente ao valor de dureza nominal inicial de $450 \mathrm{HV}$; 
iv) A dureza da matriz dos corpos-de-prova da liga V8 com dureza nominal inicial de $550 \mathrm{HV}$ apresentou pequena queda somente após ensaio de 500 ciclos.

\subsection{Segunda série de experimentos}

Os resultados da segunda série de experimentos foram divididos em caracterização dos corpos-de-prova no estado inicial e caracterização dos corpos-deprova no estado final.

\subsubsection{Caracterização dos corpos-de-prova no estado inicial}

\section{a) Microestrutura}

\section{Caracterização qualitativa}

A evolução da microestrutura das ligas da segunda série de experimentos dáse, principalmente, pelo aumento da fração do eutético $\mathrm{M}_{2} \mathrm{C}$.

A liga M2 possui a mesma composição química da liga V8. Sua microestrutura é, portanto, a mesma da liga V8. A liga M3,5 diferencia-se da liga M2 pelo aumento da fração do eutético $\mathrm{M}_{2} \mathrm{C}$ e pelo aumento da fração de carbonetos $\mathrm{MC}$ constituídos por partículas idiomórficas (comparar as figuras 63 e 42).

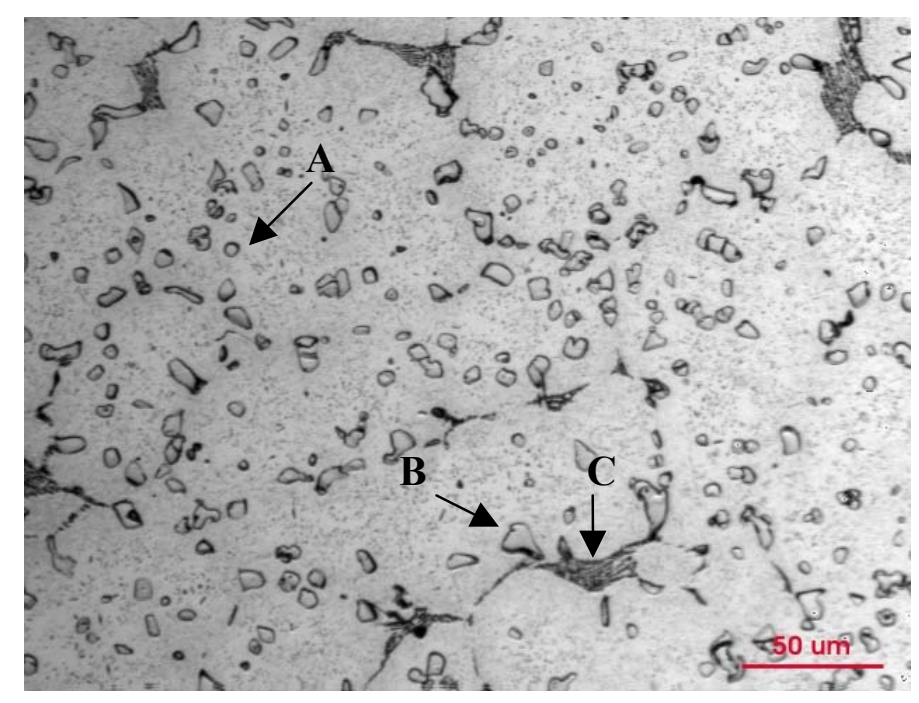

Figura 63 - Microestrutura da liga M3,5, mostrando a distribuição dos carbonetos eutéticos $\mathrm{MC}$ e $\mathrm{M}_{2} \mathrm{C}$. A- $\mathrm{MC}$ divorciado, B- $\mathrm{MC}$ irregular e C- $\mathrm{M}_{2} \mathrm{C}$ regular complexo. Ataque: Eletrolítico +Grosbeck. 


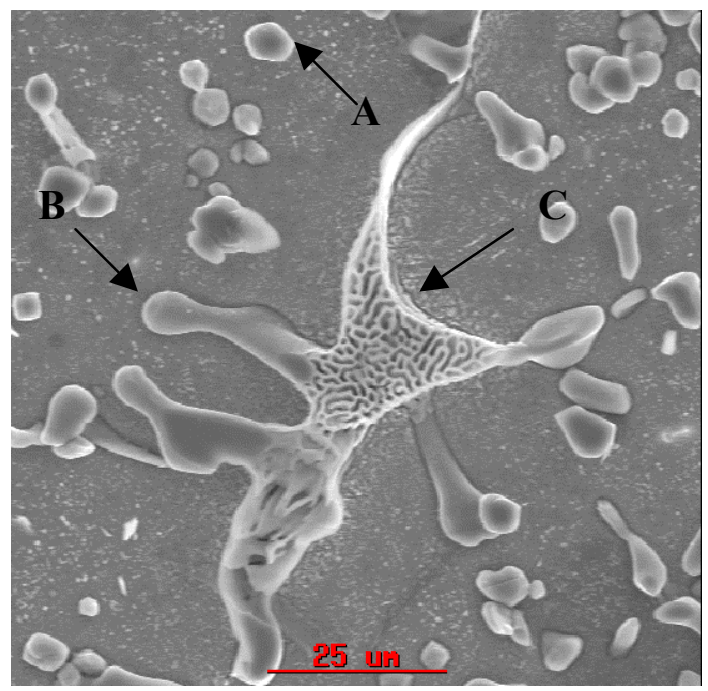

Figura 64 - Microestrutura da liga M3,5, mostrando detalhes dos carbonetos eutéticos $\mathrm{MC}$ e $\mathrm{M}_{2} \mathrm{C}$. A- $\mathrm{MC}$ divorciado, B- $\mathrm{MC}$ irregular e C- $\mathrm{M}_{2} \mathrm{C}$ regular complexo. MEV - elétrons secundários.

Na liga M5, uma liga ligeiramente hipereutética, houve a formação de carbonetos MC primários, cuja morfologia é caracterizada por seu aspecto dendrítico, além dos carbonetos eutéticos MC com morfologia idiomórfica. O eutético M2C é irregular, em que o carboneto apresenta a morfologia de plaquetas (figuras 65 e 66). 


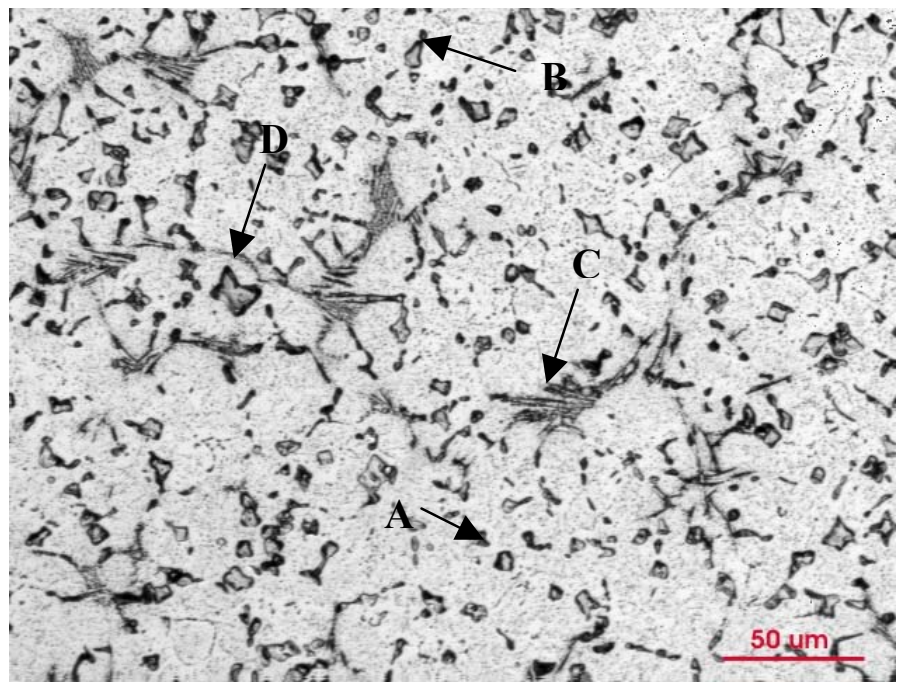

Figura 65 - Microestrutura da liga M5, mostrando a distribuição dos carbonetos eutéticos $\mathrm{MC}$ e $\mathrm{M} 2 \mathrm{C}$ e do carboneto $\mathrm{MC}$ primário. A- $\mathrm{MC}$ divorciado, B- $\mathrm{MC}$ irregular, C- $\mathrm{M}_{2} \mathrm{C}$ irregular e D- carboneto $\mathrm{MC}$ primário. Ataque: Eletrolítico+Grosbeck.

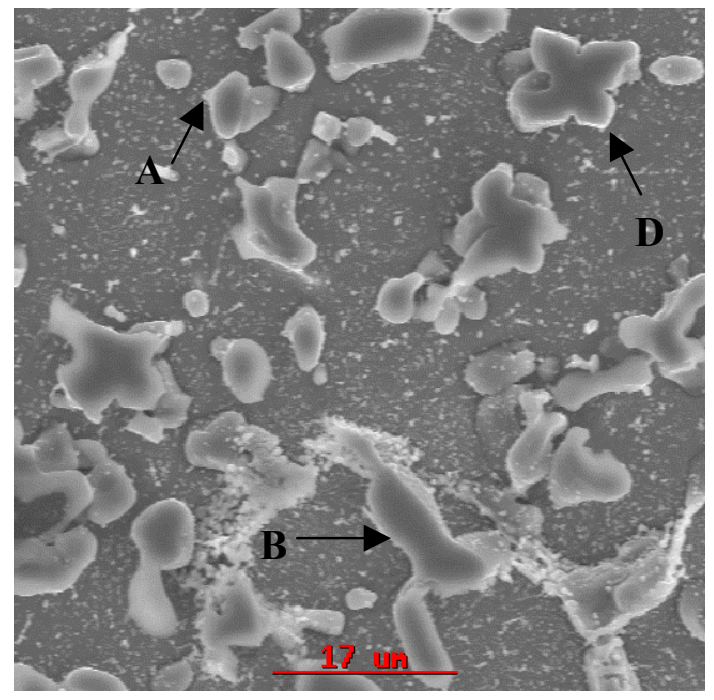

Figura 66 - Microestrutura da liga M5, mostrando detalhes dos carbonetos eutéticos $\mathrm{MC}$ e $\mathrm{M}_{2} \mathrm{C}$ e do carboneto $\mathrm{MC}$ primário. A- MC divorciado, B- $\mathrm{MC}$ irregular, C$\mathrm{M}_{2} \mathrm{C}$ regular complexo e D- MC primário. $\mathrm{MEV}$ - elétrons secundários.

A figura 67 mostra a evolução da distribuição dos carbonetos eutéticos com o aumento do teor de molibdênio para as ligas da segunda série de experimentos. 


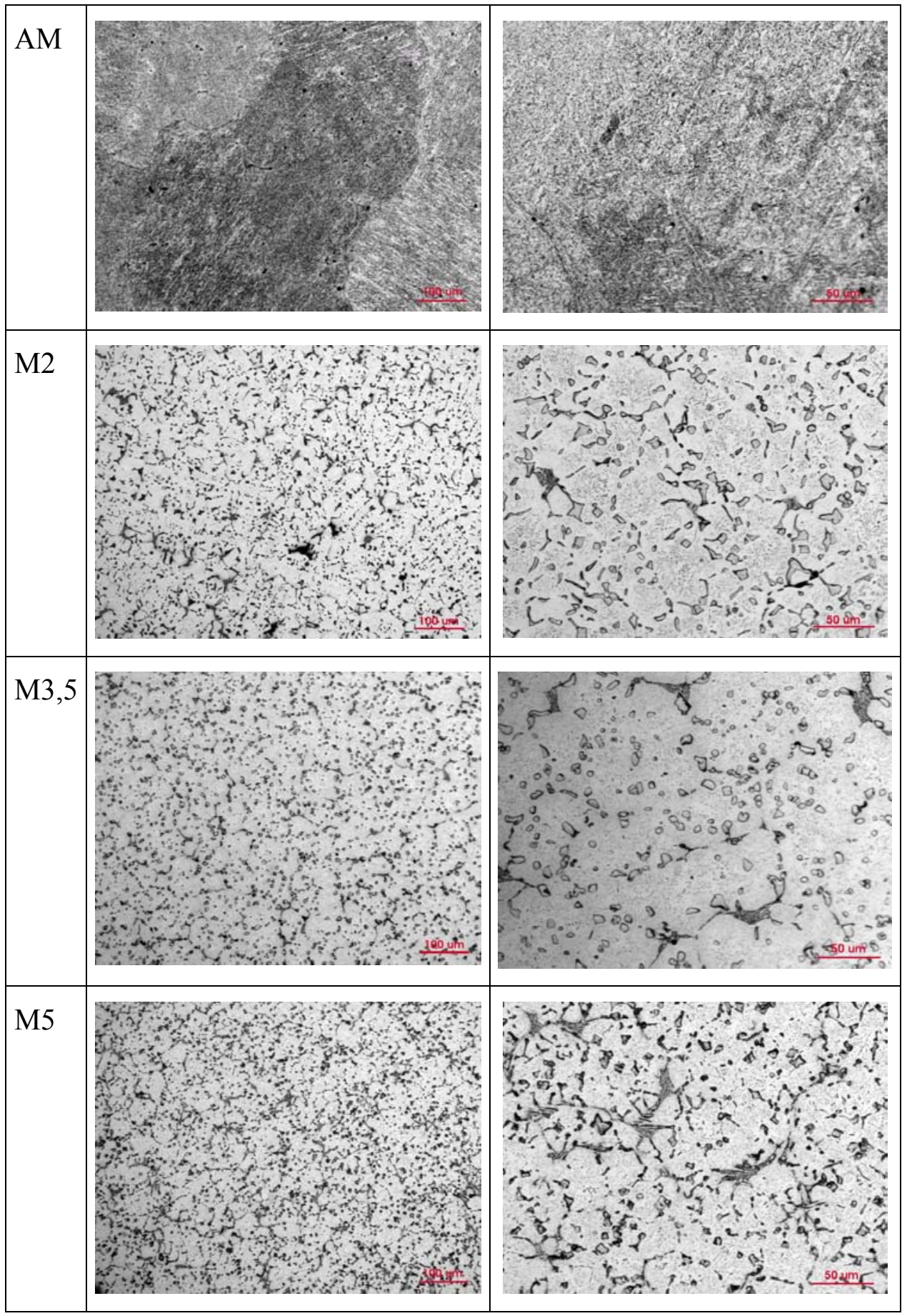

Figura 67 - Evolução da microestrutura das ligas da segunda série de experimentos.

A matriz dessas ligas é qualitativamente semelhante à das ligas da primeira série de experimentos. 


\section{Caracterização quantitativa}

A tabela 14 apresenta os valores médios de fração volumétrica dos carbonetos eutéticos das ligas da segunda série de experimentos. Os intervalos de variação foram determinados para um nível de confiança de $95 \%$.

Tabela 14 - Valores médios de fração volumétrica de carbonetos eutéticos das ligas da segunda série de experiências

\begin{tabular}{|c|c|c|c|}
\hline \multirow{2}{*}{ Liga } & \multicolumn{3}{|c|}{ Fração volumétrica de carbonetos eutéticos } \\
\cline { 2 - 4 } & Total & MC & M2C \\
\hline M2 & $0,137 \pm 0,002$ & $0,129 \pm 0,003$ & $0,008 \pm 0,002$ \\
\hline M3,5 & $0,147 \pm 0,002$ & $0,121 \pm 0,004$ & $0,026 \pm 0,004$ \\
\hline M5 & $0,135 \pm 0,003$ & $0,104 \pm 0,005$ & $0,031 \pm 0,005$ \\
\hline
\end{tabular}

Os resultados da tabela mostram que:

i) A fração volumétrica total de carbonetos eutéticos não varia significativamente entre as três ligas;

ii) $\mathrm{O}$ aumento do teor de molibdênio promove a diminuição da fração volumétrica de carbonetos eutéticos $\mathrm{MC}$;

iii) $\mathrm{O}$ aumento do teor de molibdênio promove o aumento da fração volumétrica de carbonetos eutéticos $\mathrm{M}_{2} \mathrm{C}$.

A tabela 15 apresenta os valores médios de fator de forma $(\mathrm{F})$ e diâmetro equivalente $\left(\phi_{\mathrm{eq}}\right)$ dos carbonetos eutéticos $\mathrm{MC}$, bem como de distância livre média entre eles $\left(D_{m}\right)$ e continuidade da rede de carbonetos $(C)$. Os intervalos de variação foram determinados para um nível de confiança de 95\%. 
Tabela 15 - Fator de forma, diâmetro equivalente, distância livre média e continuidade do carboneto eutético MC das ligas da segunda série de experimentos

\begin{tabular}{|c|c|c|c|c|}
\hline Liga & $\mathrm{F}$ & $\phi_{\mathrm{eq}}(\mu \mathrm{m})$ & $\mathrm{C}\left(\mu \mathrm{m}^{2}\right)$ & $\mathrm{D}_{\mathrm{m}}(\mu \mathrm{m})$ \\
\hline M2 & $2,00 \pm 0,02$ & $6,79 \pm 0,08$ & $25,6 \pm 0,43$ & $29,8 \pm 2,43$ \\
\hline M3,5 & $1,86 \pm 0,03$ & $4,53 \pm 0,10$ & $26,4 \pm 0,63$ & $37,8 \pm 4,24$ \\
\hline M5 & $2,12 \pm 0,03$ & $7,37 \pm 0,13$ & $26,6 \pm 0,41$ & $31,6 \pm 2,50$ \\
\hline
\end{tabular}

A figura 68 apresenta a variação dos valores médios de fator de forma e diâmetro equivalente do carboneto eutético $\mathrm{MC}$ em função de sua fração volumétrica.

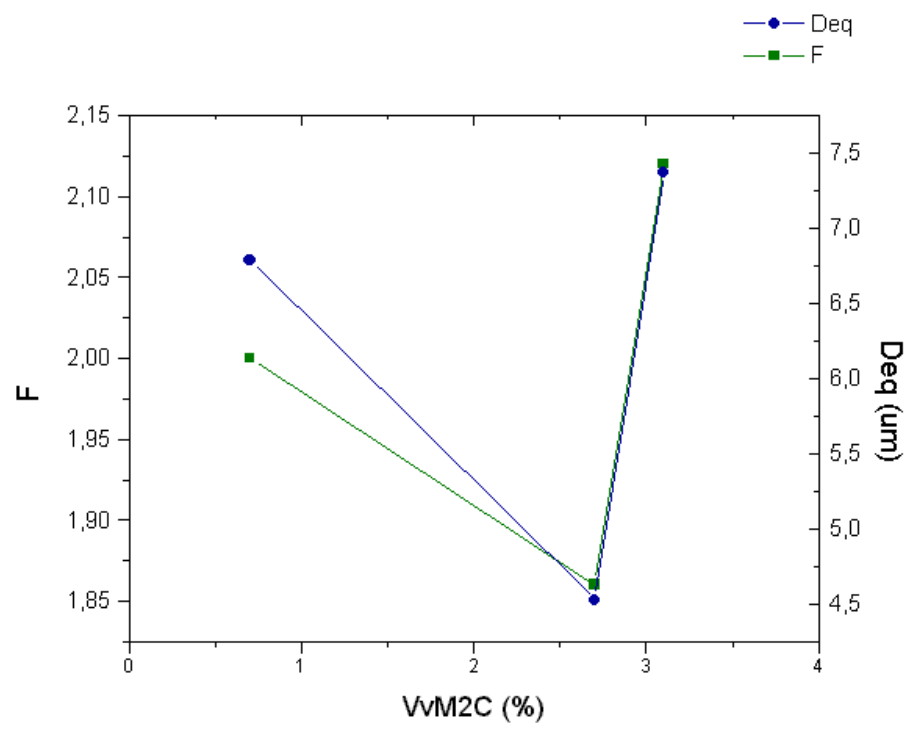

Figura 68 - Diâmetro equivalente e fator de forma do carboneto eutético $\mathrm{MC}$ em função da sua fração volumétrica.

Observa-se que o fator de forma e o diâmetro equivalente do carboneto eutético MC apresentam um mínimo para liga M3,5.

A figura 69 apresenta a variação dos valores médios da distância livre média e da continuidade do carboneto eutético MC em função de sua fração volumétrica. 


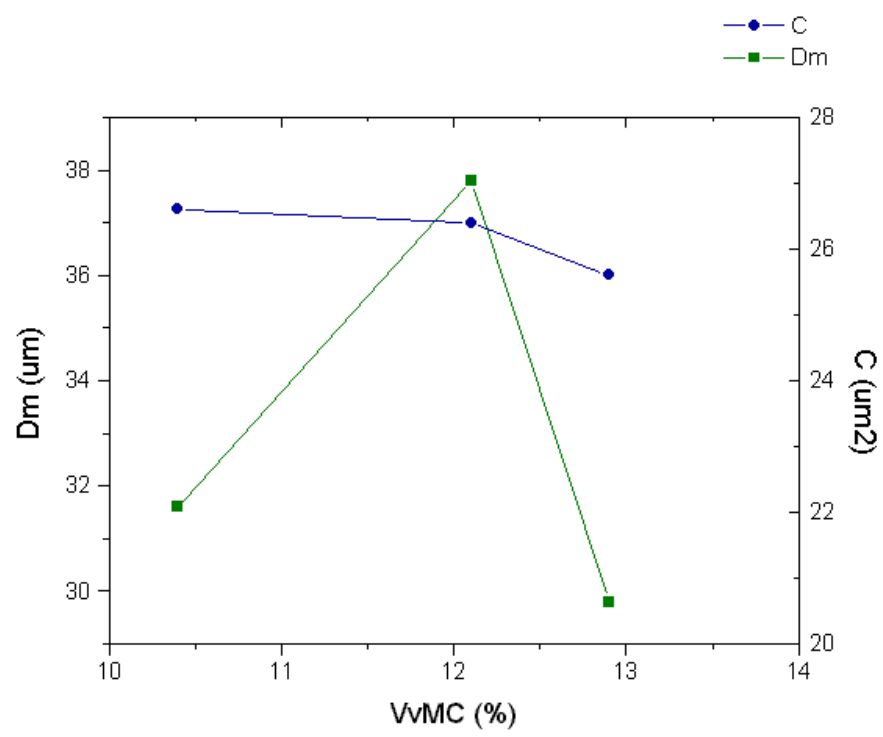

Figura 69 - Distância livre média e continuidade do carboneto eutético em função de fração volumétrica de carboneto eutético MC.

Observa-se que a distância livre média do carboneto eutético MC apresenta um máximo para a liga M3,5 (12,1\% de $\mathrm{MC}$ e $2,7 \%$ de $\left.\mathrm{M}_{2} \mathrm{C}\right)$ e que a continuidade de carbonetos não sofre influência significativa da fração volumétrica de carboneto eutético.

\section{b) Microdureza da matriz}

A tabela 16 apresenta os valores médios de microdureza da matriz dos corpos-de-prova da segunda série de experimentos e os respectivos intervalos de variação determinados para um nível de confiança de 95\%.

Tabela 16 - Valores médios de microdureza da matriz dos corpos-de-prova da segunda série de experimentos.

\begin{tabular}{|c|c|}
\hline Liga & Dureza $(\mathrm{HV}-50 \mathrm{~g})$ \\
\hline AM & $450 \pm 9,30$ \\
\hline M2 & $492 \pm 31,9$ \\
\hline M3,5 & $430 \pm 6,70$ \\
\hline M5 & $471 \pm 15,0$ \\
\hline
\end{tabular}




\subsubsection{Caracterização dos corpos-de-prova no estado final}

\section{a) Caracterização macroscópica (ensaio de líquido penetrante)}

De uma forma geral, os resultados de caracterização macroscópica das trincas mostrou dois tipos de comportamento:

i) Os corpos-de-prova da liga $\mathrm{AM}$ (sem carbonetos eutéticos) não apresentaram trincas macroscópicas, independentemente da dureza da matriz e do número de ciclos;

ii) Os corpos-de-prova das demais ligas (com carbonetos eutéticos na microestrutura) apresentaram trincas radial e circunferencial, com exceção dos corpos-de-prova M2/450/100 (dois corpos-de-prova), M3,5/450/100 (dois corpos-de-prova) e M3,5/450/500 (um corpode-prova).

Na maior parte dos corpos-de-prova as trincas são únicas e sem ramificações, sendo que a trinca circunferencial propagou-se preferencialmente pela pista do corpo-de-prova.

A figura 70 apresenta um quadro geral da caracterização macroscópica das trincas. 


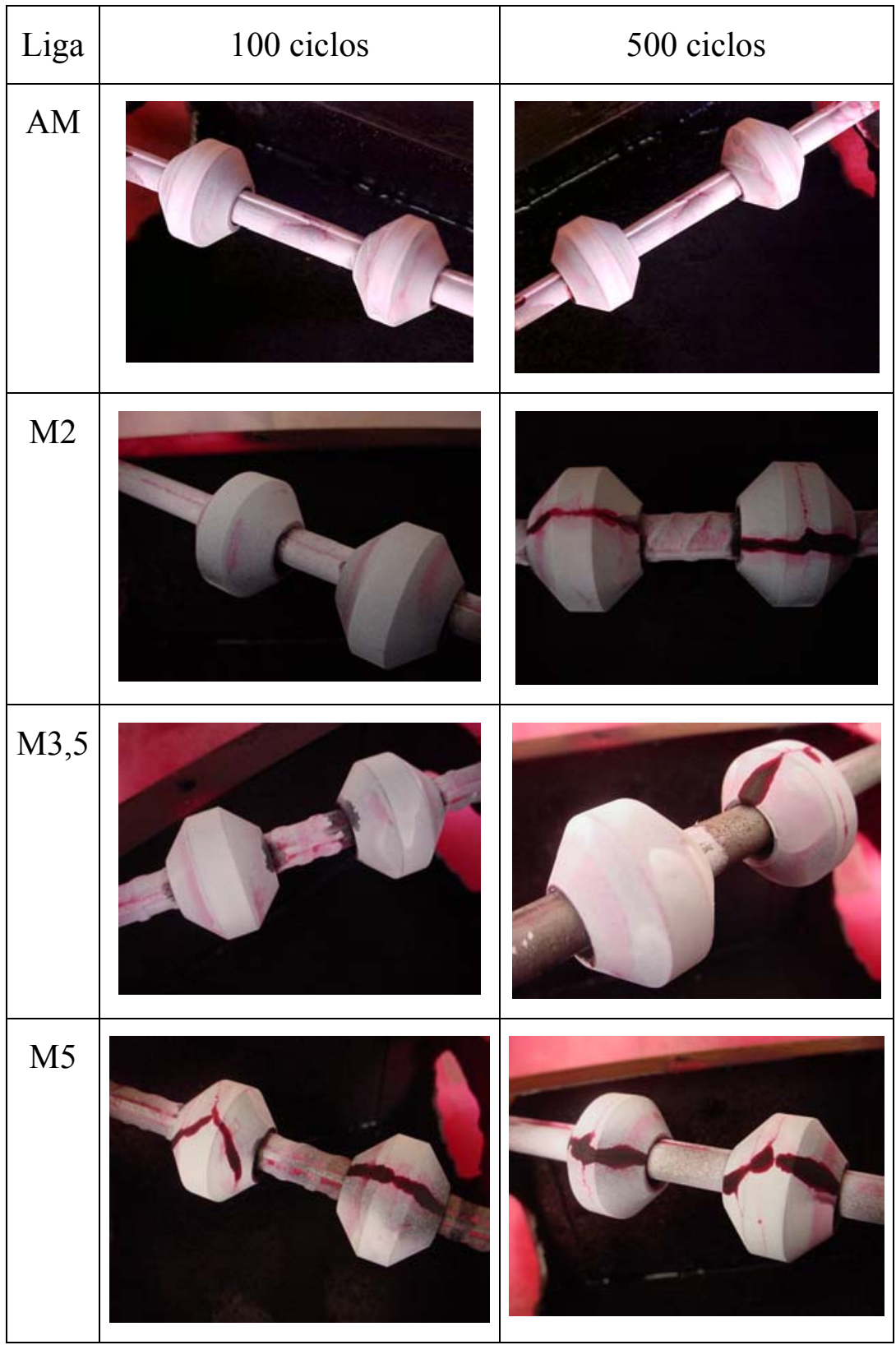

Figura 70 - Caracterização macroscópica das trincas dos corpos-de-prova da segunda série de experimentos. 


\section{b) Caracterização microscópica}

\section{Oxidação superficial}

Com relação à oxidação superficial, valem as mesmas considerações tecidas para a primeira série de experimentos.

\section{$\underline{\text { Densidade de trincas }}$}

A tabela 17 mostra os valores de densidade de trincas (trincas $/ \mathrm{mm}$ ) dos corpos-de-prova da segunda série de experimentos.

Tabela 17 - Densidade de trincas dos corpos-de-prova da segunda série de experimentos ensaiados a 100 ciclos

\begin{tabular}{|c|c|c|}
\hline \multirow{2}{*}{ Liga } & \multicolumn{2}{|c|}{ Densidade de trincas (trincas/mm) } \\
\cline { 2 - 3 } & $\mathrm{Cp} 1$ & $\mathrm{Cp} 2$ \\
\hline AM & 7,8 & 8,6 \\
\hline M2 & 20 & 21,2 \\
\hline M3,5 & 12,3 & 18,8 \\
\hline M5 & 11,6 & 17,2 \\
\hline
\end{tabular}

A figura 71 apresenta a variação da densidade de trincas em função da fração volumétrica de carboneto eutético $\mathrm{M}_{2} \mathrm{C}$. 


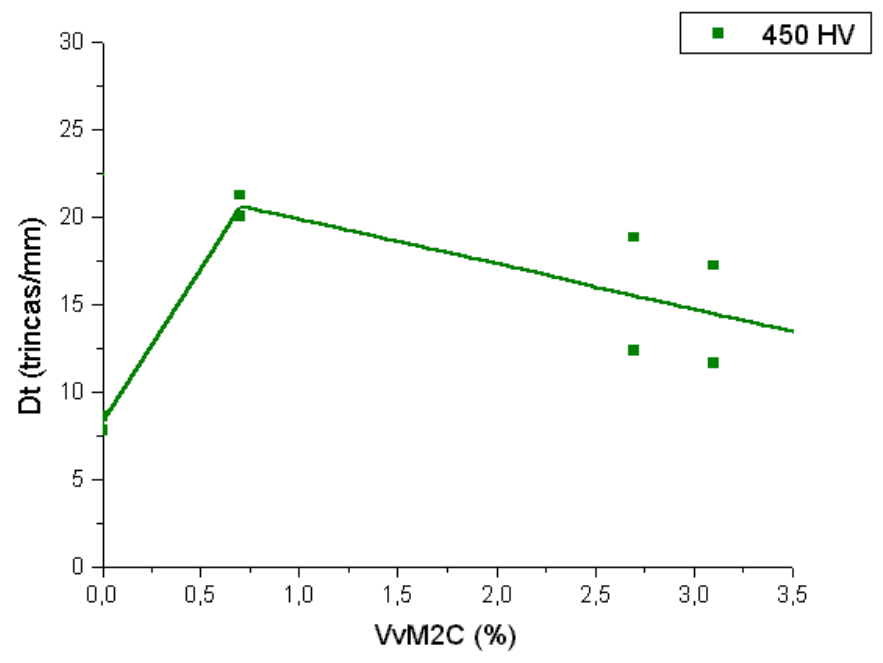

Figura 71 - Densidade de trincas em função da fração volumétrica de carboneto eutético M2C para o ensaio de 100 ciclos.

De uma forma geral, pode-se- afirmar que:

i) A densidade de trincas diminui com o aumento da fração volumétrica de carboneto eutético $\mathrm{M}_{2} \mathrm{C}$;

ii) A densidade de trincas da liga sem carboneto eutético é menor do que a das demais ligas (com carboneto eutético na microestrutura).

A nucleação de trincas ocorre nos carbonetos eutéticos, na interface matriz/carboneto e, ainda, na própria matriz (figura 72). 


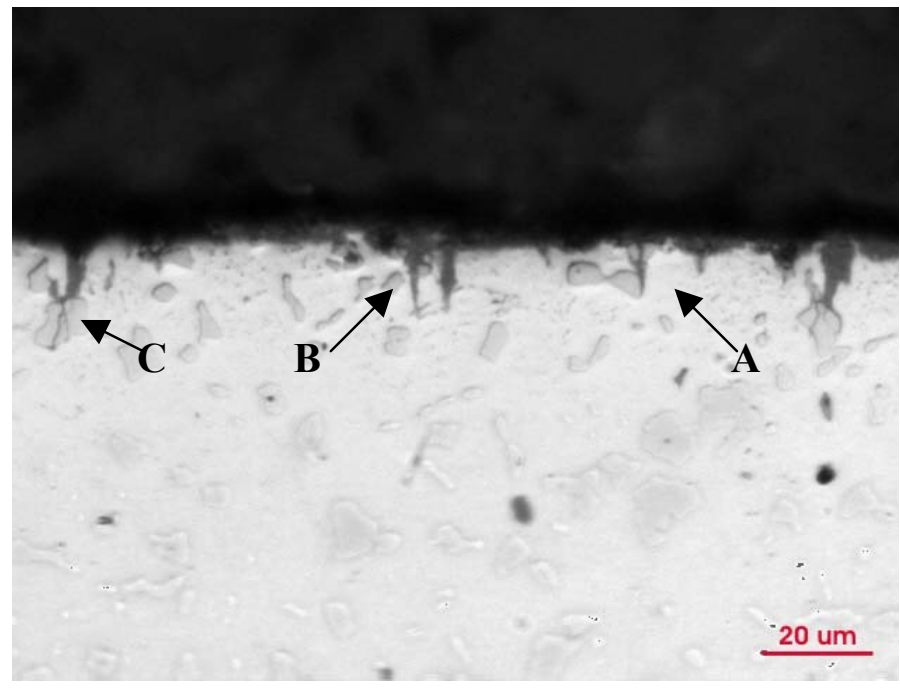

Figura 72 - Seção transversal do corpo-de-prova M5/450/500, mostrando os sítios de nucleação de trinca de fadiga térmica. A - Carboneto eutético, B - Interface carboneto/matriz e C - Matriz. Sem ataque.

Entretanto, novamente, a situação mais comum é a nucleação no próprio carboneto em que se observam ramificações ou trincas secundárias. Além disso, nas ligas dessa série, também é freqüente a presença de carbonetos trincados abaixo da superfície. As duas situações são apresentadas nas figuras 73 e 74 .

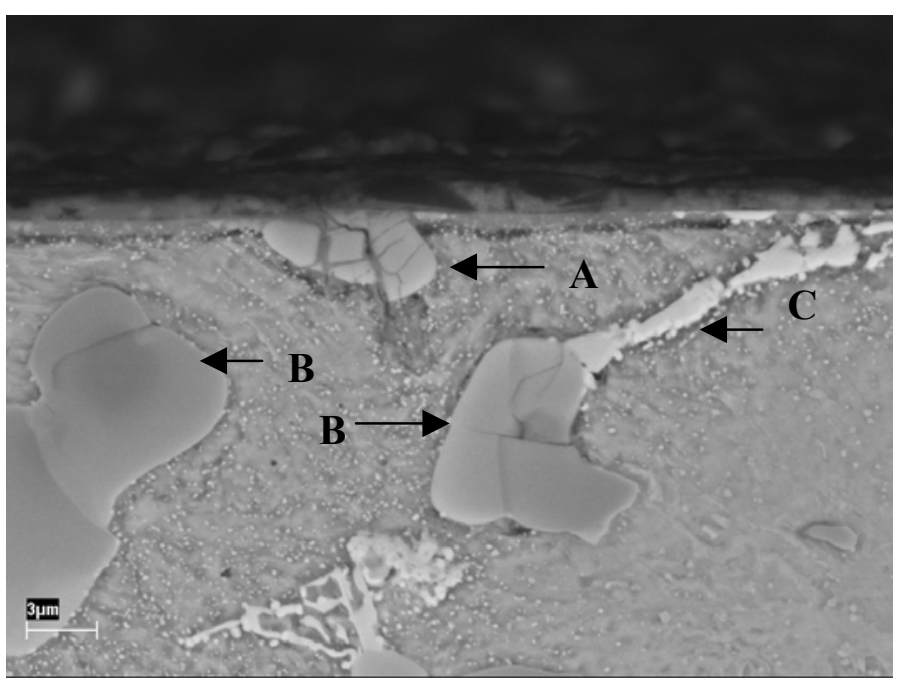

Figura 73 - Seção transversal do corpo-de-prova M3,5/450/100, mostrando trincas em carboneto eutético MC localizado na superfície (A), trinca em carboneto eutético MC localizado abaixo da superfície (B) e carboneto eutético $\mathrm{M}_{2} \mathrm{C}$ (C). MEV elétrons retro-espalhados. 


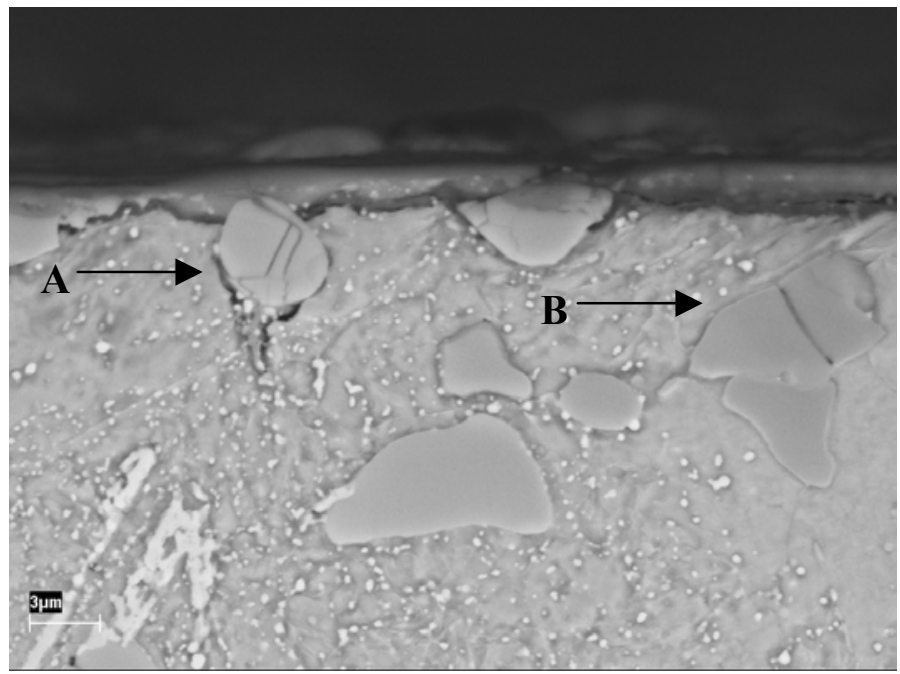

Figura 74 - Seção transversal do corpo-de-prova M5/450/100, mostrando trincas em carboneto eutético MC localizado na superfície (A) e trinca em carboneto eutético MC localizado abaixo da superfície (B). MEV - elétrons retro-espalhados.

A figura 75 mostra a propagação de uma trinca até um carboneto eutético localizado abaixo da superfície.

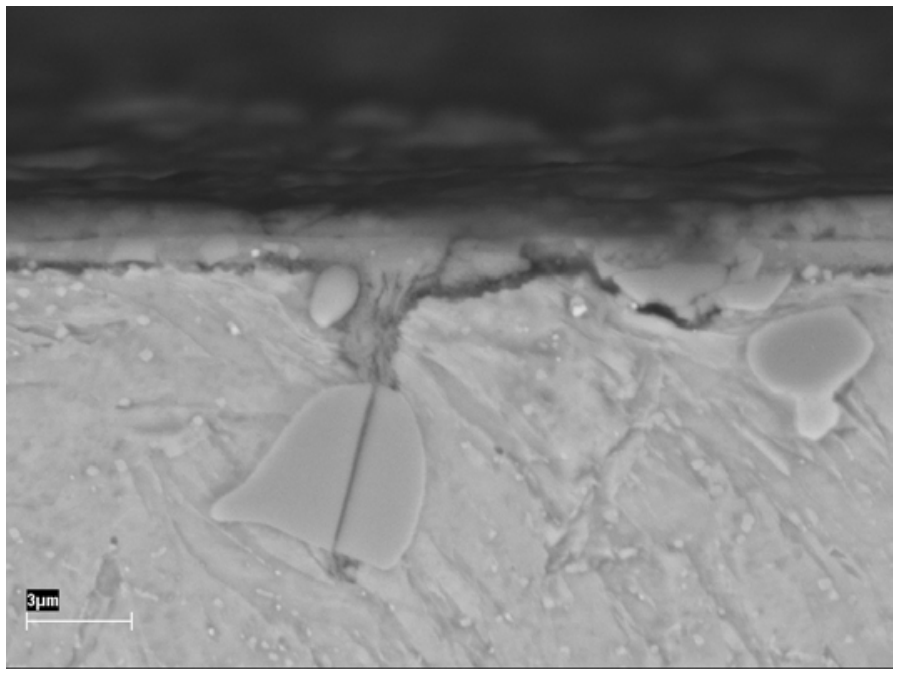

Figura 75 - Seção transversal do corpo-de-prova M3,5/450/100, mostrando uma trinca nucleada na matriz e sua propagação até o carboneto eutético MC. MEV elétrons retro-espalhados. 
$\mathrm{O}$ carboneto $\mathrm{M}_{2} \mathrm{C}$ também é um sítio favorável à nucleação de trincas. Entretanto, dado que sua fração volumétrica é significativamente inferior à do carboneto $\mathrm{MC}$, a nucleação de trinca nesse carboneto é menos freqüente.

\section{Profundidade máxima de trinca}

A tabela 18 apresenta os valores de profundidade máxima de trinca dos corpos-de-prova da segunda série de experimentos ensaiados a 100 e 500 ciclos.

Tabela 18 - Profundidade máxima de trinca dos corpos-de-prova da segunda série de experimentos

\begin{tabular}{|c|c|c|}
\hline \multirow{2}{*}{ Corpo-de-prova } & \multicolumn{2}{|c|}{ Profundidade máxima de trinca $(\mu \mathrm{m})$} \\
\cline { 2 - 3 } & $\mathrm{Cp} 1$ & $\mathrm{Cp} 2$ \\
\hline $\mathrm{AM} / 450 / 100$ & 28 & 48 \\
\hline $\mathrm{AM} / 450 / 500$ & 147 & 124 \\
\hline $\mathrm{M} 2 / 450 / 100$ & 66 & 93 \\
\hline $\mathrm{M} 2 / 450 / 500$ & 189 & 290 \\
\hline $\mathrm{M} 3,5 / 450 / 100$ & 56 & 97 \\
\hline $\mathrm{M} 3,5 / 450 / 500$ & 107 & 237 \\
\hline $\mathrm{M} 5 / 450 / 100$ & 32 & 97 \\
\hline $\mathrm{M} 5 / 450 / 500$ & 211 & 267 \\
\hline
\end{tabular}

A figura 76 apresenta a variação da profundidade máxima de trinca em função da fração volumétrica de carboneto eutético $\mathrm{M}_{2} \mathrm{C}$. 


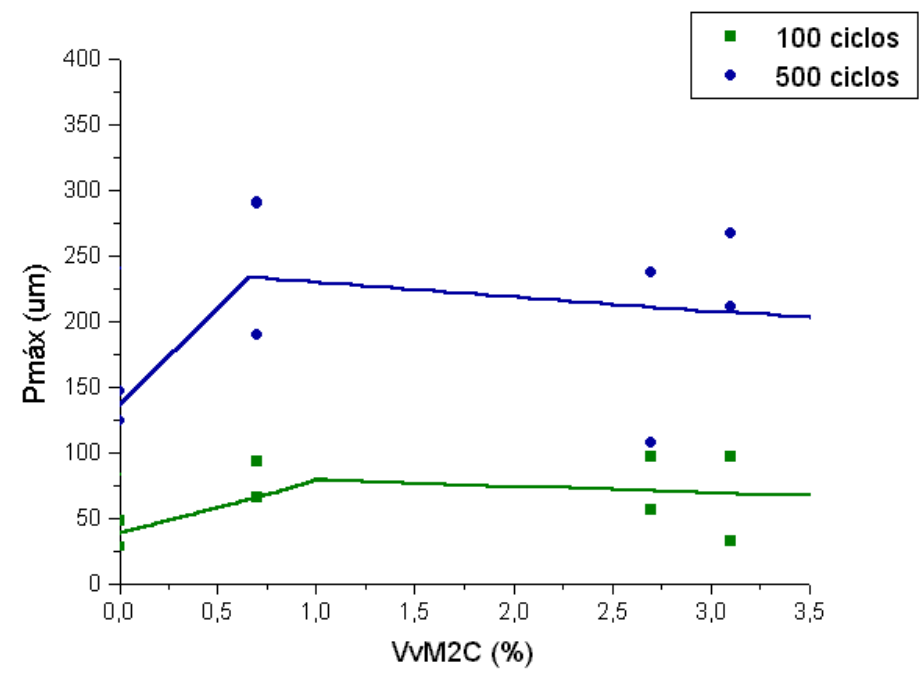

Figura 76 - Profundidade máxima de trinca em função da fração volumétrica de carboneto eutético $\mathrm{M}_{2} \mathrm{C}$.

De uma forma geral, pode-se afirmar que a profundidade máxima de trinca apresentou pouca variação com o aumento da fração volumétrica de carboneto eutético $\mathrm{M}_{2} \mathrm{C}$, independentemente do número de ciclos;

A propagação da trinca ocorre predominantemente pela interface carboneto/matriz e, em alguns casos, pelo próprio carboneto. A figura 77 mostra o caminho de propagação da trinca no corpo-de-prova M5/450/500. 


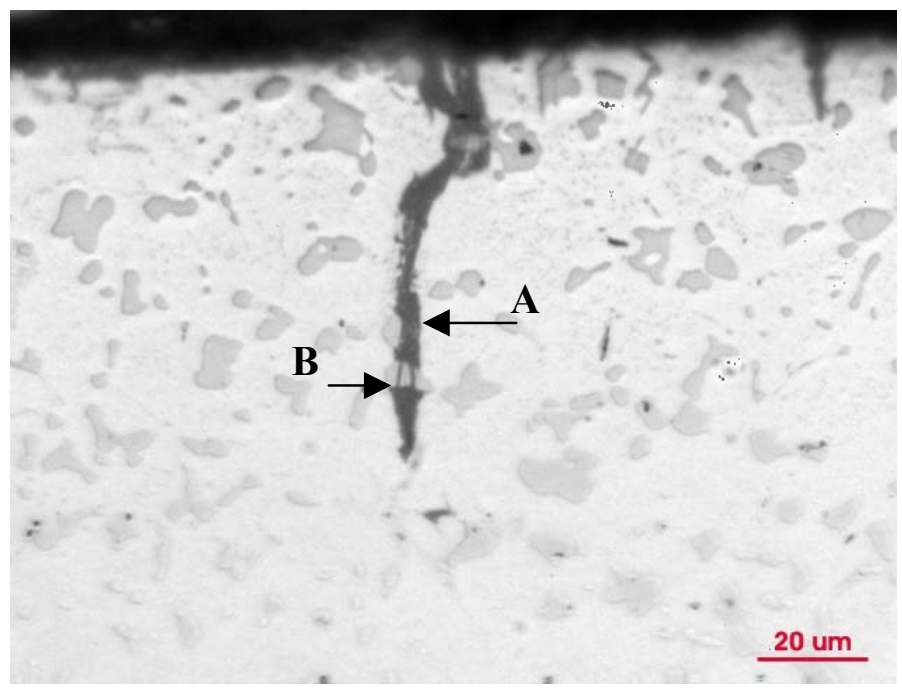

Figura 77 - Seção transversal do corpo-de-prova M5/450/500, mostrando a propagação da trinca: A - pela interface carboneto/matriz e B - pelo próprio carboneto. Sem ataque.

A tabela 19 mostra os valores de taxa de propagação da maior trinca calculados com base nos resultados da segunda série de experimentos.

Tabela 19 - Taxa de propagação da maior trinca dos corpos-de-prova da segunda série de experimentos

\begin{tabular}{|c|c|c|}
\hline \multirow{2}{*}{ Corpo-de-prova } & \multicolumn{2}{|c|}{$\mathrm{da} / \mathrm{dN}(\mu \mathrm{m} /$ ciclo $)$} \\
\cline { 2 - 3 } & $\mathrm{Cp} 1$ & $\mathrm{Cp} 2$ \\
\hline $\mathrm{AM} / 450 / 100$ & 0,28 & 0,48 \\
\hline $\mathrm{AM} / 450 / 500$ & 0,25 & 0,29 \\
\hline $\mathrm{M} 2 / 450 / 100$ & 0,66 & 0,93 \\
\hline $\mathrm{M} 2 / 450 / 500$ & 0,38 & 0,58 \\
\hline $\mathrm{M} 3,5 / 450 / 100$ & 0,56 & 0,97 \\
\hline $\mathrm{M} 3,5 / 450 / 500$ & 0,21 & 0,47 \\
\hline $\mathrm{M} 5 / 45 / 100$ & 0,32 & 0,97 \\
\hline $\mathrm{M} 5 / 450 / 500$ & 0,53 & 0,42 \\
\hline
\end{tabular}


A figura 78 , mostra a variação da taxa de propagação da maior trinca em função da fração volumétrica de carboneto eutético $\mathrm{M}_{2} \mathrm{C}$.

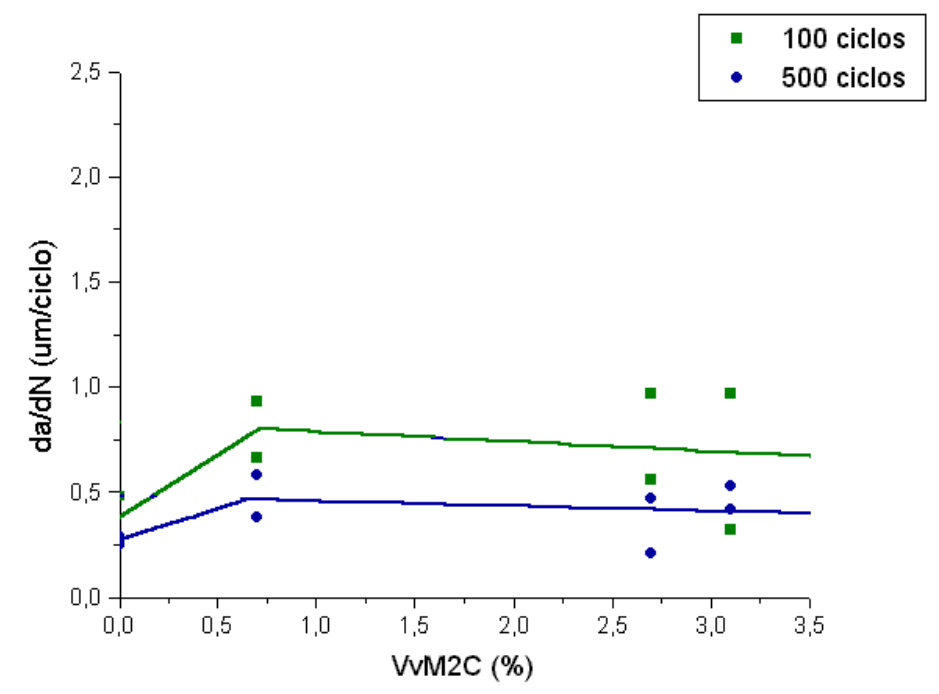

Figura 78 - Taxa de propagação da maior trinca em função da fração volumétrica de carboneto eutético $\mathrm{M}_{2} \mathrm{C}$.

De uma forma geral, pode-se afirmar que:

i) A taxa de propagação da maior trinca diminui com o aumento do número de ciclos, independentemente da fração volumétrica de carbonetos.

ii) A taxa de propagação varia pouco com o aumento da fração volumétrica de carboneto eutético $\mathrm{M}_{2} \mathrm{C}$, independentemente do número de ciclos.

\section{c) Microdureza da matriz}

Em virtude dos resultados apresentados para a microdureza da matriz dos corpos-de-prova da primeira série de experimentos, que não indicaram diminuição de dureza nos corpos-de-prova com dureza nominal inicial de $450 \mathrm{HV}$, independentemente do número de ciclos, as medições de microdureza da matriz dessas ligas após o ensaio de fadiga térmica não foram realizadas. 


\subsection{Terceira série de experimentos}

Os resultados da terceira série de experimentos foram divididos em caracterização dos corpos-de-prova no estado inicial e caracterização dos corpos-deprova no estado final.

\subsubsection{Caracterização dos corpos-de-prova no estado inicial}

Os resultados desta caracterização são os mesmos relatados na primeira série de experimentos, uma vez que os corpos-de-prova foram usinados a partir dos mesmos semi-acabados fundidos.

\subsubsection{Caracterização dos corpos-de-prova no estado final}

\section{a) Caracterização macroscópica (ensaio de líquido penetrante)}

De uma forma geral, os corpos-de-prova $\phi 30$ apresentaram maior resistência à propagação das trincas radial e circunferencial do que os corpos-de-prova $\phi 25$. De outro lado, os corpos-de-prova $\phi 30$ apresentaram maior quantidade de trincas macroscópicas (excluindo a radial e a circunferencial) do que os corpos-de-prova $\phi 25$.

A figura 79 apresenta um quadro geral do comportamento dessas ligas. 


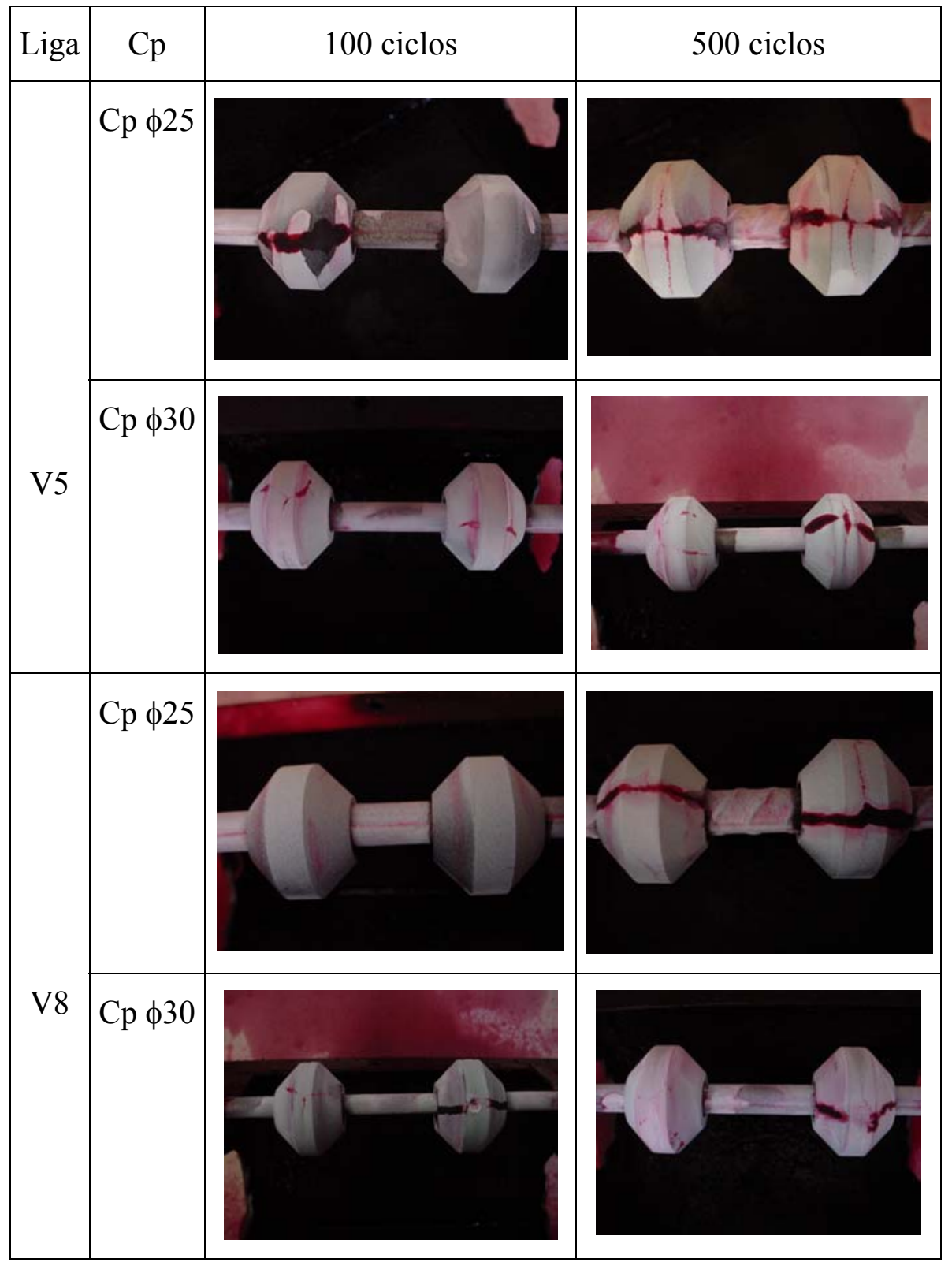

Figura 79 - Caracterização macroscópica das trincas dos corpos-de-prova da terceira série de experimentos. 


\section{b) Caracterização microscópica}

\section{Oxidação superficial}

Com relação à oxidação superficial, valem as mesmas considerações tecidas para a primeira série de experimentos.

\section{$\underline{\text { Densidade de trincas }}$}

A tabela 20 mostra os valores de densidade de trincas (trincas $/ \mathrm{mm}$ ) dos corpos-de-prova da terceira série de experimentos ensaiados a 100 ciclos. Os intervalos de variação foram determinados para um nível de confiança de 95\%.

Tabela 20 - Densidade de trincas dos corpos-de-prova da terceira série de experimentos ensaiados a 100 ciclos

\begin{tabular}{|c|c|c|c|c|}
\hline \multirow{2}{*}{ Liga } & \multicolumn{3}{|c|}{ Dt (trincas/mm) } \\
\cline { 2 - 5 } & \multicolumn{2}{|c|}{ Cp $\phi 25$} & \multicolumn{2}{c|}{ Cp $\phi 30$} \\
\cline { 2 - 5 } & Cp 1 & Cp 2 & Cp 1 & Cp 2 \\
\hline V5 & 14,7 & 20 & 21 & 18,8 \\
\hline V8 & 20 & 21,2 & 21,1 & 35,4 \\
\hline
\end{tabular}

A figura 80 apresenta o valor médio de densidade de trincas para ambas as ligas e para os dois tamanhos de corpo-de-prova no ensaio de 100 ciclos. 


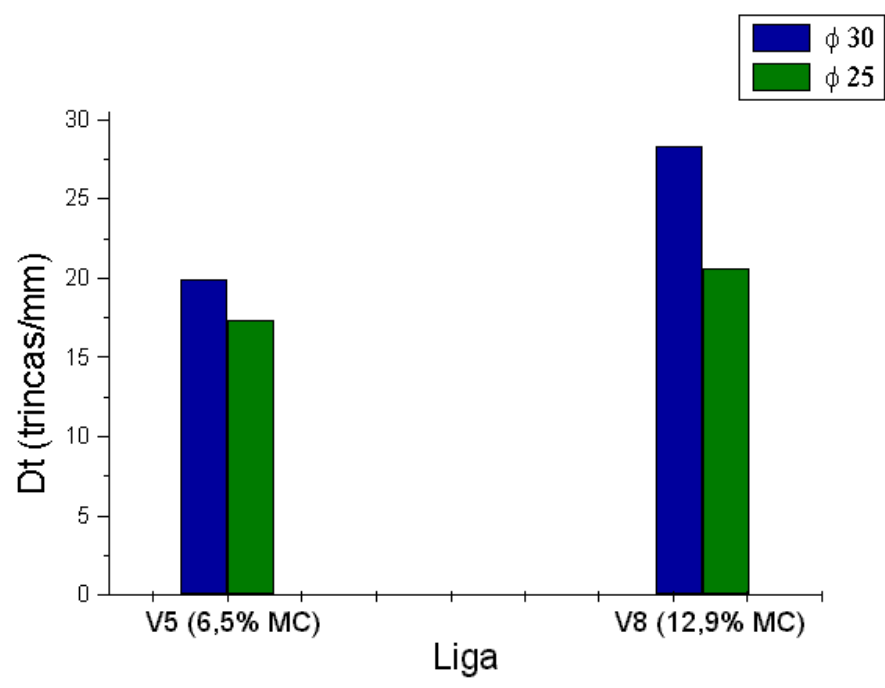

Figura 80 - Densidade de trincas para as ligas V5 e V8 e para os dois tamanhos de corpo-de-prova no ensaio de 100 ciclos.

A figura mostra que a densidade de trincas é maior no Cp $\phi 30$ e, ainda, para esses corpos-de-prova, a densidade é maior para a liga V8 $(12,9 \%$ de carboneto eutético MC).

As características microestruturais são as mesmas observadas na primeira série.

\section{Profundidade máxima de trinca}

A tabela 21 mostra os valores de profundidade máxima de trinca dos corposde-prova da terceira série de experimentos ensaiados a 100 e 500 ciclos. 
Tabela 21 - Profundidade máxima de trinca dos corpos-de-prova da terceira série de experimentos

\begin{tabular}{|c|c|c|c|c|}
\hline \multirow{2}{*}{ Corpo-de-prova } & \multicolumn{4}{|c|}{ Pmáx $(\mu \mathrm{m})$} \\
\cline { 2 - 5 } & \multicolumn{2}{|c|}{$\mathrm{Cp} \phi 25$} & \multicolumn{2}{c|}{$\mathrm{Cp} \phi 30$} \\
\cline { 2 - 5 } & $\mathrm{Cp} 1$ & $\mathrm{Cp} 2$ & $\mathrm{Cp} 1$ & $\mathrm{Cp} \mathrm{2}$ \\
\hline $\mathrm{V} 5 / 100$ & 143 & 94 & 4150 & 5000 \\
\hline $\mathrm{V} 5 / 500$ & 127 & n.d. & 4450 & 5360 \\
\hline $\mathrm{V} 8 / 100$ & 66 & 93 & 3280 & 3120 \\
\hline $\mathrm{V} 8 / 500$ & 189 & 290 & 5040 & 5000 \\
\hline
\end{tabular}

n.d.: não-determinada

A figura 81 apresenta o valor médio de profundidade máxima de trinca para ambas as ligas e para os dois tamanhos de corpo-de-prova ensaiados a 100 e 500 ciclos.

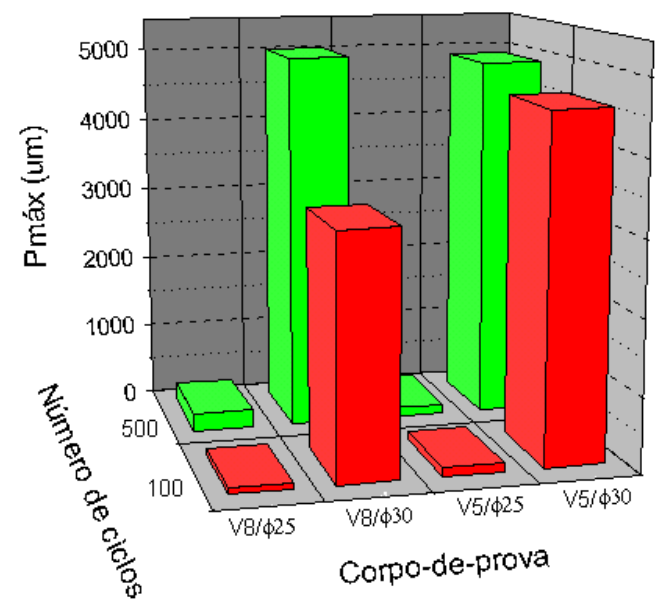

Figura 81 - Profundidade máxima de trinca para as ligas V5 e V8 e para os dois tamanhos de corpo-de-prova nos ensaios de 100 e 500 ciclos.

A figura mostra que a profundidade máxima de trinca é maior no $\mathrm{Cp} \phi 30 \mathrm{e}$, ainda, para esses corpos-de-prova, a profundidade máxima de trinca no ensaio de 100 ciclos é maior para a liga V5 (6,5\% de carboneto eutético MC). 
O caminho de propagação na liga V5, que possui dendritas em sua microestrutura, é interdendrítico (figura 82).

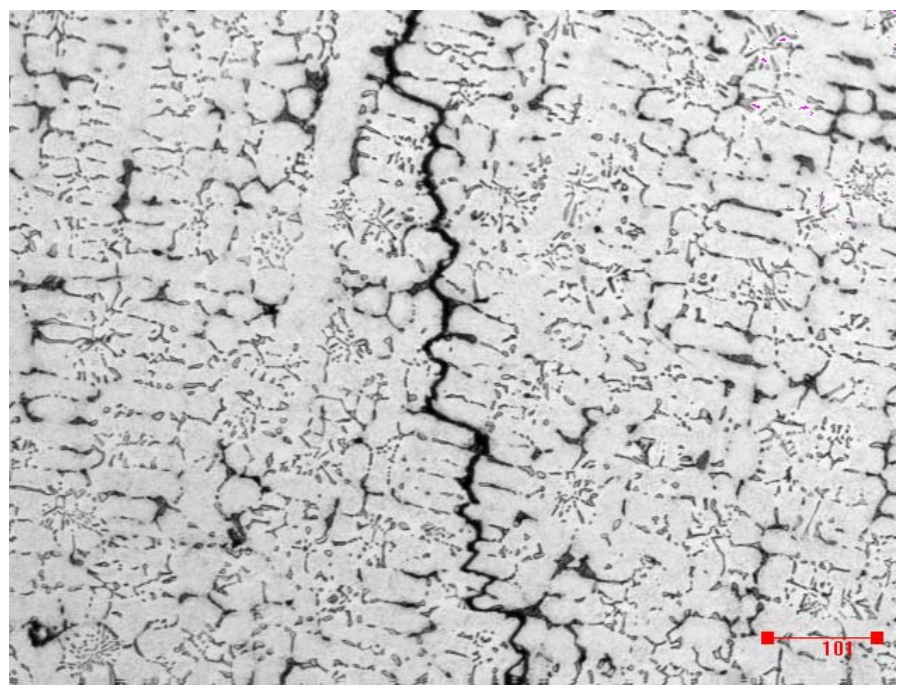

Figura 82 - Seção transversal do corpo-de-prova V5/450/500, mostrando a propagação da trinca pela região interdendrítica. Ataque: Eletrolítico+Grosbeck.

A propagação das trincas ocorre predominantemente pela interface carboneto/matriz e, em alguns raros casos pelo próprio carboneto (atravessando-o). A figuras 83 mostra esses tipos de propagação.

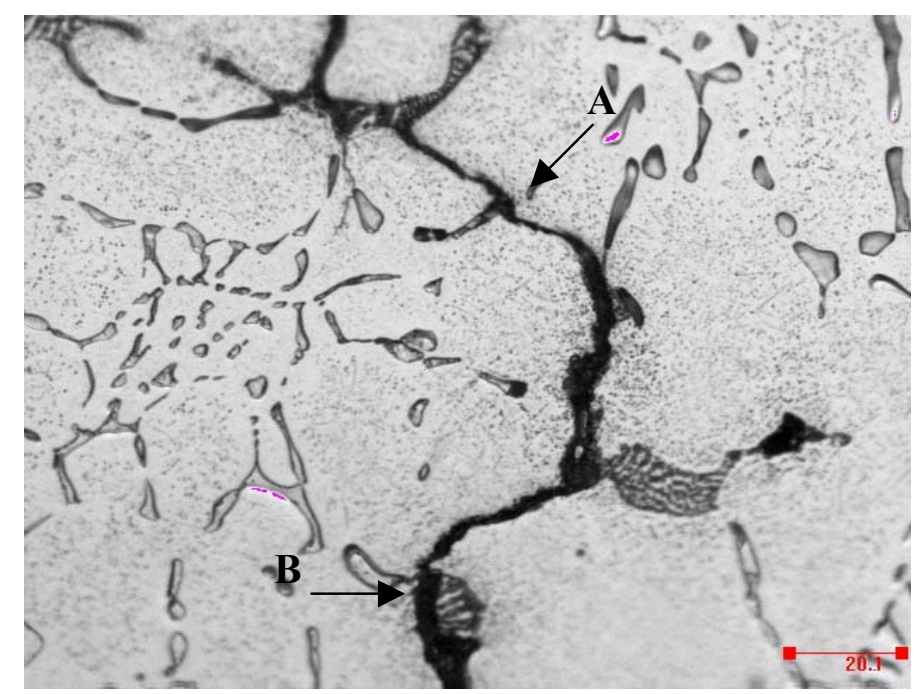

Figura 83 - Seção transversal do corpo-de-prova V5/450/100, mostrando a propagação da trinca pela interface: $\mathbf{A}$ - carboneto $\mathrm{MC} /$ matriz e $\mathbf{B}$ - carboneto M2C/matriz. Ataque: Eletrolítico+Grosbeck. 
$\mathrm{Na}$ liga $\mathrm{V} 8$, quando a ponta da trinca encontra um carboneto, a propagação ocorre predominantemente pela interface carboneto/matriz, como mostram as figuras 84 e 85.

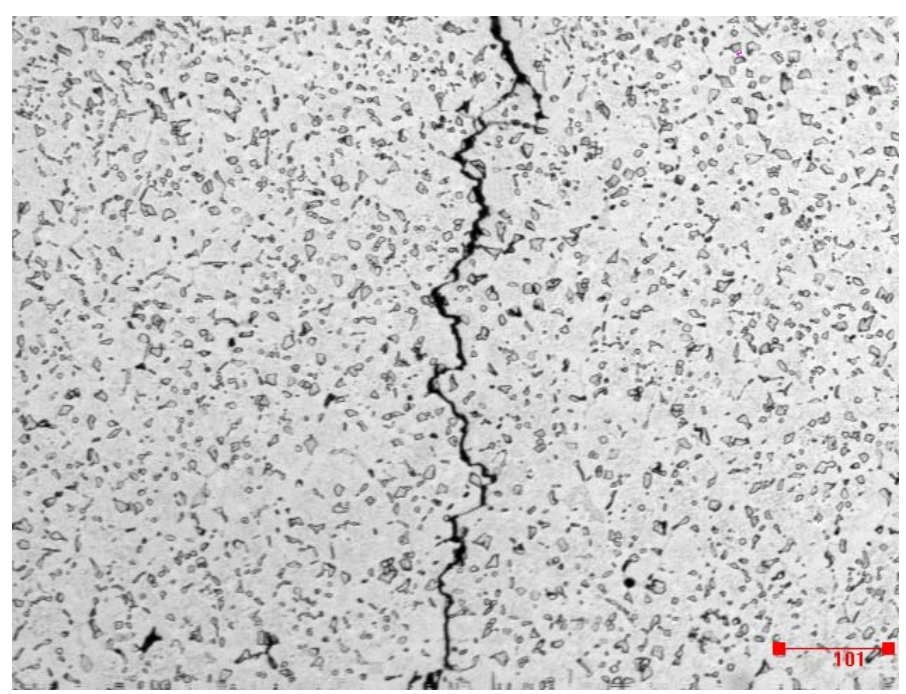

Figura 84 - Seção transversal do corpo-de-prova da liga V8/450/500, mostrando a propagação da trinca pelos carbonetos. Ataque: Eletrolítico+Grosbeck.

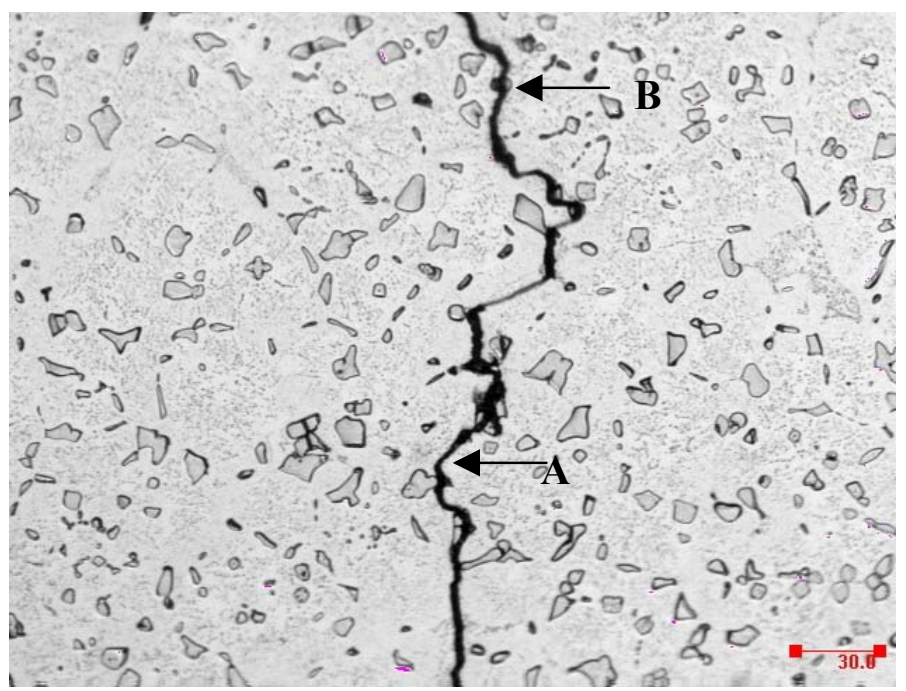

Figura 85 - Seção transversal do corpo-de-prova da liga V8/450/500, mostrando a propagação da trinca: A - pela interface carboneto $\mathrm{MC} /$ matriz, $\mathbf{B}$ - pelo carboneto MC. Ataque: Eletrolítico.

A tabela 22 apresenta os valores de taxa de propagação da maior trinca dos corpos-de-prova da terceira série de experimentos. 
Tabela 22 - Taxa de propagação da maior trinca dos corpos-de-prova da terceira série de experimentos

\begin{tabular}{|c|c|c|c|c|}
\hline \multirow{2}{*}{ Liga } & \multicolumn{4}{|c|}{ Taxa de propagação da maior trinca $(\mu \mathrm{m} /$ ciclo) } \\
\cline { 2 - 5 } & \multicolumn{2}{|c|}{$\operatorname{Cp} \phi 25$} & \multicolumn{2}{c|}{$\mathrm{Cp} \phi 30$} \\
\cline { 2 - 5 } & 100 ciclos & 500 ciclos & 100 ciclos & 500 ciclos \\
\hline \multirow{2}{*}{ V5 } & 1,4 & 0,3 & 41,5 & 8,9 \\
\cline { 2 - 5 } & 0,9 & n.d. & 50,0 & 10,7 \\
\hline \multirow{2}{*}{ V8 } & 0,7 & 0,4 & 32,8 & 10,1 \\
\cline { 2 - 5 } & 0,9 & 0,6 & 31,2 & 10 \\
\hline
\end{tabular}

n.d.: não-determinada

A figura 86 mostra o valor médio da taxa de propagação da maior trinca para ambas as ligas e para os dois tamanhos de corpo-de-prova ensaiados a 100 e 500 ciclos. Os resultados apresentados nessas curvas são relativos à média aritmética entre os dois corpos-de-prova ensaiados.

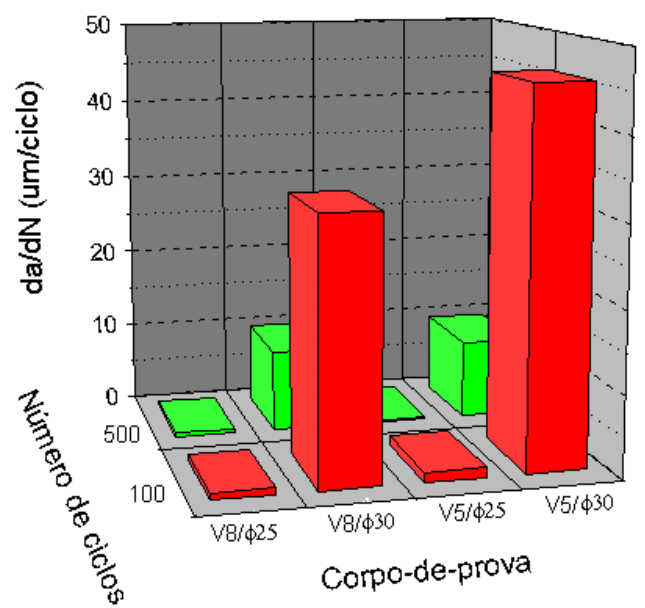

Figura 86 - Taxa de propagação da maior trinca para as ligas V5 e V8 e para os dois tamanhos de corpo-de-prova nos ensaios de 100 e 500 ciclos.

As taxas de propagação de trinca são maiores nos $\mathrm{Cp} \phi 30$ e, ainda, para esses corpos-de-prova, a taxa de propagação de trinca no ensaio de 100 ciclos é maior para a liga V5 (6,5\% de carboneto eutético MC). 


\section{c) Microdureza da matriz}

Em virtude dos resultados apresentados para a microdureza da matriz dos corpos-de-prova da primeira série de experimentos, que não indicaram diminuição de dureza nos corpos-de-prova com dureza nominal inicial de $450 \mathrm{HV}$, independentemente do número de ciclos, as medições de microdureza da matriz dessas ligas após o ensaio de fadiga térmica não foram realizadas. 


\section{DISCUSSÃO}

Inicialmente a discussão dos resultados será conduzida separadamente para cada série de experimentos. Ao final, será produzida uma síntese.

Entende-se que o parâmetro "densidade de trincas", obtido nos ensaios de 100 ciclos, relaciona-se diretamente com a taxa de nucleação das trincas. De outro lado, entende-se que o comportamento dos parâmetros "profundidade máxima de trinca" e "taxa de propagação da maior trinca" frente às variáveis estudadas, obtidos nos ensaios de 100 e 500 ciclos, reflitam o comportamento do processo de propagação das trincas frente às mesmas variáveis.

\subsection{Primeira série de experimentos}

Os resultados da figura 52 são compatíveis com o mecanismo clássico de nucleação de trincas por fadiga, segundo o qual esta resulta de deformação plástica microscópica localizada induzida pela presença de concentradores de tensão $9,10,15,16,17,19$.

De uma forma geral, o aumento da fração volumétrica de carbonetos eutéticos MC, que atuam como concentradores de tensão, promove o aumento da taxa de nucleação (aumento da densidade de trincas). A posição relativa das ligas V5 e V6,5 representa uma exceção a este comportamento geral e será tratada mais adiante.

De outro lado, o aumento da resistência mecânica da matriz promove a diminuição da taxa de nucleação, pois dificulta a ocorrência de deformação plástica localizada. O resultado do corpo-de-prova V8/550 reforça essa influência da resistência da matriz. Embora a dureza da matriz dos corpos-de-prova X/650 tenha, após 100 ciclos de ensaio, diminuído na região até $200 \mu \mathrm{m}$ abaixo da superfície (região de propagação durante os 100 ciclos), ela ainda permaneceu maior do que a dos corpos-de-prova X/450 na mesma região (tabela 13). Desta forma, é efetiva a influência da resistência da matriz sobre a densidade de trincas.

Além disso, fatores geométricos como descontinuidades superficiais também atuaram como concentradores de tensão, fato confirmado pelos resultados das ligas AM, que, mesmo sem possuir carbonetos eutéticos em sua microestrutura, apresentaram nucleação de trincas (figuras 53 e 54). Além das ligas AM, as ligas 
com carbonetos eutéticos também apresentaram trincas nucleadas na matriz livre, sem associação com carbonetos eutéticos, como mostra a figura 87.

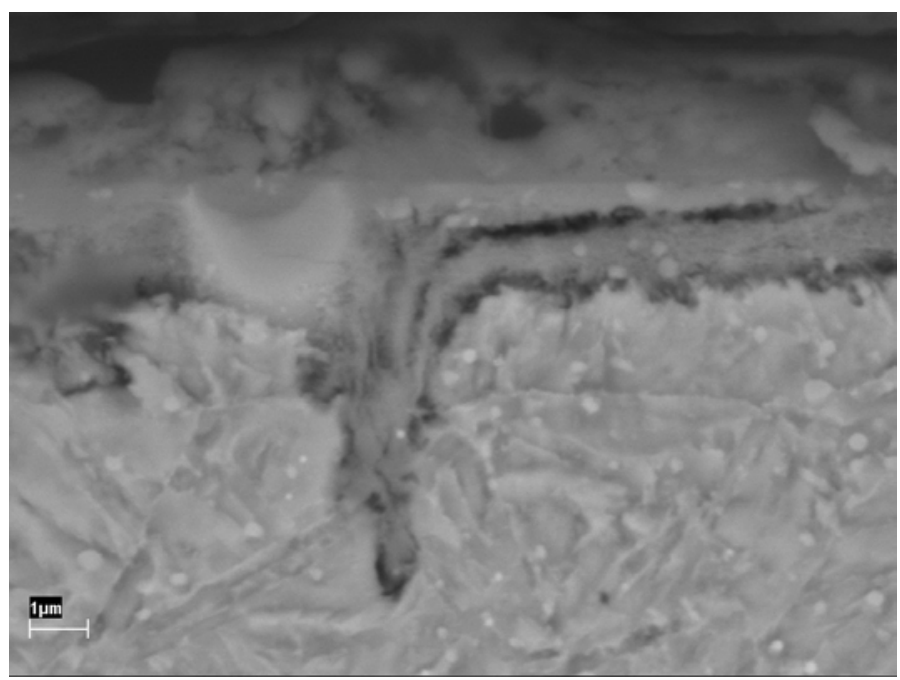

Figura 87 - Seção transversal do corpo-de-prova V5/450/100, mostrando uma trinca nucleada na matriz. MEV - elétrons secundários.

$\mathrm{O}$ efeito dos carbonetos eutéticos $\mathrm{MC}$ como concentradores de tensão foi confirmado por resultados obtidos com a aplicação combinada dos programas $\mathrm{PPM}_{2} \mathrm{OOF}^{58}$ e $\mathrm{ABAQUS}^{59}$, de tal forma a simular o ciclo térmico sofrido pelo corpo-de-prova e obter a resultante distribuição de tensões associadas à microestrutura na sua superfície. A figura 88 mostra o resultado obtido para a liga V6,5. 


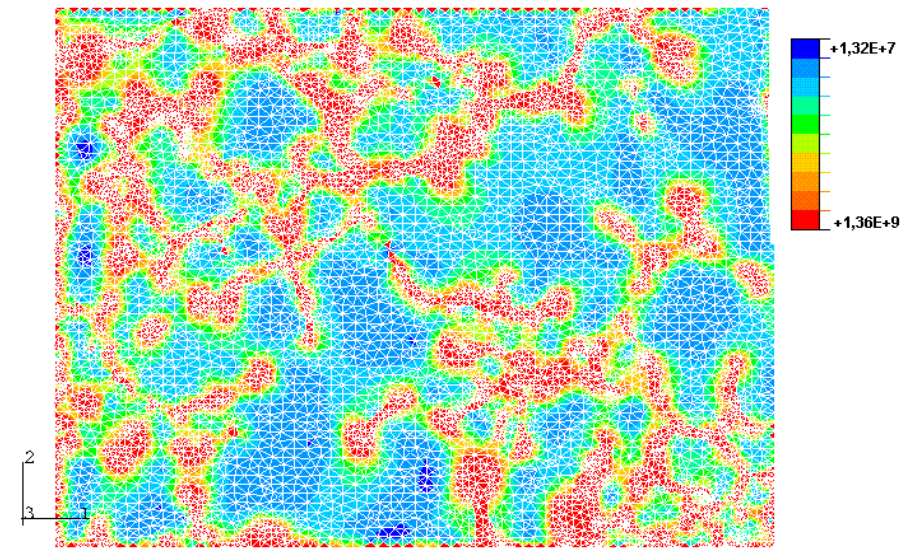

(a)

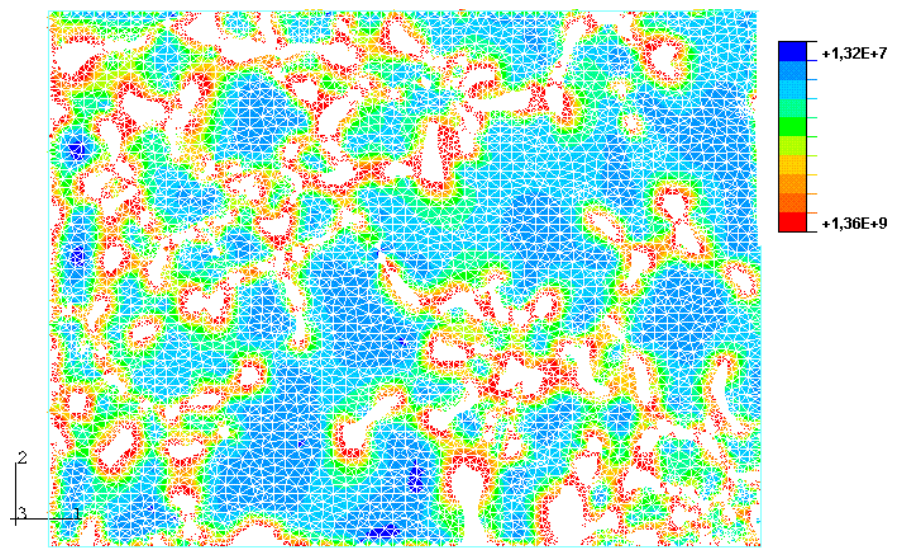

(b)

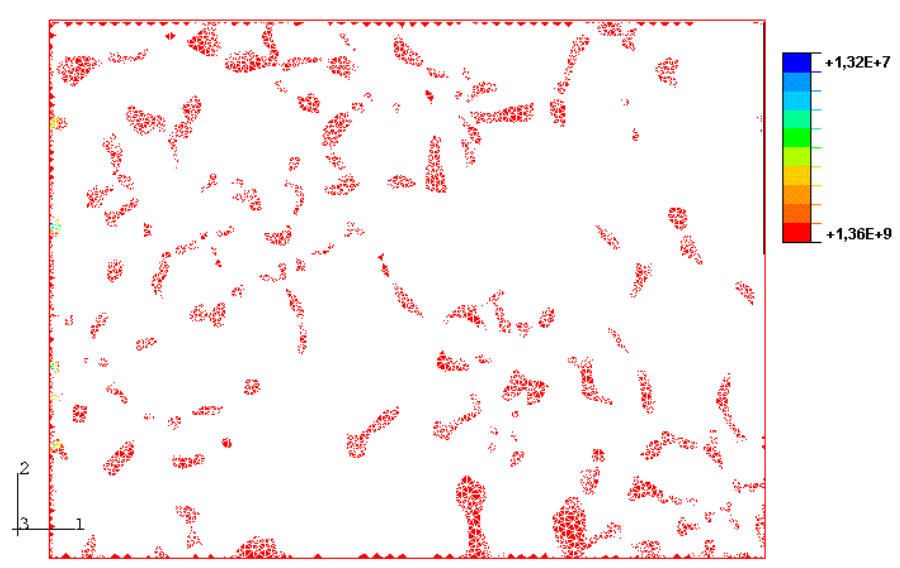

(c)

Figura 88 - Distribuição de tensões na microestrutura da liga V6,5 pelo critério Von Mises. A superfície do corpo-de-prova é representada pela lateral direita da figura e a espessura apresentada é de $160 \mu \mathrm{m}$.(a) distribuição de tensões geral; (b) distribuição de tensões na matriz e (c) distribuição de tensões nos carbonetos. 
Observa-se que a concentração de microtensões ocorre no próprio carboneto e na interface carboneto/matriz, ambas decorrentes da diferença entre os valores de coeficiente de expansão térmica e de módulo de elasticidade do carboneto $\mathrm{MC}$ e da matriz. De fato, segundo dados da literatura ${ }^{60,61}$, estes valores são de $7,3 * 10^{-6} \mathrm{~m} /{ }^{\circ} \mathrm{C}$ e $430 \mathrm{GPa}$ para o carboneto $\mathrm{MC}$ e $11^{*} 10^{-6} \mathrm{~m} /{ }^{\circ} \mathrm{C}$ e $210 \mathrm{GPa}$ para o aço $\mathrm{H} 13$, cuja composição química é semelhante à da matriz das ligas da primeira série de experimentos. Resultado semelhante foi obtido por Broeckmann e Pyazalla-Schieck estudando fratura das partículas duras de compósitos durante o resfriamento após tratamento térmico ${ }^{62}$.

A figura 62 mostra que as taxas de propagação no ensaio de 100 ciclos são significativamente maiores do que as taxas de propagação no ensaio de 500 ciclos, exceto no caso da liga AM, para a qual são semelhantes. Esta diferença é característica do processo de fadiga térmica, pois a intensidade dos campos tensãodeformação-temperatura num corpo sujeito a fadiga térmica decresce com o aumento da distância em relação à superfície do corpo $^{63}$. Dessa forma, a força motora para propagar uma trinca de fadiga térmica diminui à medida que a trinca propaga e sua ponta se afasta da superfície.

Além disto, o efeito da microestrutura sobre a taxa de propagação é menor no ensaio de 500 ciclos do que no ensaio de 100 ciclos (figura 62b).

É possível, então, raciocinar em termos de regimes distintos de propagação, de acordo com o tempo de ensaio. No ensaio de 100 ciclos, dadas as tensões elevadas e, conseqüentemente, os elevados fatores de intensidade de tensões associados às trincas nucleadas, há um regime caracterizado pela propagação instável controlada pelo valor de $\mathrm{K}_{\mathrm{IC}}$ do material (estágio III da curva da/dN x $\Delta \mathrm{K}$ ) ${ }^{25,64}$. Desta forma, quanto menor o valor de $\mathrm{K}_{\mathrm{IC}}$, maior a taxa de propagação. A literatura mostra que, para uma dada resistência mecânica do material, $\mathrm{K}_{\mathrm{IC}} \propto \mathrm{X}_{0}^{1 / 2}$, em que $\mathrm{X}_{0}$ é denominada "distância característica" 65 . No caso de microestruturas com partículas duras dispersas na matriz, $\mathrm{X}_{0}$ é igual à distância livre média entre as partículas. Confrontando as figuras 48 e 62a, observa-se que a liga V6,5, que possui o menor valor de Dm, apresenta o maior valor de da/dN. 
Porém, a liga V5, com maior valor de Dm do que o da liga V8, apresenta maior valor de da/dN. Esta aparente contradição pode ser explicada pela distribuição de carbonetos. A distribuição localizada de carbonetos exerce uma influência significativa sobre a propagação da trinca; na verdade, o valor de Dm significativo é aquele referente à região de maior continuidade da trinca, e não o valor médio representativo da microestrutura como um todo, pois a propagação ocorre em escala microscópica.

Vale lembrar que nas ligas conformadas mecanicamente, em que há formação de "estrias" de carbonetos, o efeito é semelhante, ou seja, a resistência à propagação da trinca diminui com a presença de carbonetos alinhados ${ }^{66}$.

A figura 89 mostra, por exemplo, a continuidade dos carbonetos MC na região interdendrítica da liga V5 (que se reflete num pequeno valor local de distância entre carbonetos).

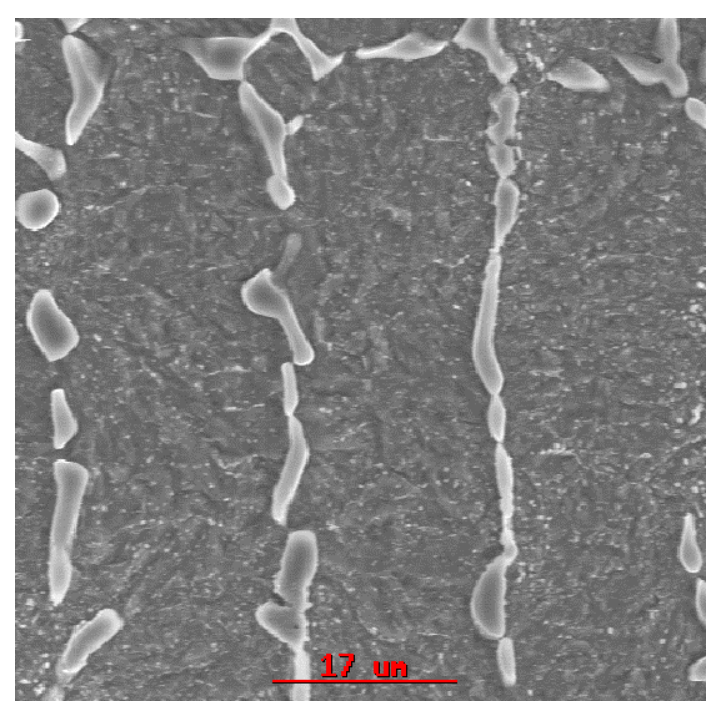

Figura 89 - Microestrutura da liga V5, mostrando a continuidade de carbonetos MC na região interdendrítica. $\mathrm{MEV}$ - elétrons secundários.

O efeito combinado de Dm e C (figura 48) pode ser expresso por um parâmetro dado pela relação C/Dm. A tabela 23 mostra esse parâmetro. 
Tabela 23 - Parâmetro C/Dm do carboneto eutético para as ligas da primeira série de experimentos

\begin{tabular}{|l|l|l|l|}
\hline C/Dm & V5 & V6,5 & V8 \\
\cline { 2 - 4 }$(\mu \mathrm{m})$ & 1,07 & 1,19 & 0,86 \\
\hline
\end{tabular}

Dessa forma, quanto maior a relação $\mathrm{C} / \mathrm{Dm}$, maior a taxa de propagação.

Há uma interpretação adicional para esta correlação entre microestrutura e da/dN, que é o tamanho da zona plástica à frente da trinca. A tensão alta no ensaio de 100 ciclos implica alto fator de intensidade de tensão $(K)$ e grande tamanho da zona plástica, eventualmente maior que a distância característica (figura 90). Se o livre caminho médio entre os carbonetos é pequeno o suficiente para permitir que haja carbonetos dentro da zona plástica (ligas V5 e V6,5), o valor de $\mathrm{K}_{\mathrm{IC}}$ do material é baixo (figura 90a). De outro lado, se o livre caminho médio entre os carbonetos é grande (liga V8), o valor de $\mathrm{K}_{\mathrm{IC}}$ do material é elevado (figura 90b) ${ }^{67}$.

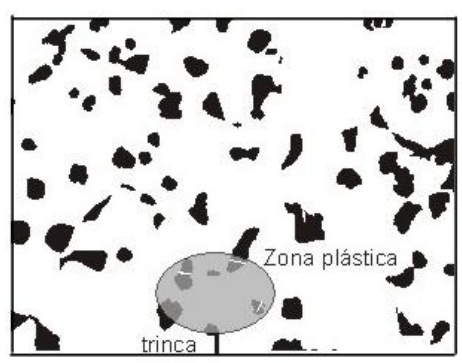

(a)

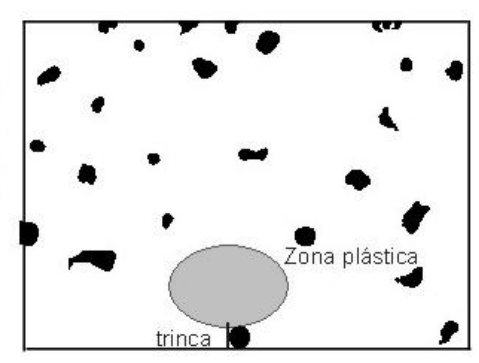

(b)

Figura 90 - Representação esquemática da distribuição de carbonetos e da zona plástica na ponta da trinca (adaptada da referência 67).

Dessa forma, pode-se apresentar um modo de propagação da trinca:

1) Nucleação da trinca em concentradores de tensão superficiais e formação de trincas em carbonetos eutéticos subsuperficiais (decoesão da interface carboneto/matriz e/ou clivagem do carboneto); 
2) Propagação da trinca principal em direção ao carboneto subsuperficial trincado e formação de novas trincas em outros carbonetos.

A figura 91 mostra uma representação esquemática do modo de propagação proposto. A trinca cuja zona plástica não "contém" carbonetos apresenta menor taxa de propagação.
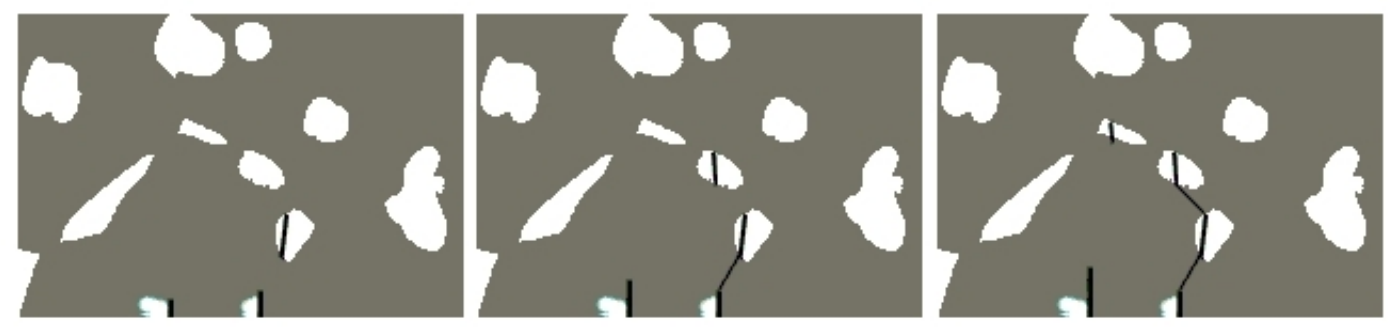

Figura 91 - Representação esquemática do modo de propagação de trinca.

A figura 92 mostra uma evidência experimental da proposição acima, em que se observa um carboneto trincado à frente de uma trinca principal.

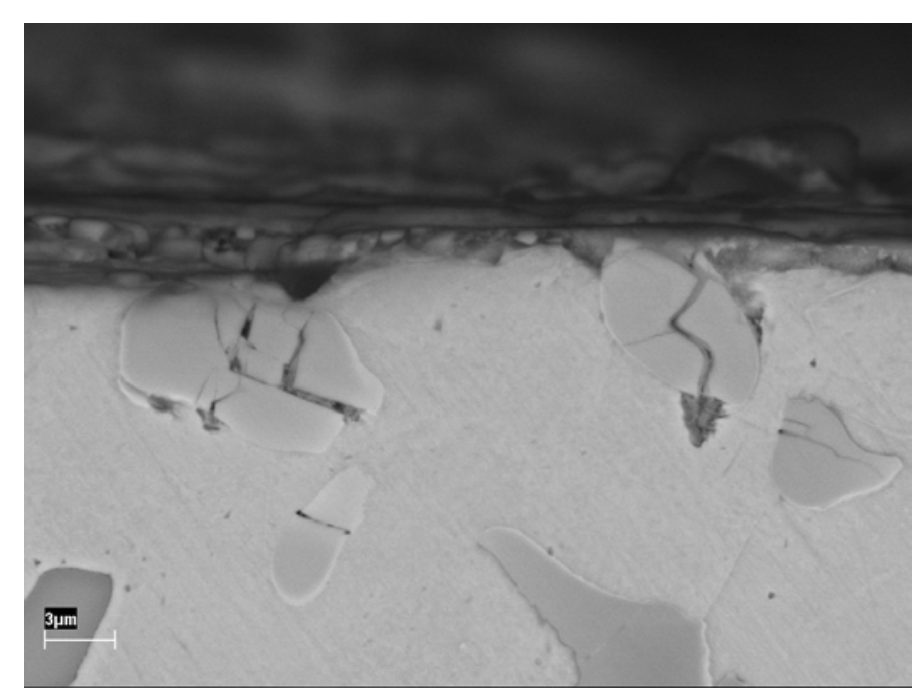

Figura 92 - Seção transversal do corpo-de-prova V8/450/100, mostrando um carboneto trincado ao lado de uma trinca principal. MEV - elétrons retro-espalhados.

Os diagramas da figura 88 mostram, adicionalmente, que a distribuição de microtensões na microestrutura das ligas estudadas também sofre influência da 
distribuição dos carbonetos eutéticos $\mathrm{MC}$, pois quando a distância entre os carbonetos eutéticos é pequena, forma-se um “caminho" contínuo de tensão elevada, favorável à propagação de trincas.

No ensaio de 500 ciclos, devido às baixas tensões vigentes a distâncias da superfície superiores a $190 \mu \mathrm{m}$ (máxima profundidade de trinca após 100 ciclos), o regime é de propagação controlada pela magnitude da máxima tensão alternada (estágio II da curva da/dN x $\Delta \mathrm{K}$ ). Neste caso, o tamanho da zona plástica à frente da trinca é pequeno e sempre inferior à "distância característica", fazendo com que a influência da distribuição dos carbonetos eutéticos MC sobre a taxa de propagação não seja significativa (figura 93).

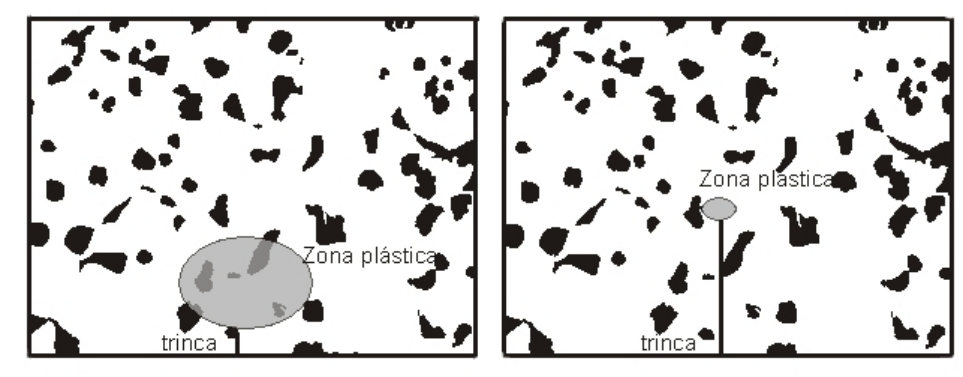

(a)

(b)

Figura 93 - Representação esquemática do tamanho da zona plástica na ponta da trinca. (a) região próxima à superfície do corpo-de-prova (ensaio de 100 ciclos); b) região distante da superfície do corpo-de-prova (ensaio de 500 ciclos).

O fato de o valor de da/dN da liga $\mathrm{AM}$ ser baixo e não se alterar significativamente com o tempo de ensaio demonstra a importância da presença dos carbonetos eutéticos MC sobre a propagação das trincas e corrobora os argumentos anteriores (pode-se pensar que, nesta liga, a distância livre média entre as partículas de MC seja “infinita”).

Não se observa uma influência clara da dureza da matriz sobre o valor de da/dN das ligas V5 e V6,5. A liga V8 com dureza inicial de $550 \mathrm{HV}$, ao contrário das demais ligas, manteve esse valor de dureza mesmo após o ensaio de 500 ciclos, indicando que o aumento da dureza da matriz promove uma diminuição de da/dN. 
A figura 94 mostra uma síntese do comportamento sob fadiga térmica das ligas da primeira série de experimentos nos ensaios de 100 ciclos, que, como mostram os resultados de $\mathrm{Dt}$ e da/dN discutidos anteriormente, é determinante no comportamento geral em ensaios mais longos.

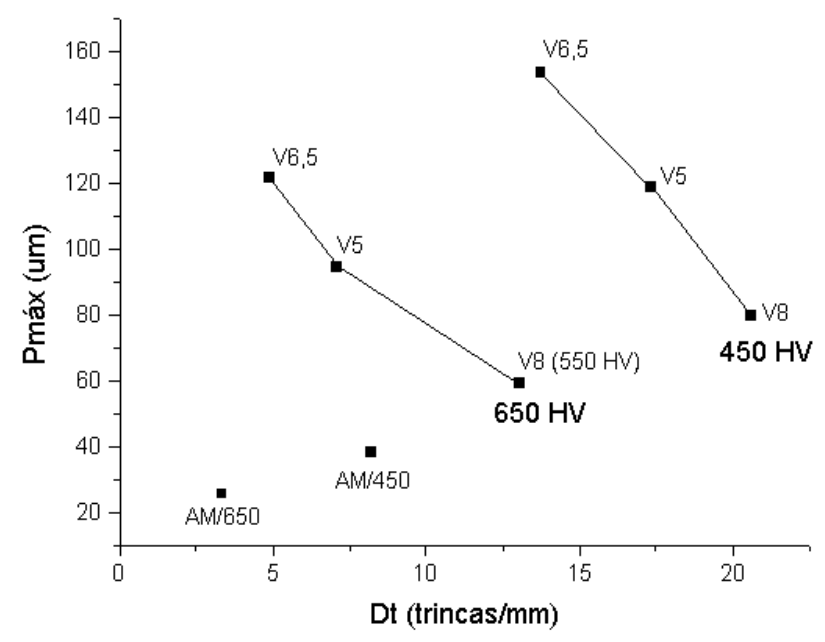

Figura 94 - Correlação entre profundidade máxima de trinca e densidade de trincas para os corpos-de-prova ensaiados a 100 ciclos.

Observa-se que há uma relação entre profundidade e densidade de trincas; na liga que apresentou uma elevada taxa de nucleação (liga V8), as trincas propagaramse com menor intensidade do que na liga que apresentou baixa taxa de nucleação (liga V6,5), ou seja, a cinética de crescimento das trincas é tanto menor quanto maior sua densidade (isto é, quanto maior a cinética de nucleação). Esse resultado é semelhante ao obtido por Wisniewski et al. estudando a influência de carbonetos sobre a fadiga térmica de materiais para cilindros de laminação a quente ${ }^{46}$.

Enfim, é possível afirmar que nucleação e propagação de trincas são fenômenos que competem entre si pela dissipação da energia acumulada no corpo; a prevalência de um ou outro depende da distribuição de carbonetos eutéticos MC na microestrutura.

Além disso, a figura mostra que o efeito da dureza da matriz é maior sobre a densidade de trincas do que sobre a profundidade. 
É possível estabelecer uma relação entre as figuras 50 e 94; a liga V6,5, que apresentou a maior intensidade de trincas macroscópicas radial e circunferencial (figura 50), também apresentou a maior taxa de propagação de trincas microscópicas (figura 94). No outro extremo está a liga AM: ausência de trincas macroscópicas radial e circunferencial e menor taxa de propagação de trincas microscópicas.

\subsection{Segunda série}

A figura 71 indica um resultado contrário à argumentação desenvolvida na primeira série de experimentos, pois a densidade de trincas diminuiu com o aumento da fração volumétrica de carbonetos $\mathrm{M}_{2} \mathrm{C}$ (concentradores de tensão).

Entretanto, ao expressar a densidade de trincas em função da variação de carbonetos eutéticos $\mathrm{MC}$, que é o carboneto com maior fração volumétrica presente na microestrutura (tabela 14), o resultado é semelhante ao obtido para as ligas da primeira série, como mostra a figura 95.

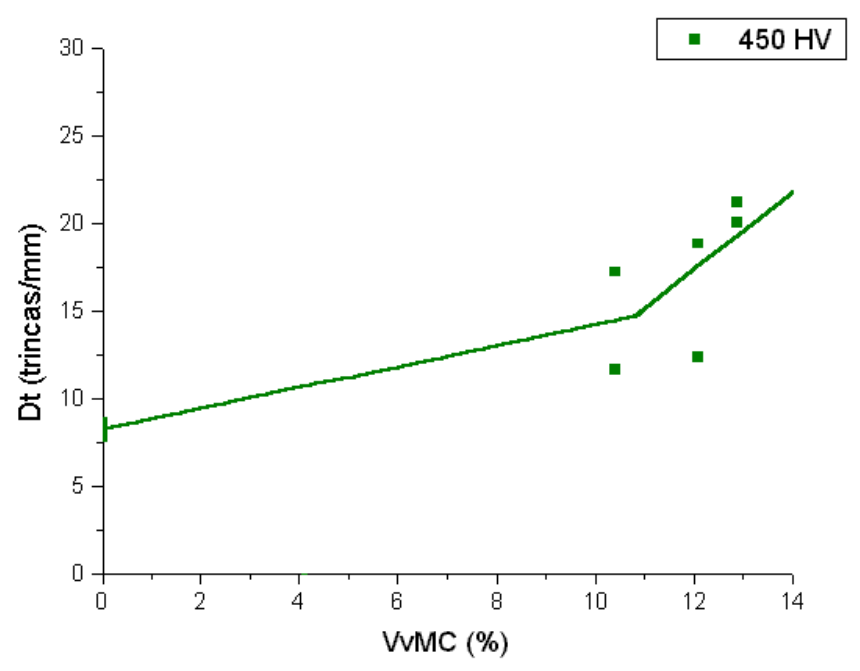

Figura 95 - Densidade de trincas em função da fração volumétrica de carboneto eutético MC para o ensaio de 100 ciclos.

Dessa forma, valem as mesmas considerações tecidas para a primeira série de experimentos, ou seja, o aumento da fração volumétrica de carbonetos eutéticos MC (concentradores de tensão) promove um aumento da taxa de nucleação. 
A figura 78 mostra que a taxa de propagação da maior trinca não sofre uma influência clara da variação de carbonetos $\mathrm{M}_{2} \mathrm{C}$. Ao analisar a variação da taxa de propagação em função da variação do carboneto $\mathrm{MC}$, observa-se comportamento similar, em que pese a variação indicada pela linha de tendência (figura 96).

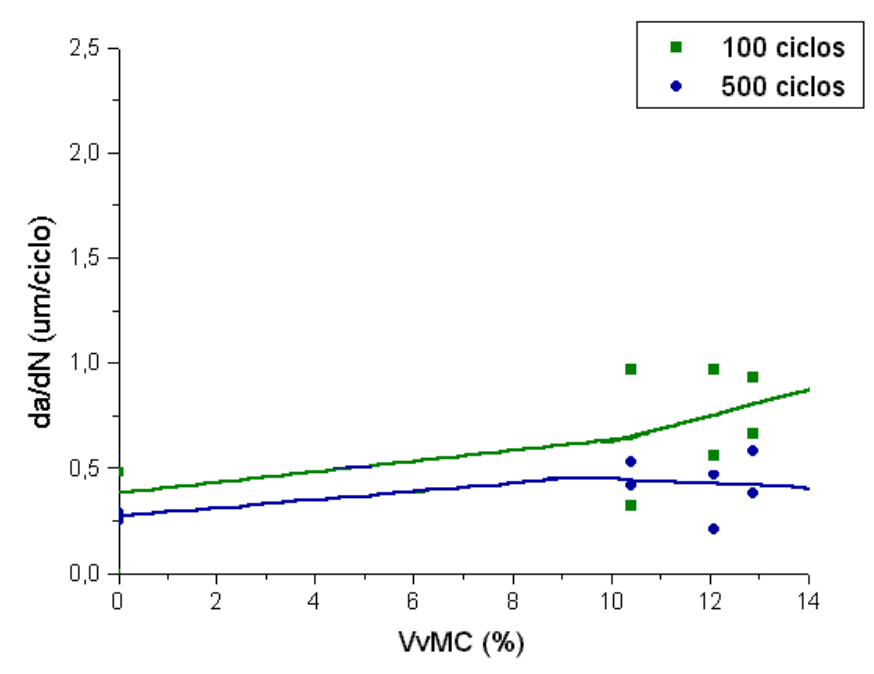

Figura 96 - Taxa de propagação da maior trinca em função da fração volumétrica de carboneto eutético MC.

Novamente, há uma aparente contradição deste comportamento quando confrontado com os valores de Dm (figura 69). Pode-se utilizar o mesmo raciocínio de continuidade de carbonetos. A tabela 24 mostra o parâmetro C/Dm do carboneto eutético para essas ligas.

Tabela 24 - Parâmetro C/Dm do carboneto eutético para as ligas da segunda série de experimentos

\begin{tabular}{|c|c|c|c|}
\hline C/Dm & M2 & M3,5 & M5 \\
\cline { 2 - 4 }$(\mu \mathrm{m})$ & 0,86 & 0,70 & 0,84 \\
\hline
\end{tabular}

Os valores de da/dN não são compatíveis com a relação $\mathrm{C} / \mathrm{Dm}$; entretanto, confrontando o valor de C/Dm com a figura 70, observa-se que a liga M3,5, que possui a menor relação $\mathrm{C} / \mathrm{Dm}$ apresentou a menor intensidade de trincas macroscópicas (figura 70). 


\subsection{Síntese}

A figura 97 mostra uma síntese do comportamento das ligas da primeira e segunda série de experimentos com dureza da matriz de $450 \mathrm{HV}$.

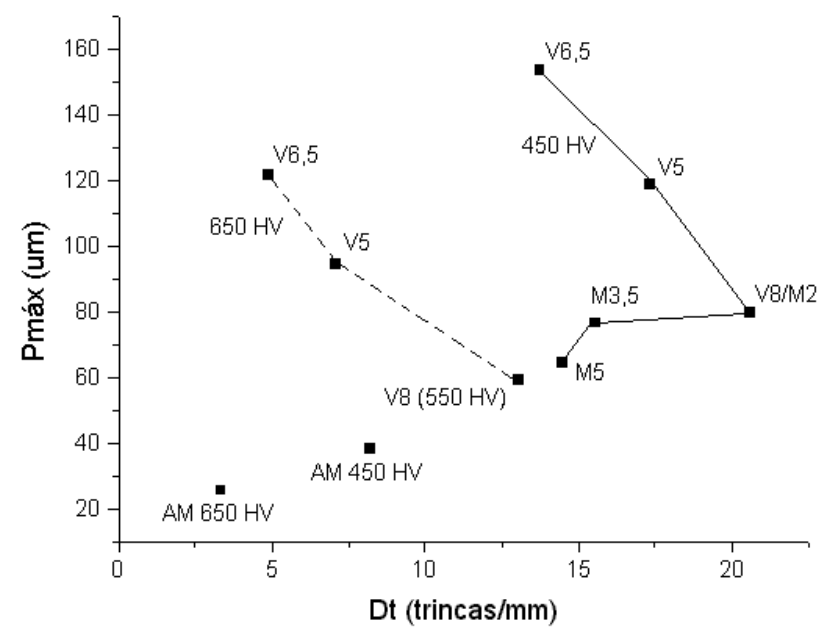

Figura 97 - Correlação entre densidade e profundidade de trinca para as ligas da primeira e segunda série com dureza da matriz de $450 \mathrm{HV}$ ensaiadas a 100 ciclos.

Nas ligas da primeira série, à medida que o teor de vanádio aumenta e, portanto, a fração de carboneto eutético MC aumenta, há uma alteração da distribuição de carbonetos eutéticos. Essa alteração leva a maior ou menor dificuldade de propagação de trinca. Então, de um lado, a fração de carbonetos aumenta, favorecendo a nucleação de trincas (aumenta a densidade de trincas); de outro, a distribuição de carbonetos da liga V8 dificulta a propagação de trincas.

Nas ligas da segunda série, o aumento do teor de Mo diminui a fração de carboneto eutético MC, prejudicando a taxa de nucleação (diminui a densidade de trincas). De outro lado, a distribuição dos carbonetos não sofre alteração, motivo pelo qual a propagação de trincas nas ligas M2, M3,5 e M5 é qualitativamente a mesma.

\subsection{Terceira série}

Os resultados da terceira série de experimentos comprovam as informações da literatura quanto ao efeito do tamanho do corpo-de-prova sobre a resistência à fadiga térmica. $\mathrm{O}$ aumento do tamanho do corpo-de-prova promove o aumento das 
taxas de nucleação de trincas e de propagação. Esse resultado se deve aos maiores gradientes térmicos desenvolvidos nos corpos-de-prova com maiores dimensões que promovem tensões mais elevadas.

Valem as mesmas considerações tecidas na primeira série de experimentos; no ensaio de 100 ciclos, dadas as tensões elevadas, a propagação é caracterizada pelo estágio III da curva da/dN x $\Delta \mathrm{K}){ }^{25,68}$ e aspectos microestruturais como distribuição de carboneto influenciam a propagação de trinca. No ensaio de 500 ciclos, as tensões envolvidas são menores e a propagação é caracterizada pelo estágio II da curva $\mathrm{da} / \mathrm{dN} \times \Delta \mathrm{K}$.

As diferenças entre as taxas de propagação dos corpos-de-prova $\phi 25$ e $\phi 30$ são compatíveis com a curva da/dN x $\Delta \mathrm{K}$. No ensaio de 100 ciclos (estágio III), em que as diferenças entre as taxas de propagação chegam a 40 vezes, pequenas alterações de $\Delta \mathrm{K}$ na curva da/dN x $\Delta \mathrm{K}$ levam a um aumento exponencial da taxa de propagação. No ensaio de 500 ciclos (estágio II), em que as diferenças entre as taxas de propagação são menores (20 a 30 vezes), as alterações de $\Delta \mathrm{K}$ levam a um aumento menor da taxa de propagação. 


\section{CONCLUSÕES}

O estudo da resistência à fadiga térmica de ferros fundidos brancos multicomponentes mostrou que:

1- A nucleação de trincas de fadiga térmica ocorre predominantemente na superfície do corpo-de-prova, induzidas por concentradores de tensão mecânicos e metalúrgicos. As trincas nucleiam na matriz (a rugosidade age como concentrador mecânico) e nos carbonetos (interface carboneto/matriz ou no próprio carboneto). A taxa de nucleação sofre influência da fração volumétrica de carboneto eutético (seu aumento promove aumento da taxa de nucleação) e da dureza da matriz (seu aumento promove diminuição da taxa de nucleação).

2- A propagação de trincas ocorre predominantemente pela interface carboneto/matriz ou através do carboneto. A taxa de propagação sofre influência da distribuição de carboneto eutético. Quanto maior a relação $\mathrm{C} / \mathrm{Dm}$, maior a taxa de propagação de trincas.

3- A taxa de propagação de trinca diminui com o aumento do tempo de ensaio, independentemente da fração volumétrica de carboneto eutético, da dureza da matriz e do tamanho do corpo-de-prova.

4- O regime de propagação durante os primeiros 100 ciclos é caracterizado pela propagação instável da trinca controlada pela tenacidade à fratura do material; de 100 a 500 ciclos, a propagação é controlada pela magnitude da tensão.

5- A taxa de propagação de trinca não sofre influência clara da dureza da matriz, independentemente da fração volumétrica de carbonetos eutéticos.

6- O aumento do tamanho do corpo-de-prova promove aumento das taxas de nucleação e propagação. Este resultado é atribuído ao aumento do gradiente térmico ao longo do corpo-de-prova com o aumento do seu diâmetro. 


\section{REFERÊNCIAS BIBLIOGRÁFICAS}

${ }^{1}$ BOCCALINI JR., M., SINATORA, A., MATSUBARA, Y. Overview: high speed steels for hot rolling mill rolls, In: SEMINÁRIO DE LAMINAÇÃO PROCESSOS E PRODUTOS LAMINADOS E REVESTIDOS, XXXVII, Curitiba-PR, 20-200 setembro 2000. Anais. São Paulo: ABM, 2000, p.587-596.

${ }^{2}$ RYU, J.H. et al. Evaluation of the finishing roll surface deterioration at hot strip mill. ISIJ International, v.32, n.11, p. 1221-3, 1992.

${ }^{3}$ SPUZIC, S. et al. Wear of hot rolling mill rolls: an overview. Wear, v.176, p. 26171, 1994.

${ }^{4}$ DIAS, A. Problème de l'endommagement des tables des cylindres de travail des trains à bandes à chaud. Importance de la fatigue thermique I. Revue de Métallurgie, p. 643-56, aug.-sept.1986.

${ }^{5}$ MAGNÉE, A.; GASPARD, C.; COUTSOURADIS, D. Analyse des sollicitations de cylindres de travail à chaud. Revue de Métallurgie, p. 35-52, jan. 1977.

${ }^{6}$ CHANG, DER-FORM. Thermal stresses in work rolls during the rolling of metal strip. Journal of Materials Processing Technology, v.94, p. 45-51, 1999.

${ }^{7}$ ERICKSON, L. C. ; HOGMARK, S. Analysis of banded hot rolling rolls. Wear, v.165, p. 231-235, 1993.

${ }^{8}$ DEBARBADILLO, J.J., TROZZI, C.J. Mechanism of banding in hot strip mill work rolls, Iron and Steel Engineer, p. 63-72, jan 1981.

9 HERTZBERG, R.W. Deformation and fracture mechanics of engineering materials. $4^{\mathrm{a}}$ ed. New York: John Wiley, 1995. 786p. 
${ }^{10}$ MALM, S., NORSTRÖN, L.A. Material-related model for thermal fatigue applied to tool steels in hot-work applications, Metal Science, p. 544-550, set 1979.

11 WERONSKI, A., HEJWOWSKI, T. Thermal Fatigue In: WERONSKI, A., HEJWOWSKI, T. Thermal Fatigue of Metals, New York: Marcel Dekker, 1991, p.108-134.

${ }^{12}$ PARK, J.H. et al. The effects of alloying elements on thermal fatigue and thermal shock resistance of the HSLA cast steels. ISIJ International, v.40, n.11, p.1164$1169,2000$.

${ }^{13}$ MANSON, S.S. Thermal Shock. In: MANSON, S.S. Thermal stress and lowcycle fatigue. New York: MaGraw-Hill, 1966, p.275-312.

${ }^{14}$ HASSELMAN, D.P.H., SINGH, J.P. Criteria for the Thermal Stress Failure of Brittle Structural Ceramics. In: HETNARSKI, R.B. Thermal Stresses I. New York: North-Holland, 1986, p.263-298.

${ }^{15}$ LUKÁS, P. Fatigue Crack Nucleation and Microstructure. In: Metals Handbook, v.19, $10^{\mathrm{a}}$ ed., p. 96-109.

16 FRANKLIN, A.W., HESLOP, J., SMITH, R.A. Some metallurgical factors influencing the thermal-fatigue resistance of wrought nickel-chromium-base hightemperature alloys. Journal of the Institute of Metals, v.92, 1963-64, p.313-322.

17 BROEK, D. Mechanisms of fracture and crack growth. In: BROEK, D. Elementary engineering fracture mechanisms. Boston: Martinus Nijhoff, 1982. p.24-66.

${ }^{18}$ MEYERS, M.A., CHAWLA, K.K. Fatigue. In: MEYERS, M.A., CHAWLA, K.K. Mechanical behaviour of materials. New Jersey: Prentice-Hall, 1999. p.592-636. 
${ }^{19}$ BRESSERS, J. Fatigue: Mechanisms. In: Creep and fatigue in high temperature alloys. London: Applied Science, 1981. p.11-144.

${ }^{20}$ REZAI-ARIA, F., FRANÇOIS, M., RÉMY, L. Thermal fatigue of MAR-M509 superalloy - I, The influence of specimen geometry. Fatigue Fract. Engng. Mater. Struct, v.11, n.4, p.277-289, 1988.

${ }^{21}$ BECK, C.G., SANTHANAM, A.T. Effect of microstructure on the thermal fatigue resistance of a cast cobalt-base alloy, Mar-M509. In: SPERA, D.A., MOWBRAY, D.F., Thermal Fatigue of Materials and Components, ASTM STP 612, p.123140, 1976.

${ }^{22}$ BARON, H.G., BLOOMFIELD, B.S. Resistance to thermal stress fatigue of some steels, heat-resisting alloys, and cast irons, Journal of the Iron and Steel Institute, p.223-232, março 1961.

${ }^{23}$ WOODFORD, D.A., MOWBRAY, D.F. Effect of material characteristics and test variables on thermal fatigue of cast superalloys. A review. Materials Science and Engineering, v.16, p.5-43, 1974.

${ }^{24}$ DOBRZANSKI, L.A. et al. Comparison of the thermal fatigue resistance and structure of the 47CrMoWVTiCeZr16-26-8 hot-work tool steel with X40CrMoV5-1 type one, Journal of Materials Processing Technology, v.113, p.527-538, 2001.

25 GROSS, T.S. Micromechanisms of Monotonic and Cyclic Crack Growth. In: Metals Handbook,v.19, $10^{\mathrm{a}}$ ed., p.42-60.

${ }^{26}$ MCMAHON, C.J., COFFIN, L.F. Mechanisms of damage and fracture in hightemperature, low-cycle fatigue of a cast nickel-based superalloy, Metallurgical Transactions, v.1, p.3443-3450, dez 1970. 
${ }^{27}$ SEHITOGLU, H. Thermal and Thermomechanical Fatigue of Structural Alloys. In: Metals Handbook, v.19, $10^{\mathrm{a}}$ ed., p.527-556.

${ }^{28}$ STARLING, C.M.D., BRANCO, J.R.T. Thermal fatigue of hot work tool steel with hard coatings, Thin Solid Films,v.308-309, p.436-442, 1997.

${ }^{29}$ LI, G., XIANGSZHI, L., WU, J. Study of the thermal fatigue crack initiation life of H13 and H21 steels, Journal of Materials Processing Technology, v. 74, p.2326, 1998.

30 FORREST, P.G., ARMSTRONG, K.B. Investigation of the thermal fatigue behaviour of nickel-chromium-base alloys by strain cycling tests, Journal of the Institute of Metals, v. 94, p.204213, 1966.

${ }^{31}$ HASSELMAN, D.P.H. Unified theory of thermal shock fracture initiation and crack propagation in brittle ceramics. Journal of the American Ceramic Society, v.52, n.11, p.600-604, nov/1969.

${ }^{32}$ SPERA, D.A. What is thermal fatigue?. In: SPERA, D.A., MOWBRAY, D.F., Thermal Fatigue of Materials and Components, ASTM STP 612, p.3-9, 1976.

${ }^{33}$ GLENNY, E. The influence of specimen geometry on thermal-fatigue behaviour, In: INTERNATIONAL CONFERENCE ON THERMAL AND HIGH-STRAIN FATIGUE, London, 1967, p. 346-363.

${ }^{34}$ GLENNY, E.; TAYLOR, T.A. A study of the thermal fatigue behaviour of metals - The effect of test conditions on nickel-base high-temperature alloys. Journal of the Institute of Metals, v.88, p.449-461, 1959-60.

35 LEE, S. et al. Correlation of Microstructure and Fracture Toughness in Three High-Speed Steel Rolls. Metallurgical and Materials Transactions, v. 28A, p. 123134, janeiro 1997. 
${ }^{36}$ BHATTACHAR, V.S. Thermal fatigue behaviour of nickel-base superalloy 263 sheets. International Journal of Fatigue, v. 17, n. 6, p.407-413, 1995.

37 DIAS, A. et al. Mechanism of crack initiation by thermal fatigue and crack propagation in the case of hot rolling rolls, Engineering Materials Advisory Services, 1982, p. 662-671.

${ }^{38}$ LIEURADE, H.P. et al. Experimental simulation and theoretical modelling of crack initiation and propagation due to thermal cycling, High Temperature Technology, v. 8, n. 2, p.137-145, maio 1990.

39 LI, G. et al. The nucleation and propagation of a thermal fatigue crack in 4Cr2NiMoV steel, Journal of Materials Processing Technology, v. 100, p. 63-66, 2000 .

${ }^{40}$ GREEN, D., MUNZ, D. Thermal fatigue crack growth experiments on austenitic steel plates, International Journal of Pressure Vessels \& Piping, v. 65, p. 369-378, 1996.

41 JEAN, S. et al. Na investigation on heat checking of hot work tool steels. In: INTERNATIONAL CONFERENCE ON TOOLING, 5, Leoben-Austria, set/out 1999. Anais. Austria: Institut für Metallkunde und Werkstoffprüfung, 1999. p. 185193.

${ }^{42}$ BOCCALINI, M. Jr., GOLDENSTEIN, H. Solidification of high speed steels. International Materials Reviews, v.46, n.2, p.92-115, 2001.

43 WU, H.Q. et al. Solidification of multi-alloyed white cast iron: type and morphology of carbides. AFS Transactions, v.104, p.103-108, 1996. 
44 HWANG, K.C., LEE, S., LEE, H.C. Effects of alloying elements on microstructure and fracture properties of cast high speed steel rolls. Part I: Microstructural analysis. Materials Science and Engineering, v.A254, p.282-295, 1998.

${ }^{45}$ HASHIMOTO, M. et al. Development and Application of High-Speed Tool Steel Rolls in Hot Strip Rolling. Nippon Steel Technical Report, n.66, p. 82-90, julho 1995.

${ }^{46}$ WISNIEWSKI, A. et al. Role of carbide-forming elements on the thermal fatigue behaviour of a steel grade used for hot-rolling mill rolls. Mém. Études Sci. Rev. Mét, p.356-63, june 1991.

${ }^{47}$ ERICKSON, L.C., HOGMARK, S. Analysis of banded hot rolling mills, Wear, v. 165, p.231-235, 1993.

${ }^{48}$ COLÁS, R. et al. Damage in hot rolling work rolls. Wear, v.230, p. 56-60, 1999.

${ }^{49}$ LUNDBERG, S. Evaluation of deterioration mechanisms and roll life of different roll materials, Steel Research, v.64, n.12, p.597-603, 1993.

${ }^{50}$ KANG, Y.J.et al. Effects of carbon and chromium additions on the wear resistance and surface roughness os cast high-speed steel rolls, Metallurgical and Materials Transactions, v.32A, p.2515-2525, out 2001.

${ }^{51}$ PARK, J.W., LEE, H.C., LEE, S. Composition, microstructure, hardness and wear properties of high-speed steel rolls, Metallurgical and Materials Transactions, v.30A, p.399-409, fev 1999.

${ }^{52}$ RYU, J.H., RYU, H.H. Correlation of rolled-in defects in IF steels and the thermal fatigue properties of the hot strip mill work rolls. In: MWSP CONFERENCE PROCEEDINGS, 42, ISS-AIME, 2000, v.XXXVIII, p. 223-231. 
${ }^{53}$ BOCCALINI, M. JR.et al. Effects of vanadium content and cooling rate on the solidification of multi-component white cast iron. In: THE SCIENCE OF CASTING AND SOLIDIFICATION, Romênia, maio 2001. Anais. Romênia: Lux Libris, 2001. p.393-398.

${ }^{54}$ Desenvolvimento da produção de cilindros de aço rápido para laminação de tiras a quente- Relatório parcial. Processo FAPESP 1997/2427-7.

55 SERANTONI, C.R. Efeito dos Teores de Molibdênio e Tungstênio sobre a Solidificação dos Aços Rápidos para Cilindros de Laminação a Quente, Relatório de Estágio, Laboratório de Fundição do Instituto de Pesquisas Tecnológicas do Est. de S. Paulo- IPT, dez 2000.

${ }^{56}$ BOCCALINI, M. JR.et al. Effects of vanadium content and cooling rate on the solidification of multi-component white cast iron. In: THE SCIENCE OF CASTING AND SOLIDIFICATION, Romênia, maio 2001. Anais. Romênia: Lux Libris, 2001. p.393-398.

${ }^{57}$ Desenvolvimento da produção de cilindros de aço rápido para laminação de tiras a quente- Relatório parcial. Processo FAPESP 1997/2427-7.

${ }^{58}$ PPM2OOF, versão 1.1.18. Internet: NIST, 2001.

${ }^{59}$ ABAQUS, versão 5.7. ABAQUS, Inc.

60 National Institute of Standards and Technology - NIST. Washington, DC. Apresenta dados técnicos e científicos. Disponível em: $<$ http://srdata.nist.gov/gateway $>$. Acesso em 23 de julho. 2003. 
${ }^{61}$ Automation Creations, Inc. (ACI), MatWeb. Blacksburg VA. Apresenta dados de

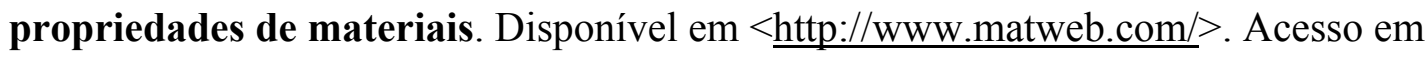
23 de julho. 2003.

${ }^{62}$ BROECKMANN, C.; PYAZALLA-SCHIECK, A. Microstructural aspects of failure in particle reinforced metal matrix composites. Computational Materials Science, v.5, p.32-44. 1996.

${ }^{63}$ HALFORD, G. R. Low-cycle thermal fatigue. In: HETNARSKI, R. B. Thermal stresses II. New York: North-Holland, 1987. p.329-428.

${ }^{64}$ DOWLING, N. E. Fatigue crack growth. In: DOWLING, N. E. Mechanical behavior of materials. New Jersey: Prentice-Hall, 1999. p.448-558.

${ }^{65}$ HAHN, G. T. The influence of microstructure on brittle fracture toughness. Metalurgical Transactions A, v. 15, p.947-960, jun 1984.

${ }^{66}$ FISCHMEISTER, H. F.; OLSSON, L. R. Fracture toughness and rupeture strengh of high speed steels. In: INTERNATIONAL CONFERENCE ON CUTTING TOOL MATERIALS, Ft. Mitchell, setembro 1980. Anais. Ft. Mitchell: Metals Park, Ohio: The Society, 1980. p.111-131.

${ }^{67}$ BERNS, H. Comparison of wear resistant MMC and White cast iron. Wear, v.254, p. 47-54, 2003.

${ }^{68}$ DOWLING, N. E. Fatigue crack growth. In: DOWLING, N. E. Mechanical behavior of materials. New Jersey: Prentice-Hall, 1999. p.448-558. 